\title{
THE INTENSIVE CONTROVERSY ON CHINESE HISTORICAL PHONOLOGY: REFUTATION OF THE LIQUID MEDIAL FOR DIVISION-2 IN OLD CHINESE
}

\author{
Jingyi Gao \\ Beijing International Studies University
}

\begin{abstract}
The present paper reports the intensive controversy on Chinese historical phonology that broke out in 2002. After sorting through over 150 Chinese papers on the intensive controversy by the Sino-linguists' side and the descriptivists' side, the present study suggests that we should investigate a history of the new hypotheses, and discuss them in a logical order. The hypothesis of the liquid medial for division-2 in OC of the descriptivists' side is refuted with philological arguments and a negative control of comparative evidence. The hypothesis of the vocalic medial for division-2 in OC of the Sino-linguists' side is supported with Sino-Vietnamese and Sino-Uralic comparative evidence. Using etymological methods, the present study has identified nine (9) Sinitic and Uralic shared etymologies. Four (4) Shennong (Sino-Uralic) etymologies belong to a rhyme correspondence. Five (5) Shennong (Sino-Uralic) etymologies belong to another rhyme correspondence. These two (2) regular sound correspondences validate the etymological connections between Sinitic and Uralic.
\end{abstract}

Keywords: academic controversy, academic war, Chinese historical phonology, Old Chinese, division-2 (division-II, div. II), liquid medial, vocalic medial, Sino-Tibetan, SinoVietnamese, Sino-Uralic, regular sound correspondence

DOI: https//doi.org/10.3176/tr.2021.1.07

Received 3 November 2020, accepted 18 December 2020, printed and available online 10 March 2021

\section{Introduction}

The liquid medial for division-2 in Old Chinese (OC) (a.k.a. Archaic Chinese) reconstruction has been claimed since Yakhontov (1960, Jaxontov $\left.{ }^{1} 1963 *_{-1-}\right)$. This

1 Cyrillic alphabets are transliterated according to the chart in Comrie and Corbett (1993: xii-xiii). 
claim has been advanced by Pulleyblank (1962*-1-) and Lǐ F. ${ }^{2}(1971$ *-r-), and then favored and applied by most ${ }^{3}$ Western scholars (e.g. Schuessler (1974b [external comparison to *-r-]; 1987-DEZC: 2, 2007-EDOC: 82, 2009 [reconstruction with *-r-]); Bodman 1980, 1985 [external comparison to *-1-/-r-]; Coblin 1986 [external comparison to *-r-]; Norman 1988: 65 [handbook with *-r-]; Starostin 1989: 329, Baxter 1992: 258, Sagart 1999: 11 [reconstructions with *-r-]; Handel 2002, 2009: 181 [external comparison to *-r-, with modification *r-]; Baxter and Sagart 2014 : 213 [reconstruction with *-r-]; Jacques 2015 [external comparison to *-r-]; Hill 2019: 173 [handbook with *-r-]) and most Chinese scholars with a descriptive linguistic orientation (e.g. Dīng B. 1978 [on *-r-]; Gong H. 1980, 1995 [external comparison to *-r-]; Zhèng-zhāng 1987, 2003a: 169 [reconstruction with *-r-]; Zhāng S. and Yáng J. 1987: 133, Yáng J. 1996: 148, Pān W. 2000: 289, Mài Y. 2009: 114 [handbooks with *-r-]) who form a descriptivists' side (called “材料派 "the materials party” in Pān W. 2005a) (see Appendix 1 for more monographic titles). However, this hypothesis is not accepted by the vast majority of Sino-linguists and Sino-philologists who form

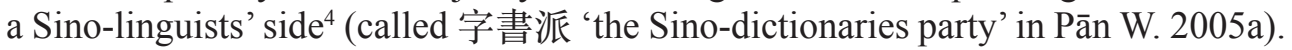
The Sino-linguists' side follows the view of Wáng Lì.

Wáng Lì 王力 (1900-1986), a landmark figure in Sino-linguistics, reconstructed (Wáng L. 1957) the vocalic medial *-e-/-o- $\left(*_{-}\right.$-e-, or *-o- for its 合口 labialized+ realization) for division-2 rhymes ${ }^{5}$ in OC. He insisted on it still in his elderhood (e.g. Wáng L. 1985: 50) ${ }^{6}$. The OC reconstruction of Wáng Lì (henceforth OC-W) has been favored and applied by most Chinese scholars with a philological orientation (e.g. Guō X. 1986 [reconstruction with *-e-/-o-, enlarged new edition 2010]; Chén F. and

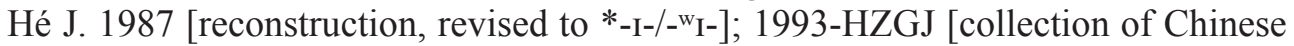
pronunciations including $\mathrm{OC}-\mathrm{W}]$; see Appendix 1 for more monographic titles).

2 There are too many Chinese publications by different authors but with the same surnames. A referenced author name of a Chinese publication includes an initial of the author's given name unless the surname already contains two morphemes.

3 There are also few Western scholars who have more methodological concerns and reject at least some general results of some scholars in this line, e.g. William G. Boltz $(1979,1993,2002)$ and Christoph Harbsmeier (2016).

${ }^{4}$ Both sides claim that their studies are 中國語言學 'China language science' in Chinese, or 'Chinese linguistics' in their own English. In fact, the studies of the Sino-linguists' side follow the two-thousand-year-old tradition of the language science developed in China with limited imports from the [Western] descriptive linguistics (e.g. the phonetic transcriptions). These studies should be called Sino-linguistics 中方語言學. The studies of the descriptivists' side have worked on the results of Sino-linguistics but are applying Western linguistic methods as much as possible. These studies should be called linguistics on Chinese 西方語言學用於漢語. They are comparable to Sinomedicine 中醫 and [Western] medicine in China 西醫在中國.

5 A rhyme is morphophonological. It can also be the - $\mathrm{VCv}$ part of a $\mathrm{CVCv}$ morpheme (where the small $\mathrm{v}$ stands for an unstressed vowel). A rime is phonological and phonetical. It must be the -VC part of a CVC syllable.

6 The gap between the two sides deepened since that Wáng L. (e.g. 1985: 23-25) did refute the consonant cluster claim of Karlgren (1923-ADCSJ), but did not refute the liquid medial claim of Yakhontov (1960). These two claims are not fundamentally identical. It was more problematic that Yakhontov (1960, Jaxontov 1963) did not mention Wáng L. (1957)'s solution for division-2 at all. It can be counted that the two sides have gone to separate studies since the 1950s. 
Sino-linguists have sound academic arguments to reject the liquid medial; although their arguments remained unpublished until the intensive controversy on Chinese historical phonology between the two sides broke out in China.

On December $8^{\text {th }} 2001$, Tsu-lin Mei 梅祖麟 (born in 1933), a senior leader of the descriptivists' side, professor emeritus at Cornell University, gave a keynote address presentation entitled "Chinese historical phonology with special Chinese characteristics 有中国特色的汉语历史音韵学” at a conference in Hong Kong. He claimed: (1) "[The OC reconstruction of Wáng Lì cannot be included in the mainstream.] 王力的上古音不能列入主流” (Méi Z. 2002: 224); (2) “[Should the Zhāng-Huáng school be counted as linguistics with special Chinese characteristics? Certainly not, it is not linguistics at all.] 章黄学派算不算有中国特色的语言学? 当然不是一一因为它根本不是语言学” (Méi Z. 2002: 229). The first claim aimed at Wáng Lì and his Peking school of Chinese historical phonology. The second claim aimed at the Zhuang-Huang school of Chinese philology, to which the vast majority of Chinese traditional philologists belong. In April 2002, Mei's presentation text was posted on the web forum of Peking University; it was hotly discussed. In the summer, Guō Xī-liáng 郭錫良 (born in 1930), a senior leader of the Sino-linguists' side, professor emeritus at Peking University, started reacting with a presentation entitled “[A few problems in Chinese historical phonology] 历史音韵学研究中的 几个问题” at three conferences in Nanchang, Urumqi and Shijiazhuang. His main themes are: (1) the methodology of Wáng Lì is sound; (2) refutation of consonant clusters in OC; (3) caveats to morphological changes in OC; (4) refutation of a few Sino-Tibetan comparisons.

In June 2002, Mei's presentation was published as a journal paper (Méi Z. 2002) in the Journal of Chinese Linguistics / 中国语言学报 'China Linguistics Journal' based in Berkeley (moved to Hong Kong in 2008). In September 2002, Guō's presentation was published as a journal paper (Guō X. 2002) in the journal 古汉语研 究 'Research on Ancient Chinese Language' based in Changsha. These two formal publications marked the official start of the intensive controversy. Since then, the two sides have critically argued about each other's academic results, methodological problems and publication errors; over 150 Chinese papers have been published on the controversy, directly or indirectly (see Appendix 2. It includes replies to Méi Z. 2002 or Guō X. 2002, replies to replies, refutations and pro or con comments, thematic papers on methodology and academic history containing mainly one's own side. Papers with only errata without methodological arguments are not counted).

The intensive controversy is actually caused by the fact that the two sides have ignored each other's academic results for many decades. The Sino-linguists' side did not refute each new hypothesis of the descriptivists' side in time thus had to refute them together. Sino-linguists were mobilized to write papers to refute the claims of the descriptivists' side. It is not an effective strategy. We should investigate a history of the hypotheses of the descriptivists' side, and discuss the hypotheses in a logical order.

Major different opinions of OC reconstruction authors are given in Table 1. We may see that a shared characteristic feature of the descriptivists' side (Pulleyblank 
Table 1. Major different opinions of OC reconstruction authors $(\bullet-$ yes, $\bigcirc-$ no)

\begin{tabular}{|c|c|c|c|c|c|c|c|}
\hline & $\begin{array}{l}\text { "mainly } \\
\mathrm{crc}\end{array}$ & $\begin{array}{l}\text { "Cc- } \\
\text { initials }\end{array}$ & $\begin{array}{l}\text { "liquid coda } \\
\text { for r.g. 歇微 }\end{array}$ & $\begin{array}{l}"-2 / \mathrm{x} \mid \mathrm{h} / \mathrm{s} \\
\text { for tone-B|C }\end{array}$ & $\begin{array}{l}\text { "liquid medial } \\
\text { for division-2 }\end{array}$ & $\begin{array}{l}\text { "the six } \\
\text { vowels }\end{array}$ & $\begin{array}{l}\text { coda "-r } \\
\text { for some -n }\end{array}$ \\
\hline Karlgren 1934, 1954, 1957 & $\bullet$ & $\bullet$ & $\bullet$ & $\circ$ & $\circ$ & $\circ$ & $\circ$ \\
\hline Wáng L. 1957, 1980a, 1985 & 0 & 0 & 0 & 0 & 0 & 0 & 0 \\
\hline Pulleyblank 1962, 1965, 1977-8 & $\bullet$ & $\bullet$ & $\bullet$ & $\boldsymbol{\bullet}_{(*-2 \mid-s)}$ & - (with caveat) & 0 & 0 \\
\hline Lì F. 1971 & $\bullet$ & $\bullet$ & $\bullet^{(1)}$ & $\bullet(*-x \mid-1)$ & $\bullet$ & 0 & ○ \\
\hline Schuessler 1974a,b, 1987-DEZG, 2009 & $\circ$ & $\bullet$ & $\bullet / o^{(2)}$ & $\boldsymbol{\bullet}_{(*-2)-\mathrm{h})}$ & - & $\bullet$ & o \\
\hline Dìng B. $1978,1979,1981,2015$ & $\bullet$ & $\bullet$ & $\bullet$ & $\mathrm{O}_{(1981-)}$ & $\bullet$ & $\circ$ & $\circ$ \\
\hline Guō X. 1986, 2010 & 0 & 0 & 0 & 0 & 0 & 0 & 0 \\
\hline Zhèng-zhāng 1987, 1992, 2003a & O & $\bullet$ & $\bullet_{(1992-)}$ & $\boldsymbol{\bullet}_{(*-2 \mid-5)}$ & - & $\bullet$ & o \\
\hline Starostin 1989 & 0 & $\bullet$ & $\circ$ & $\bullet_{(*-2-h)}$ & $\bullet$ & $\bullet$ & $\bullet$ \\
\hline Hé J. 1991 & 0 & $o^{(3)}$ & 0 & 0 & 0 & 0 & 0 \\
\hline Baxter 1992 & 0 & $\bullet$ & $\circ$ & $\boldsymbol{\bullet}_{(*-31-s)}$ & $\bullet$ & $\bullet$ & $\circ$ \\
\hline Baxter \& Sagart 2014 & $\circ$ & $\bullet$ & ० & $\boldsymbol{\bullet}_{(*-2 \mid-s)}$ & $\bullet$ & $\bullet$ & $\bullet$ \\
\hline Jīn L. 2002, 2013 & ० & $\bullet$ & $\bullet_{(*-\mathrm{r})}$ & $\boldsymbol{\bullet}_{(*-21-s)}$ & $\bullet$ & $\bullet$ & $\left.\boldsymbol{\bullet}_{\text {(but }} *_{-1}\right)$ \\
\hline Gāo J. 2008, 2014, Gao 2014, 2020b & $\circ$ & $\mathrm{O}^{(4)}$ & $\bullet$ & $\bullet_{(*-\mathrm{X} \backslash-\mathrm{S})}$ & 0 & $\circ$ & 0 \\
\hline
\end{tabular}

1962, 1977-8; Lǐ F. 1971; Schuessler 1974a,b, 1987-DEZC, 2007-EDOC, 2009; Dīng B. 1978, 1979, 1981, 2015; Zhèng-zhāng 1987, 1992, 2003a, 2013a,Zhengzhang 2000; Starostin 1989; Baxter 1992; Baxter and Sagart 2014; Jīn L. 2002, 2013) is the liquid medial for division-2. There are internal differences among the authors of the descriptivists' side, but they all accept the liquid medial. The Sino-linguists' side (Wáng L. 1957, 1980a,b; Guō X. 1986, 2010; Hé J. 1991) is very conservative, has not accepted any hypothesis from the descriptivists' side. Gāo J. (2008, 2014, Gao 2014, 2020b) is neutral, closer to the Sino-linguists' side, whereas he has accepted two hypotheses from the descriptivists' side.

We find that the hypothesis of liquid medial reconstruction in $\mathrm{OC}$ is one of the most fundamental hypotheses which should be refuted. Besides academic translations, explanations and table demonstrations of previously published counterarguments from the Chinese papers, we add a negative control ${ }^{7}$ to refute this hypothesis. We demonstrate Sino-Vietnamese and Sino-Uralic comparative evidence to support the hypothesis of vocalic medial reconstruction in OC.

7 Scientific experiments are always performed with controls to obtain reliable results. A positive control is a control group in an experiment that uses a treatment that is known to produce results. A negative control is a control group in an experiment that uses a treatment that is not expected to produce results. 
Previous versions of this paper have encountered many anonymous referees. Four of them (marked as Referee $\mathrm{A} / \mathrm{B} / \mathrm{C} / \mathrm{D}$ ) are specialists in OC. Their critical comments are answered in the present version. We thank Referee A for the helpful comments and suggestions.

Before the first peer review procedure, Section 3.5 and Section 4 involving the Sino-Uralic comparisons were deleted according to valuable suggestions of a board member of a journal. We do also think so that it is enough to accomplish a paper with the first sections without the reinforcement from the Sino-Uralic side. However, the referees have questioned the originality of those versions: "This paper reviews data and opinion related to the *-r- theory taken from a range of past work which, while largely published in mainland China, is nonetheless readily accessible to specialists the world over" (Referee C). Our concern is: The data and opinions published in mainland China have, so far, not been answered nor reported internationally. If you do not answer them and refuse to report them in English, you make a vicious circle that is not academic. In the present version, we have enlarged the first sections and added the last sections back.

\section{Materials and methods}

The present paper is a philological and etymological study. The Sinitic, TibetoBurman and Uralic etymologies (etyma) are studied and compared.

Sinitic etyma are guided by Chinese etyma (DOMs) that are historically attested glyphs. Their historical glosses are cited from the first two Chinese classical dictionaries (121-SW; 543-YP). Their historical phonological features are cited from the work 1161-YJ with reference to 1008-GY. A transcription of the phonetic values in 1161-YJ is given according to Appendix 1 in Gao (2020b). Their other attested equivalents including contemporary forms and glosses are represented by Mandarin (Beijing Yan) (written in Hanyu Pinyin including non-simplified forms), Cantonese (Guangzhou Yue) (written in Jyutping) and Minnan (Taipei Min) (written in Tâi-lô). English glosses are made in the present study. Historically attested OC rhymes of the etyma are given according to Zhōu Z. (1966), Wáng L. (1980a), Chén F. and Hé J. (1987) and Guō X. $(1986,2010)$ (in case of inconsistencies, category up to Wáng L. 1980a, glyph allocation up to Zhōu Z. 1966). Reconstructed phonetic values of the rhymes are made according to Appendix 2 in Gao (2020b).

Reconstructed forms are added only for reference reasons. All the attested forms are compared instead of trusting the phonetic and semantic details of reconstructions, because the reconstructions are always subject to changes depending on [newly] compared attested linguistic data. Two OC reconstructions are listed: 1) OC-W according to Wáng L. (1980a, modifications up to Wáng L. 1985); 2) OC-Z according to Zhèng-zhāng (2003a, 2013a). For a better comparison, their signs for aspiration are unified to the sign $/ \mathrm{h} /$; their signs for long vowel are unified to the sign $/: /$. Other reconstructions are cited from the direct references without modification. 
Tibeto-Burman etyma are based on the comparative works Benedict (1972) and Matisoff (2003). Uralic etyma are based on the etymological dictionaries 1988-UEW and 2001-SSA (of Uralic languages, SamilLappish North/Lule/Inari/Skolt/Kildin equivalents up to 1989-YSaS; North Sami forms are adjusted according to 1989SSS). Non-English glosses are translated into English in the present study. Some modifications (adding or deleting equivalents) are made and remarked.

In addition to the aforementioned sources, etymological equivalents suggested by other scholars are checked according to some additional etymological or comparative works, e.g. 1996-CV5ST and 2007-EDOC. Refutations of previously claimed etymological equivalents are given in footnotes.

Proto-Sinitic, also known as Proto-Chinese, cannot be compared because it is only a theoretical notion without reconstructed results. Proto-Sino-Tibetan cannot be compared because it is a hypothetical notion without a sufficient amount of etyma representing a sufficient number of the languages in question. Many scholars (e.g. Shī X. 2000, 2007; Huáng S. 2005; Zhang et al. 2019) are still comparing only Tibetan, Burmese or another Tibeto-Burman branch to Sinitic. The works Benedict (1972) and Matisoff (2003) have compared more "Sino-Tibetan languages", whereas many comparisons do not touch Sinitic. The work 1996-CV5ST compares only five "Sino-Tibetan languages": Sinitic, Tibetan, Burmese, Jingpho\Kachin and Mizo Lushai, whereas still many comparisons do not touch Sinitic. Etyma without Sinitic equivalents cannot be labeled as 'Sino-Tibetan'. Etyma with equivalents only in a Tibeto-Burman branch and Sinitic may be non-genetically diffused (loaned/ borrowed) from Sinitic or the Tibeto-Burman branch. There is a website called "The Sino-Tibetan Etymological Dictionary and Thesaurus" (https://stedt.berkeley.edu), whereas its content is so far a thesaurus (book of synonyms, collection of X-English dictionaries) rather than an etymological dictionary. This is the current situation of the comparative studies between Sinitic and Tibeto-Burman. Moreover, the SinoTibetan hypothesis has been successively criticized (Miller 1974; Beckwith 2002, 2006, 2008; Hé J. 2004; Gěng Z 2005; Guō X. 2008, 2010: 21; Zhāng M. 2012, 2013, 2014; Qú A. and Jìn S. 2013). Besides, there are hypotheses for the multiple origins of Sinitic (Lǐ B. 1990; Schuessler 2003). In sum, the notion Sino-Tibetan cannot be considered as a certain language family that includes or represents Sinitic.

Etymological equivalents (compared words) are given in orthographies or transcriptions. Equivalents in Western alphabets are given in boldface if they are found in official languages covered by ISO 639-1. Equivalents in Roman alphabets are given in italics. IPA-based transcriptions are not given in italics. If a given equivalent is longer than one morpheme, the targeted morpheme is underlined (if certain). In successive data, dialectal and authorial variants are separated by a slash (/); grammatical variants are separated by a backslash ( () ; while lexical variants are separated by a comma (,).

Ancient and fully etymological Sinitic etyma are put in the solid brackets 【】 and labeled as DOM in tables. Ordinary Chinese terms are put in the blank brackets [】 or written without brackets. Unattested and reconstructed forms are marked with an asterisk $(*)$. Attested but phonologically realized forms based on ancient Sinolinguistic data (e.g. Chinese descriptions in rhyme tables and rhyme dictionaries) 
are marked with a blank star ( $\left.{ }^{(1)}\right)$. Double quotation marks ("“") are added when its target is quoted (on sentences) or not agreed (on forms and terms). Double arrows $(\Rightarrow$ or $\Leftarrow)$ indicate genetic diffusions. Single arrows $(\rightarrow$ or $\leftarrow)$ indicate non-genetic diffusions. The sign indicates that its target is a dependent (bound) morpheme (only denoted for Mandarin). In etymological results, a triangle sign $(\triangle$ ) marks that the referenced comparison is fundamentally correct while the details of equivalents are amended in the present study.

The etymological methods follow traditional etymology (cf. 1662-ELL, Lemon 1783, Rask 1818; Gāo J. 2008) and renewed etymology (cf. Gao 2012-3, 2014, 2017, 2018, 2019a, 2019b, 2020a, 2020b; Gāo J. 2014; Gao and Tender 2020).

\section{Discussion}

\subsection{Refutation of the fundamental arguments of liquid medial for division-2 in OC}

The hypothesis of liquid medial reconstruction in OC goes back to Yakhontov (1960, Jaxontov 1963). Yakhontov's (1960: 3-7) original hypothesis includes the following arguments (the original style is unchanged):

\#1) Syllables of the IInd division hardly ever begin with the consonant "l".

\#2) It should be noted that when one graphic group includes words with initial "l" and words with other initial consonants, the latter (if they do not contain the medial i or i) are mostly syllables of the IInd, and not of the Ist, division.

\#3) Comparison with other languages where 1 or $r$ correspond to the 1 in Chinese, provides evidence of the presence of 1 in Chinese syllables of the IInd division. E.g. 八 pwat (*plat) "eight" - Tibetan b-r-gyad; 百 pek (*plâk) "one hundred" - Tibetan b-r-gya; 馬 ma ${ }^{\text {II }}$ (mlâlI $)$ "horse" Burmese mrang"; 江 kång (*klong) "river" - Thai khlong "canal"; 甲 kap (*klap) "armour" - Tibetan khrab.

Of the Sino-linguists' side, three papers (Lǐ J. 2007; Cuī Y. 2007; Sūn Y. 2014) have focused on refuting this hypothesis.

Lí J. (2007: 11) has counted 22 xiesheng series (e.g. 來, 賴, 樂, 里, 立, 侖, 豊, 翏) with Middle Chinese (MC) initial 來 ${ }^{4} 1$ - phonetic component, altogether 212 Sinograms ${ }^{8}$ [called "words" in Yakhontov 1960]. 150 of them are read with the initial 來 " 1 - (來母字, 1-Sinograms), 62 of them are not read with the initial 來 "1- ( 非來母字, non-1-Sinograms). Of these 62 non-1-Sinograms, 6 belong to division-1, 18 to division-2, 34 to division-3, 4 to division-4.

He has also counted 23 xiesheng series (e.g. 各, 䖈, 处, 兼, 劦, 柬, 京, 处) without initial 來 1 - phonetic components but with initial 來 1 - turnouts, altogether 209 Sinograms. 84 of them are read with the initial 來 "1- (來母字, 1-Sinograms), 125 of them are not read with the initial 來 1 - (非來母字, non-1-Sinograms). Of these 125 non1-Sinograms, 19 belong to division-1, 30 to division-2, 48 to division-3, 28 to division-4.

8 The details of these Sinograms were not published in Lǐ J. (2007) but in Lǐ J. (2015: 300-329). 
He concludes: "There are altogether 187 non-1-Sinograms without the initial 來 1 - but related to the initial 來 " 1 - phonetic components [in which the descriptivists' side shall reconstruct ${ }^{*} \mathrm{Cl}$ - or ${ }^{*} \mathrm{Cr}-\mathrm{C}$. $25(13.3 \%)$ of them belong to division- 1,48 (26.1\%) of them to division-2, $82(43.6 \%)$ of them to division-3, $32(17.0 \%)$ of them to division-4. There are indeed more division-2 Sinograms than division-1 Sinograms, but there are even more division-3 Sinograms. Why could Yakhontov exclude division-3 and division-4 before his interpretation?" (Ľr J. 2007: 11, translated from Chinese) This reveals that Yakhontov's original argument \#2 "are mostly syllables of the IInd, [...], division" is incorrect.

Referee B (the most radical anonymous referee, apparently from the descriptivists' side) argues: "The author must have misunderstood something. A number of Division-3 and 4 rimes must be reconstructed with *-r-. *-r- is not only hypothesised for Division-2 rimes." No, we have not misunderstood anything. You have not understood that it is important to confirm whether Yakhontov's original arguments are correct. We will return to this issue later.

Cū Y. (2007: 22) has counted 417 division-2 Sinogram families, and found that only $15(3.6 \%)$ of them are related to other Sinograms having the initial 來 ${ }^{\text {in }} 1$. She deduces: If all the division-2 Sinograms are reconstructed as ${ }^{*} \mathrm{Cl}-\left[{ }^{*} \mathrm{Cr}-\right]$, the medial $*_{-1}\left[{ }^{*}\right.$-r- $]$ has vanished in more Sinograms with no trace left, it is illogical and invalid.

Referee C says: "These different claims [the counts of Lǐ J. (2007) and Cūi Y. (2007)] are very hard to reconcile." Here we explain. Their findings are in two different directions. Lí J. (2007) counts xiesheng series and then counts the four divisions. Cuī Y. (2007) counts only division-2 Sinograms and then examines the postulated shift *Cr- $>*^{*}$ - $>$ *1- (from OC medial *-r- to MC initial ${ }^{*} 1-$ ) which turns invalid in conclusion.

Cuī Y. (2007: 22) has listed some xiesheng series pairs consisting of a division-1 Sinogram and an initial 來 1 - Sinogram, in which the division-1 Sinogram cannot be explained as a later change, e.g. 处 絡, 悝 里, 濼/鮊/嚛 樂, 睔 侖, 飒 立. This reveals that Yakhontov's original argument \#2 "not of the Ist, division" is incorrect.

Referee B argues:

Her arguments do not seem to be flawless as well. For example, 处 has two Middle Chinese forms, Division-3 [ $\left.{ }^{[\hat{k}}\right] \mathrm{gjuwX}$ and Division-1 [ $\left.{ }^{[\boldsymbol{k}}\right] \mathrm{kæw}$, the

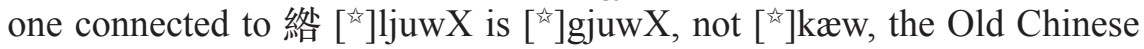
form is to be reconstructed with something like *grju (Division-3). This example shows unfamiliarity with Middle Chinese phonology.

This argument is not impactful. As long as a Sinogram has a division-1 form, you cannot ignore it. Nevertheless, the other form is of division-3, not your expected division-2.

Sūn Y. (2014: 124-125) has listed 52 division-2 Sinograms with the initial 來 江l-, e.g.【瀧, 犖, 礐, 爍, 濼, 潾, 顟, 翏, 摎, 冷, 醶, 磷】. It reveals that Yakhontov's original argument \#1 "syllables of the IInd division hardly ever begin with the consonant ' 1 '" is incorrect.

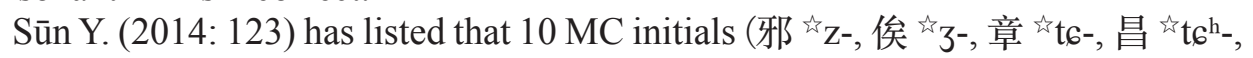




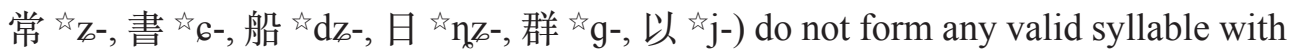

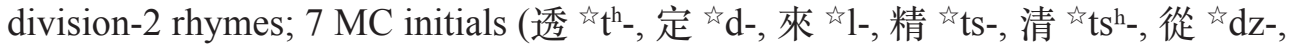
心 江-) form only 1-5 valid syllables with division-2 rhymes. He has asked: Why did Yakhontov pick only the initial 來 for an analysis towards $* \mathrm{Cl}-\left[{ }^{*} \mathrm{Cr}-\right]$ ?

So far, these crucial questions from the Sino-linguists' side have not been answered by the descriptivists' side in the Chinese academic world. The whole controversy has not been reported internationally.

Referee B complains:

I do not see how this observation is related to refuting *-r-. Let's agree that Middle Chinese 章母 [ [3] t6 comes from Old Chinese *t-, if there were Division-2, it would be reconstructed as *tr-, which yield a 知 initial. A “心 母二等” initial would be a 生母 *sr-. The distribution of Division-2 does not say anything about *-r-.

Referee D (another radical anonymous referee, apparently from the descriptivists' side) claims:

This shows that neither Sun nor the A[uthor](s) have grasped the beauty of Yakhontov's idea. [...] The case of 來 is special: the (almost complete) lack of division-2 words beginning in $\mathrm{MC}$ [ $\left.{ }^{\text {i }}\right] 1$ - is due to the fact that $\mathrm{OC}$ initial *r plus medial *-r- was not a possible onset. For that reason, the 來 initial is mostly absent from division 2 . Yakhontov focused on 來 because it made sense, on both distributional and phonetic grounds, that $\mathrm{MC}$ retroflexes go back to OC clusters of an apical plus 來.

They did not understand Sūn's point at all. Here we explain it more. This observation is related to refuting *-r-, because Yakhontov picked only the initial 來 ${ }^{\text {}} 1$ - to reconstruct $* \mathrm{Cl}-\left[{ }^{*} \mathrm{Cr}-\right]$. This observation reveals that it would be possible to pick, for example, the initial 群 ${ }^{\text {is }} \mathrm{g}$ - to reconstruct ${ }^{*} \mathrm{Cg}$-, the initial 邪 ${ }^{\text {th }} \mathrm{z}$ - to reconstruct $* \mathrm{Cz}$-, or the initial 心 ${ }^{\star} \mathrm{s}-$ to reconstruct $* \mathrm{Cs}-$, if Yakhontov's practice is ratified. In this way, the possibilities of consonant clusters will be out of control, therefore this ratification cannot be granted.

Referee $\mathrm{C}$ does not misunderstand but says:

The fact that 來 [i $\left.{ }^{3}\right] 1$ - (among others) is rare in Div. II, but not completely absent, is a challenge for *all* analyses, not just for *-r-. So again, the reader is left feeling that the author aims to assemble any and all facts which might speak against *-r- even when these facts defy consistent explanation on *any* approach.

We thank Referee C for acknowledging it, when Referee B and Referee D are trying to argue against it. Our main point is that it is a challenge for all consonantal analyses but not for vocalic analyses. Your side thinks of consonantal analyses by default, just because you believe in your "Sino-Tibetan language family" and you think OC could contain consonant clusters like Written Tibetan. Your belief is just a hypothesis. It cannot be used as a precondition in Sinitic studies.

We present Table 2 to help readers understand this section better.

Table 2 compares reconstructed results of OC-W of the Sino-linguists' side, 
and OC-L (Lǐ F. 1971), OC-Z, OC-B (Baxter 1992) and OC-BS (Baxter and Sagart 2014) of the descriptivists' side. The Sino-linguists' side treats the difference of divisions as vocalic medials. The results are very systematic. Sinograms with the same phonetic component are reconstructed with the same final. The " $1-$ interchange in the initial position should be explained with other factors, e.g. simply *C- $>$ in 1 . The descriptivists' side believes that OC contained consonant cluster initials or onsets as Written Tibetan (reconstructions with consonant clusters initials or onsets are shadowed in Table 2), thus all the 1 - interchanges should be reconstructed and explained within the onset position: ${ }^{*} \mathrm{C}-{ }^{*} \mathrm{Cr}-{ }^{*}{ }_{\mathrm{r}-}>{ }^{*} 1-$. However, Table 2 reveals that their expected systematic solution is not valid, because the 1 - interchange is not limited to division-2, thus many 1 - interchanges are not reconstructed and explained with the same solution (inconsistencies are marked in Table 2). They started to treat division-2 as a liquid consonant, since Yakhontov (1960) found that division-2 and a liquid initial could be in complementary distribution. This finding is incorrect. The descriptivists' side did not notice it, thus it has produced strange outcomes such as OC-L *Iramx and OC-Z *gr-re:m?. It has to be acknowledged that the liquid approach is wrong in its groundwork.

Table 2. Comparison of OC systems involving 1 - interchange

\begin{tabular}{|c|c|c|c|c|c|c|c|}
\hline & DOM & 1008-GY & OC-W & OC-L & OC-Z & OC-B & OC-BS \\
\hline \multirow[t]{4}{*}{ division-1 } & 【論】 & 盧昆切 & *luən & $* 1$ in & *nu:n & *c-run & $*[\mathrm{r}]^{\mathrm{s}} \mathrm{u}[\mathrm{n}]$ \\
\hline & 【睔】 & 胡本切 & *yuən & $* \mathrm{~g}$ w & $*$ guu:n? & *gun? & -- \\
\hline & 【拉】 & 盧合切 & *ləp & $*$ 田 & $*$ *nu:b & *c-rup & $*[r]^{\varsigma} \partial p$ \\
\hline & 【颯】 & 蘇合切 & $*_{\mathrm{s} p \mathrm{p}}$ & $*$ s $ə p$ & $*$ slu:b & $*$ sup & -- \\
\hline \multirow[t]{4}{*}{ division-2 } & 【變】 & 生患切 & *loan & *sruanh & $*_{\text {smro:ns }}$ & *srons & $*[$ s.r]on-s \\
\hline & 【蠻】 & 莫還切 & $*_{\text {moan }}$ & *mruan & *mro:n & *mron & ${ }^{*} \mathrm{~m}^{\mathrm{\varsigma}} \mathrm{ro}[\mathrm{n}]$ \\
\hline & 【醶】 & 力減切 & *leam & *Iramx & *gr-re:m? & $*_{c-\text { ram? }}$ & -- \\
\hline & 【䯬】 & 古斬切 & *keam & *kramx & *kre:m? & *krem? & ${ }^{*} \mathrm{Co} \cdot[\mathrm{g}]^{\mathrm{S}} \mathrm{r}[\mathrm{o}] \mathrm{m}$ \\
\hline \multirow[t]{4}{*}{ division-3 } & 【吏】 & 力置切 & $* \operatorname{li}_{\lambda}$ & $*[1] \mathrm{ghh}$ & $*_{\text {rus }}$ & ${ }^{*}$ c-rjos & *[r]ə?-s \\
\hline & 【使】 & 踈士切 & $* \int_{\underline{\lambda}}$ & $*$ srjagx & *sruu? & $*_{\text {srjə? }}$ & $*_{s-r o ?}$ \\
\hline & 【陸】 & 力竹切 & *link & $* 1 \mathrm{1j} 2 \mathrm{k}^{\mathrm{w}}$ & $* m \cdot r u g$ & $*_{c-\text { rjuk }}$ & *[r]uk \\
\hline & 【晆】 & 莫六切 & $*_{\text {minik }}$ & $* m j a k^{w}$ & *mug & $*_{\mathrm{mju}}$ & ${ }^{*} \mathrm{mr}[\mathrm{uk}]$ \\
\hline \multirow[t]{4}{*}{ division-4 } & 【禮】 & 盧啓切 & $*$ liei & $* \operatorname{lid} x$ & $*_{\text {ri }}$ ? & *c-rij? & $*[r]^{\mathrm{sij}} ?$ \\
\hline & 【體】 & 他禮切 & $* t^{\mathrm{ln}}$ iei & $* \operatorname{lidx}$ & $* \mathrm{r}^{\mathrm{h}} \mathrm{i}: ?$ & $*_{r i j}$ ? & $*_{\mathrm{r}}^{\mathrm{s}} \mathrm{ij} \mathrm{j}$ \\
\hline & 【荔】 & 郎計切 & $*$ liap & $*$ Iliabh & *ne:bs & $*_{c \text {-reps }}$ & $*[\mathrm{r}]^{\mathrm{s}} \mathrm{ep}-\mathrm{s}$ \\
\hline & 【協】 & 胡煩切 & *yiap & $*$ [ ]iap & * hile:b & *gep & $*[\mathrm{G}]^{]} \mathrm{ep}$ \\
\hline
\end{tabular}




\subsection{Refutation of $O C{ }^{*}-r$-by initial repeating reduplicative words}

Sūn Y. (2014: 120-122) has listed 23 OC 'initial ${ }^{9}$ repeating reduplicative words' $(\text { IRRW })^{10}$ that are made of a division-2 Sinogram and a non-division-2 Sinogram, e.g. 綿蠻 (詩·小雅·綿蠻); 震霖 (詩·小雅·信南山); 薢若 (爾雅·釋草); 鴶鶴 (爾 雅·釋鳥); 萧臀 (詩·秦風·莱臀). He has asked: If all the division-2 Sinograms are reconstructed ${ }^{*} \mathrm{Cl}-[$ or $* \mathrm{Cr}-]$, these words would be in ${ }^{*} \mathrm{C}-\mathrm{Cl}-\left[{ }^{*} \mathrm{C}-\mathrm{Cr}-\right]$ or ${ }^{*} \mathrm{Cl}-\mathrm{C}$ $\left[{ }^{*} \mathrm{Cr}-\mathrm{C}-\right]$ structure. How can they be initial repeating reduplicative words? ${ }^{11}$

We compile Table 3 to help readers understand this point better.

Table 3. Comparison of $\mathrm{OC}$ systems involving initial repeating reduplicative words

\begin{tabular}{|c|c|c|c|c|c|}
\hline IRRW & OC-W & OC-L & $\mathrm{OC}-\mathrm{Z}$ & OC-B & OC-BS \\
\hline 綿蠻 & *mian-moan & *mjian-mruan & *men-mro:n & *mjen-mron & -- \\
\hline 震霖 & *mek-mok & *mrik-muk & *mre:g-mo:g & *mrek-mok & -- \\
\hline 薢茩 & *ke-ko & *krig-kugx & *kre:-ko:? & *kre-ko? & -- \\
\hline 鴣鴝 & ${ }^{*}$ ket-kinuk & *krit-kjəkw & *kri:d-kug & *krit-kjuk & -- \\
\hline 粟澱 & *kiam-kea & *kiam-krag & *ke:m-kra: & *kem-kra & -- \\
\hline
\end{tabular}

When the different systems of OC reconstructions are applied to the initial repeating reduplicative words in $\mathrm{OC}, \mathrm{OC}-\mathrm{W}$ reconstructions are still initial repeating reduplicative words; the others are not, because they are interrupted by the liquid medial *-r- (shadowed in Table 3). The reason of this failure is not complex. The other authors did not notice such words in OC verses when they added the liquid medial *-r- to divison-2 Sinograms in their systems. Their motivation is comparing Tibeto-Burman rather than reading $\mathrm{OC}$ verses. Their enterprise cannot be granted.

Of the Sino-linguists' side, this is to date the most impactful and original argument against the liquid medial reconstruction. The author Sūn Yù-wén 孫玉文 (born in 1962) is a leader of the Peking school, professor at Peking University. His magnum opus (Sūn Y. 2000) has been introduced in English (see Behr 2002). Most scholars working on OC phonology have not particularly investigated such words in OC verses. This finding requires the author's high ability in both OC phonology and philology.

He has already excluded the extreme cases in which the initial repeating reduplicative words are made of two division-2 Sinograms, while the descriptivists'

9 Sino-linguistic term 聲紐/聲/紐 initial. It is mostly corresponding to an onset in Western linguistics. Their difference appears only in a few cases; e.g. $/ \mathrm{kw}-/$ is an onset but an initial $/ \mathrm{k}-/$ plus a medial /-w-/.

${ }^{10}$ Sino-linguistic term 雙聲聯綿詞: Disyllabic words in which the identical initial repeats, cf. English see-saw, flip-flop.

${ }^{11}$ A consonant initial plus a liquid must be analyzed as an initial of consonant cluster. Cf. /skr-/, /sk-/, /kr-/, /s-/, /k-/ and /r-/ are phonologically equal onsets and initials. A medial must be vocalic until the liquid medial hypothesis attempted to add the liquid. 
side would reconstruct $* \mathrm{Cl}-\mathrm{Cl}$ - [or $* \mathrm{Cr}-\mathrm{Cr}$-] (initial repeating). If the descriptivists' side will reconstruct $* \mathrm{Cl}-\mathrm{Cl}-[$ or $* \mathrm{Cr}-\mathrm{Cr}-]$ in all the initial repeating reduplicative words involving only one division-2 Sinogram, say 薢茩 as *kre:-kro:?, instead of OC-Z *kre:-ko:?, it means that they reconstruct *Cl- [or *Cr-] also for non-division-2 Sinograms. Their comparative basis, the liquid medial for division-2, is ruined by themselves.

Referee B argues:

For some of them, especially with a 侯 rime character, it is impossible to distinguish Division-1 from Division-2. Since there is simply no Division-2 in the rime. Therefore 芳 and 逅 probably had *-r-. Second, in SinoTibetan languages, IRRW do not necessarily repeat the whole onset, in a lot of cases, the main initial is reduplicated, and the medial or preinitials are omitted, see Xi[à]ng and Ch[é]n (2004) and L[à]i (2013). I do not see this as a major issue against *-r-.

For the first part, your argument is an assumption without attested evidence. We understand that you are claiming that $\mathrm{OC}$ divisions could be different to $\mathrm{MC}$ divisions. However, it is important that the $\mathrm{MC}$ divisions are attested preconditions. One can either follow the attested preconditions in full or reconstruct a whole system of OC divisions with full scale correspondences between OC and $\mathrm{MC}$ divisions. You follow the attested preconditions when they are of your expected division-2, but alter them when they are not of your expected division-2. This practice is incorrect.

For the second part, despite the validity of your "Sino-Tibetan language family", we consult the papers you mentioned. The paper Xiàng and Chén (2004) has listed five initial repeating reduplicative words involving both positive and negative deletion of the component -r-, -1- or -j-: 'mbu-mbro (+), ßru- $\beta$ гак (-), mbu-mbjis

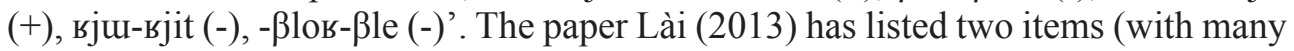
free variants): 'srǽm-sra (-) / srǽm-sru (-), zgrà-zgra (-) / zgrò-gra (-) / zgrò-zga (+) / zgrà-ga $(+)$ '. By seeing these words, we must suggest the deletion of the component $-\mathrm{r}-,-1-$ or $-\mathrm{j}-$ is conditioned by the length of initial. If the initial is long (mb-, zg-), the next consonantal component (mbr-, zgr-) can be omitted. If the initial is short ( $\beta-$, в-), the next consonantal component ( $\beta \underline{\mathbf{r}}-$, ьј-,,$\beta \underline{1}-)$ cannot be omitted. Because the OC initial in question is short, the next consonantal component cannot be omitted. Since it is omitted in your reconstruction, it is a major issue against *-r-.

Besides the shared mistake on the 侯 rime, Referee D argues against it but in a totally opposite direction:

With the other examples cited by the author(s): 震霖, 驞駍 and 萧澱, one should keep in mind the possibility of a doublet: the non-division-2 member of the disyllable had an $<\mathrm{r}>$ infix in the original pronunciation, but not in the reading that underlies Middle Chinese.

This argument is not valid. These words are attested since OC. If your $<r>$ infix was in OC but lost in MC, OC should use other Sinograms to write these words. You might suggest it was lost in OC but preserved in your "Proto-Sino-Tibetan". However, what evidence do you have for it apart from your theoretical presumption? There is no Sino-Tibetan comparative evidence for these words. 
In simple words, Referee B claims that '*kre:-ko:?' should be fine, while Referee D claims that there must be a sound change '*kre:-kro:? > *kre:-ko:?'. You do not even try to suggest a sound change *ke:-ko:? $>*$ kre:-ko:?. You attempt to rescue your liquid medial at any price. What prevents you from abandoning *-r- and considering OC-W *ke-ko? It is apparently only your faith in your 'Sino-Tibetan language family'. Unfortunately, you have not suggested any Tibeto-Burman word in the form of kre-ko or kre-kro to be compared to this Sinitic word.

\subsection{Refutation of Sino-Tibetan comparisons involving $O C *_{-} r$ -}

Fairly speaking, Yakhontov's argument \#3 "Comparison with other languages [...]" has not been effectively refuted. The Sino-linguists have argued that external comparisons in general can be invalid (e.g. Guō X. 2002: 6-8; 2003: 6-11; 2010: 21; Sūn Y. 2014: 119) with some examples, but without demonstrating how the comparisons involving OC *-r- are invalid. We would like to contribute detailed arguments to refute Yakhontov's argument \#3.

Basically, some of the external comparative evidence for OC *-r- are invalid. Yakhontov's two primary examples "[Sinitic] 八 [ $\left.{ }^{\star *}\right]$ pwat (*plat) 'eight' Tibetan b-r-gyad" and “百 [ $\left.{ }^{[}\right]$pek (*plâk) "one hundred" " Tibetan b-r-gya' have been disclaimed in Jin L. (2003) from the descriptivists' side. He discussed that the $b$ - part in these Tibetan words is an affix that does not belong to the target morpheme of the

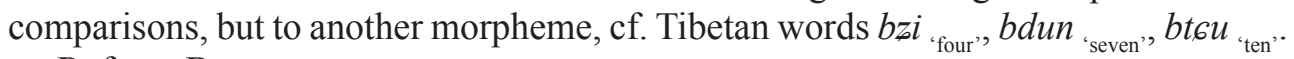

Referee B argues:

That the Tibetan $b$ - is a prefix does not mean that it cannot have correspondences in other Sino-Tibetan languages. Numeral prefixes can probably be reconstructed into Proto-Sino-Tibetan, it is not surprising that Chinese possesses some of their traces.

This argument is invalid. If you claim that Sinitic possesses the prefix $b$-, why is it not preserved in the Sinitic numerals four, seven and ten, but only in the Sinitic numerals eight and hundred? The match from the prefix $b$ - in Tibetan to the initial * $p$ - in Sinitic is apparently a chance resemblance.

Yakhontov's another primary example "[Sinitic] 江 [^]kång (*klong) 'river' Thai khlong "canal" " is refuted in a footnote in Section 4.

Generally, even if we assume that all the Sino-Tibetan comparisons of the descriptivists' side involving $\mathrm{OC} *$-r- are valid, their comparisons cannot support the postulated division correspondence 'Sinitic division- $2 \Leftrightarrow$ Tibetan/Burmese - $r-$ ', because their data fail to pass a negative control. In this negative control (see Table 4), ten non-division-2 etyma are observed, that they should NOT yield the hypothesized phonetic outcome $-r$ - in Tibetan and Burmese.

As shown in this negative control, the division-3 and division- 4 etyma do also yield the hypothesized phonetic outcome - $r$-. Although it has been suggested that 'the chóng-niǔ division-3 重紐三等' etyma should also contain *-r- (Pulleyblank 1962; Baxter 1977; Zhèng-zhāng 1987), it can explain only the outcome in line 3 【泣】, all the other outcomes cannot be explained. Handel's $(2002,2009)$ modification (including its following Zhang et al. 2019 application of the modification) of this 
Table 4. Postulated division correspondence negative control:

NEGATIVE \{Sinitic division-2 $\Leftrightarrow$ OC-Z -r- $\Leftrightarrow$ Tibetan/Burmese $-r$ (previously claimed Tibetan and Burmese equivalents from Gong 1980, 1995, up to Gong 1995)

\begin{tabular}{|c|c|c|c|c|c|}
\hline DOM & $1161-Y J$ & OC-W & OC-Z & Tibetan & Burmese \\
\hline \multirow{2}{*}{ 【霧】 } & division-3 & *mio & $*_{\text {mogs }}$ & rmugs-pa & $m r u^{A}$ \\
\hline & \multicolumn{3}{|c|}{ 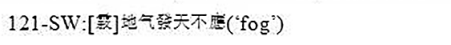 } & 'dense fog' & 'fog, mist, haze' \\
\hline \multirow{2}{*}{ 【立】 } & division-3 & *li & *rutb & 'khrab & rap \\
\hline & \multicolumn{3}{|c|}{ 121-SW:住也('stop') } & 'to strike' & 'to stand, to stop' \\
\hline \multirow{2}{*}{ 【泣】 } & division-3 & $* \mathrm{k}^{\mathrm{h}}$ iəp & $* \mathrm{k}^{\mathrm{l}} \mathrm{r}$ rurb & khrab-khrab & -- \\
\hline & \multicolumn{3}{|c|}{ 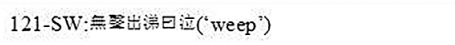 } & 'weeper' & \\
\hline \multirow{2}{*}{ 【胃】 } & division-3 & *yinat & $*_{\text {Guds }}$ & grod & -- \\
\hline & \multicolumn{3}{|c|}{ 121-SW: 旍渥地('stomach') } & 'belly, stomach' & \\
\hline \multirow{2}{*}{ 【友】 } & division-3 & *yị̂ə & $*_{\mathrm{G}}^{\mathrm{w}} \mathrm{UU} ?$ & grogs-po & -- \\
\hline & \multicolumn{3}{|c|}{ 121-SW:同志为友('friend') } & 'friend, companion' & \\
\hline \multirow{2}{*}{ 【越】 } & division-3 & *yinat & $*_{\mathrm{G}^{\mathrm{W}}}$ ad & 'grod & - \\
\hline & \multicolumn{3}{|c|}{ 121-SW: 爱地('go through') } & 'to go, to travel' & \\
\hline \multirow{2}{*}{ 【羽】 } & division-3 & * yịua & $*_{G}$ iva? & sgro & -- \\
\hline & \multicolumn{3}{|c|}{ 121-SW:烏長主也('feather') } & "large feather" & \\
\hline \multirow{2}{*}{ 【于】 } & division-3 & * yịua & $*_{\mathrm{G}^{\mathrm{w}} \mathrm{a}}$ & 'gro & krwa' \\
\hline & \multicolumn{3}{|c|}{ 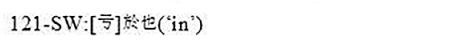 } & 'to walk, to go' & to proceed \\
\hline \multirow{2}{*}{ 【芋】 } & division-3 & *yịua & $*_{G^{w} \mathrm{a}}$ & gro-ma & - \\
\hline & \multicolumn{3}{|c|}{ 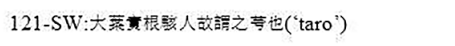 } & 'potato' & \\
\hline \multirow{2}{*}{ 【憐】 } & division-4 & $*$ lien & *re:1] & drin & rẫ̃- \\
\hline & \multicolumn{3}{|c|}{ 121-SW:哀也('sorrow') } & 'kindness, favor, grace' & 'love' \\
\hline
\end{tabular}

hypothesis is not relevant to this negative control. This modification postulates where the elements *r could be in some division-2 etyma (first as the prefix/preinitial $*_{r}$, then lost), it does not explain why there are also the elements $-r$ - in the putative non-Sinitic equivalents of Sinitic non-division-2 etyma. Finally, it is illogical to claim all the division-1, $-2,-3$, and -4 etyma may contain *-r-, because it contradicts the fundamental hypothesis of Yakhontov (1960) that only division-2 etyma should contain the liquid medial. 
This negative control failed; unexpected outcomes are left without explanation, therefore the postulated division correspondence 'Sinitic division-2 $\Leftrightarrow$ Tibetan/ Burmese - $r$-' is invalid. When the descriptivists' side demonstrated the postulated division correspondence with the expected results 'Sinitic division-2 $\Leftrightarrow$ Tibetan/ Burmese $-r-$ ', it was artificially selected. On the Sinitic side, only division-2 etyma were collected.

Referee B argues:

A number of Division-3 and 4 rimes must be reconstructed with *-r-. *-r- is not only hypothesised for Division-2 rimes. [...] You presuppose that *-rproponents agree that division-2 rimes in Chinese corresponds to TibetoBurman $-r$ - and vice versa. This is not true. Nobody ever made that claim.

This argument is lacking grounds of logic and mathematics. If you think TibetoBurman $-r$ - can widely appear without a mapping to Chinese division-2, then you cannot support Yakhontov's argument \#3 “Comparison with other languages where 1 or $r$ correspond to the 1 in Chinese, provides evidence of the presence of 1 in Chinese syllables of the IInd division", and you cannot reconstruct Chinese division-2 as *-r-. The vital problem is not that Tibeto-Burman - $r$ - does not correspond to Chinese division-2 in full, but that they may also correspond to other divisions in the way you claim for division-2.

We set: division-2 = X; division-3 = Y; division-4 = Z; division- $1=\mathrm{W}$. We know: $\mathrm{X} \neq \mathrm{Y} \neq \mathrm{Z} \neq \mathrm{W}$. In order to solve the values of $\mathrm{X}, \mathrm{Y}, \mathrm{Z}$ and $\mathrm{W}$, we must collect equations. Yakhontov (1960) collected five equations, say: $8 \mathrm{aX}=8 \mathrm{~b}(\mathrm{r}) ; 100 \mathrm{aX}=$ $100 \mathrm{~b}(\mathrm{r}) ; 81 \mathrm{aX}=81 \mathrm{~b}(\mathrm{r}) ; 9265 \mathrm{aX}=9265 \mathrm{~b}(\mathrm{r}) ; 910 \mathrm{aX}=910 \mathrm{~b}(\mathrm{r})$. It seemed perfect at first sight, thus the solution $X=r$ was claimed. The problem is that, according to the comparisons of Gong $(1980,1995)$, there are actually also equations, say $28 \mathrm{aY}=$ $28 \mathrm{~b}(\mathrm{r}) ; 303 \mathrm{aY}=303 \mathrm{~b}(\mathrm{r}) ; 94 \mathrm{aY}=94 \mathrm{~b}(\mathrm{r}) ; 9123 \mathrm{aY}=9123 \mathrm{~b}(\mathrm{r}) ; 974 \mathrm{aY}=974 \mathrm{~b}(\mathrm{r})$, thus the solution $Y=r$ can also be claimed, but it violates the condition $X \neq Y$. Therefore both the solutions $\mathrm{X}=\mathrm{r}$ and $\mathrm{Y}=\mathrm{r}$ are incorrect.

Referee D argues:

The author(s) wish to demonstrate that the reconstruction of a liquid medial in division-2, first proposed by Yakhontov in 1960, is incorrect. While Yakhontov's proposal was limited to division 2, the systems of Zhengzhang, Baxter, Starostin, Baxter-Sagart, at least, all allow medial -r- in division 3 as well, not just in division-3 chongniu but also in all division-3 retroflex initials and sometimes after grave initials, when evidence from xiesheng series or Chinese loanwords supports it. A central idea in the paper is that one cannot reconstruct -r- for division 2 because the arguments work just as well for division 3. This is only to be expected. Modern systems see a basic distinction between divisions 1, 2 and 4 on the one hand (type A) and division 3 (type B) on the other hand; division 3 contains 'iodized' versions of all the type A syllables, including division-2 (leaving aside the nature of 'iodization' here). So, yes, division-3 also includes words with medial -r-. Instead of trying to debunk Yakhontov's 60-year-old paper, the authors should have examined modern systems such as Zhengzhang's or Baxter-Sagart. 
The fundamental logics of Referee D and Referee B are very similar. They think their later modifications such as allowing *-r- to some division-3 (even also some division- 4 by Referee B) Sinograms can solve the problem. They have forgotten that it violates the fundamental logic of the liquid medial hypothesis. The four divisions are four categories. We have to find certain and different values for these four categories. Yakhontov (1960) started to suggest that the value of the category division-2 is a liquid. His basic argument is the exclusive correspondence between division-2 and the liquid. His logic is correct while his results are incorrect. If you claim that the exclusive correspondence is not necessary, your logic is incorrect, already. We say that $X=r$ is incorrect, because $Y=r$ and $X \neq Y$. Instead of correcting the value of $X$, you are proclaiming $X=Y$ (even also $X=Y=Z$ ). One day, would you proclaim $\mathrm{X}=\mathrm{Y}=\mathrm{Z}=\mathrm{W}$ ? Do you deny the four divisions or your logic? Ancient Chinese rhyme tables and Sino-philologists gave us the four divisions as four categories, and clarified they are different. You started your studies correctly with the rhyme tables as your primary preconditions. You cannot later deny or alter your primary preconditions when they do not satisfy your expectation. Once your groundwork is defective, all your constructions on it are falling.

Potentially, there will be a valid mapping if they claim a correspondence between division-2\&3 (all of division-2 and division-3) and the liquid medial (thus to reconstruct all of division- $2 *$-r-, all of division- $3 *$-rj-, and to reject all the SinoTibetan comparisons from Tibeto-Burman $-r$ - to Sinitic division-1\&4). Actually, they cannot claim so. It will result that too many (two out of four divisions) OC word roots contain *-r-. It is typologically unacceptable. Referee D has listed that they have tried to rearrange the four categories into two categories: division-1\&2\&4 and division-3. Therefore, this potentially valid mapping does not help them.

Referee $\mathrm{C}$ does not proclaim $\mathrm{X}=\mathrm{Y}$ but says:

The author argues that comparative evidence from Tibeto-Burman languages fails to support Old Chinese *-r- in Div. II syllables. However, it is already well-known that straightforward Chinese-to-TB onset or "medial" correspondences are difficult to identify by reference to *any* OC system. Furthermore, the author does not demonstrate that this material can support their argument for Wang Li's *-e-/*-o-.

We thank Referee C for acknowledging it, when Referee B and Referee D are trying to argue against it. Our main point here is the logic of negative control in scientific researches in general. Certainly, we do not demonstrate this Tibeto-Burman material can support Wang Li's vocalic medial hypothesis. We do not think these Sino-Tibetan comparisons are correct enough to be considered in Sinitic studies. We have Sino-Vietnamese and Sino-Uralic material to support Wang Li's vocalic hypothesis (Section 3.4 and 3.5).

Referee $\mathrm{C}$ and Referee $\mathrm{D}$ raise the issue of the diachronic changes of retroflex initials involving the medial *-r-. Referee $\mathrm{C}$ says:

Proponents of OC *-r- think, for example, that *-r- is a useful way to explain the absence of dental series onsets in Div. II because perhaps OC dental onsets like *t- + medial *-r- $>>$ not Middle Chinese dental [ $\left.{ }^{\stackrel{\imath}{ }}\right]$ t- 
but rather retroflex stops "[ $\left.{ }^{\circledR}\right]$ tr-" or some similar ( $>$ affricates $\approx / \mathrm{ts} /$ in many modern varieties.) That is, this group of authors emphasizes concrete phonetic values and plausible diachronic changes, and points out that similar changes to $\mathrm{Cr}$ - clusters have occurred in other languages.

\section{Referee D says:}

Yakhontov thought MC [ $\left.{ }^{\star}\right] 1-$ reflected OC [*]1-, but if one admits that $\mathrm{MC}$ [ $\left.{ }^{\star}\right] 1$ - goes back to a retroflex OC * $\mathrm{r}$-, then the distribution of ' + ' and '-' in the table is clarified: the division 1 line represents OC initials without medial [*]-r- and division 2 the same initials with medial [*]-r-. MC retroflexes come from apicals plus [*]-r-, which is phonetically highly plausible. The author(s) do not mention retroflexes once in their paper.

This issue is actually not relevant to the present study, but we answer it. First, the sound change $/ \mathrm{rt} />/ \mathrm{t} /$ is attested in Swedish, not $/ \mathrm{tr} />/ \mathrm{t} /$, cf. $\boldsymbol{k a r t a}\left[{ }^{2} \mathrm{k}^{\mathrm{h}} \mathrm{a}: \mathrm{ta}\right]_{\text {'map }}$, but

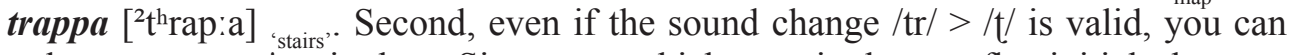
only reconstruct *-r- in those Sinograms which contain the retroflex initials, but you have reconstructed *-r- in all the division-2 Sinograms, at least. There is no evidence for your practice.

\subsection{Sino-Vietnamese evidence for the vocalic medial for division-2 in $O C$}

What are more plausible values for the divisions in OC? They are vocalic medials. Wáng L. (1957, 1980a, 1985) listed the vocalic medial *null/-u- for division-1, *-e-/-o- for division-2, *-i-/-iu- for division-3, *-i-/-iu- for division-4. When you do not find these vocalic medials in Tibeto-Burman languages, you cannot change the plausible vocalic values of OC to your liquid values according to Tibeto-Burman languages, because they are different languages (even if you believe that they are genetically related); you have to reevaluate your Sino-Tibetan comparisons.

Here Referee $\mathrm{C}$ has completely misunderstood our point:

Most problematic is the discussion of comparative evidence. When arguing against $\mathrm{OC} *$-r-, the author considers irregular correspondences with TB -r-, etc., to be a serious defect. However, when arguing in favor of Wang Li's OC *-e-/-o-, the author considers irregular correspondences to be irrelevant (" $[\mathrm{w}]$ hen you do not find these vocalic medials in Tibeto-Burman languages $[\ldots]$ you have to reevaluate your Sino-Tibetan comparisons.")

This misunderstanding originates in their belief of "the Sino-Tibetan language family". In fact, we mean you have to reevaluate whether your Sino-Tibetan comparisons are valid or invalid. We do not imply that we accept your Sino-Tibetan comparisons. We do not imply that we leave the nonexistence of the vocalic medials in Tibeto-Burman languages as irregular correspondences in your "Sino-Tibetan language family". This serious defect is limited to the Sino-Tibetan comparisons. It is irrelevant to the etymological comparisons in other directions.

Wáng L. (1957, 1980a, 1985) reconstructed the vocalic medial *-e-/-o- for division-2 without demonstrating evidence. Wáng L. (1964: 44) compared it typologically to Old English medial $-e$ - and Vietnamese medial -o-. It is orally told 
that he had evidence for it from Archaic Sino-Vietnamese. We have researched Wáng's original paper on Sino-Vietnamese (Wáng L. 1948) and made a division correspondence table (Table 5) with his etymological comparisons to division-2.

Based on the comparative evidence in Table 5, Sinitic division-2 is correlated to the vocalic medial $-\boldsymbol{e}-/-\boldsymbol{o}$ - in Archaic Sino-Vietnamese. Wáng L. (1948: 5863) introduced the differences between Archaic Sino-Vietnamese古漢越語 and undifferentiated Sino-Vietnamese 漢越語 and implied that the distinction between division-1 and division-2 is lost in undifferentiated Sino-Vietnamese but not in Archaic Sino-Vietnamese ${ }^{12}$. Therefore, his argument cannot be opposed with counterexamples in undifferentiated Sino-Vietnamese. Without considering this

Table 5. Division correspondence (Dc2021GaoJ-1406-0922-T5-1948WangL-1562-5915):

Sinitic division-2 $\Leftrightarrow$ OC-W* -e-/-o- $\Leftrightarrow$ Archaic Sino-Vietnamese -E-/-o- (-e-/-o-)

(DOM and non-orthographical Vietnamese data from Wáng L. 1948: 60-65)

\begin{tabular}{|c|c|c|c|c|c|}
\hline DOM & $1161-Y J$ & OC-W & OC-Z & Archaic Sino-Vietnam ese & Sino-Vietnamese \\
\hline \multirow{2}{*}{ 【巧】 } & division-2 & $* \mathrm{k}^{\mathrm{h}} \mathrm{eu}$ & $* \mathrm{k}^{\mathrm{h}} \mathrm{ru}:$ ? & kheo $^{5}$ (khéo) & xao $(\boldsymbol{x} a ̉ o)$ \\
\hline & \multicolumn{3}{|c|}{ 121-SW:技也('skill') } & 检冺、鳤敏('('quick-witted') & \\
\hline \multirow{2}{*}{ 【誇】 } & division-2 & ${ }^{*} \mathrm{k}^{\mathrm{h}} \mathrm{Oa}$ & $* \mathrm{k}^{\mathrm{hw}} \mathrm{ra}$ & $\operatorname{khoE}^{1}(\boldsymbol{k} \boldsymbol{h o a})$ & khoe $^{1}(=$ khoa $)$ \\
\hline & \multicolumn{3}{|c|}{ 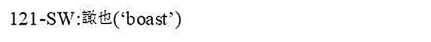 } & -- & \\
\hline \multirow{2}{*}{ 【膠】 } & division-2 & *keu & *krur:w & $\mathrm{kEO}^{1}(\boldsymbol{k e o})$ & giao $^{1}$ (giao) \\
\hline & \multicolumn{3}{|c|}{ 121-SW:曜也('close') } & 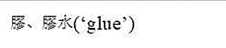 & \\
\hline \multirow{2}{*}{ 【櫂】 } & division-2 & *deôk & *r'e:wGS & $\operatorname{chEo}^{2}$ (chèo) & $\operatorname{trao}^{5}(\operatorname{trago})$ \\
\hline & \multicolumn{3}{|c|}{ 121-SW:所以迤输也他('oar') } & 通紫('soup') & \\
\hline \multirow{2}{*}{ 【貓】 } & division-2 & *meô & *mre:w & $\mathrm{MEO}^{2}$ (mèo) & $\operatorname{mieu}^{1}(\boldsymbol{m i e ̂ u})$ \\
\hline & \multicolumn{3}{|c|}{ 121-SW:经襗('cats') } & -- & \\
\hline \multirow{2}{*}{ 【卯】 } & division-2 & *meu & *mru:? & $\mathrm{mEO}^{6}(\boldsymbol{m e o})$ & $-(\boldsymbol{m \tilde { a } o})$ \\
\hline & \multicolumn{3}{|c|}{ 121-SW:需也('cap') } & -- & \\
\hline \multirow{2}{*}{ 【豹】 } & division-2 & *peôk & *pre:WGS & $\mathrm{bEO}^{1}($ beo $)$ & bao $^{5}$ (báo) \\
\hline & \multicolumn{3}{|c|}{ 121-SW:似虎園文('leopard') } & -- & \\
\hline \multirow{2}{*}{ 【槐】 } & division-2 & *yoəi & *gru:1 & $\operatorname{hoE}^{2}(\boldsymbol{h o} \grave{e})$ & $--(=h o \grave{e})$ \\
\hline & \multicolumn{3}{|c|}{ 121-SW:木地('tree [pagoda]') } & -- & \\
\hline
\end{tabular}

${ }^{12}$ Wáng L. (1948：63): “所謂外轉二等韻[…]依上文所述的漢越語的系統來看, 它們的韻值和 一等韻完全相同 [...]但是, 我們相信古漢越語裏的情形并不如此。” 'The so-called extrovert division-2 rhymes [...] in the Sino-Vietnamese system, discussed in the foregoing paragraphs, are phonologically identical to division-1 rhymes [...] But we believe that it was not so in Archaic SinoVietnamese.' 
caveat, Referee D lists undifferentiated Sino-Vietnamese counterexamples. If you really want to testify against this division correspondence, you should do a negative control with division-3 counterexamples in Archaic Sino-Vietnamese.

Referee A questions: "What is your counterargument against the SinoVietnamese borrowings postdating the shift of $*^{*}{ }>*_{\varepsilon}$ (according to descriptivisttype reconstructions)?" This postulation is invalid. Despite the flaw of external comparative evidence for ${ }^{*}$-r- as we have discussed in previous paragraphs, there is no internal comparative evidence for *-r-. One of these division-2 etyma, the etymon【貓】 'cat', is obviously of an onomatopoetic origin from the vocalization of cats, cf. English meow; French miaou; German/Spanish/Portuguese/Polish/ Lithuanian/Finnish/Hungarian miau; Italian miao; Dutch miauw; Danish mjav;

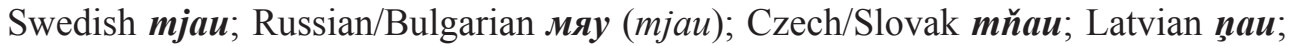
Estonian mäu/näu; Turkish miyav; Korean 야옹(yaong)/냥(nyang); Japanese にや - (nyā); Indonesian meong; Arabic sُ (muwaa'). Onomatopoetic words are very conservative. This etymon must be already * [mraw] (cf. OC-W*meô) when it was formed in OC. The descriptivists' side's reconstruction with *-r- such as *mre:w is apparently invalid, because cats are not able to pronounce [r]. Referee B claims: "Note that cats meow differently in different languages. Old Chinese and modern Sinitic languages are different languages, we never know how Old Chinese speakers interpreted cat sounds." We must reply: Do not argue without evidence. Can you give any example that the vocalization of cat is interpreted with a liquid medial in any human language? OC speakers must be of the same human being. Referee D says: "Actually it is not uncommon in English to interpret cat vocalization as mra(a)w. Examples gathered from the internet. [...]" We thank Referee D for gathering it from the internet. However, this fact reveals that this personal $-r$ - is rather secondary to $-\boldsymbol{e}$ in English. First, English -r - being postalveolar approximant [I] differs distinctly from Swedish -r-being alveolar trill [r] which can make the retroflex consonants. Second, by seeing the English equivalents meow, mraw and mraaw, shall we reconstruct any Proto-English *mreow? We cannot reconstruct it because it is against the English philology and the nature of the vocalization of cats. If you agree with it, why would you insist on reconstructing the form *mre:w for cats in OC?

Referee $\mathrm{C}$ does not insist on *mre:w for cats in OC but argues:

The author discusses sound symbolic words like māo 貓 'cat'. Here they could consult for instance Axel Schuessler, "What are cognates and what are variants in Chinese word families" (Papers from the Third International Conference on Sinology, Linguistics Section, 2003: 231): “[...] not all div. II syllables derive from OC r-clusters. [In some cases] a div. II vowel was preserved for reasons of sound symbolism. Generally, onomatopoetic words do not always follow regular phonological developments."

This argument is illogic. Once you accept that the onomatopoetic words do not always follow regular phonological developments, you have to accept that the vocalic value in the onomatopoetic words is more original. However, your implied phonological development is $*_{-r-}>*_{-e-}$, not $*_{-}$- $>*_{-r-}$. 
Referee A questions: "How do you explain 立 as a phonetic component in 泣 if the latter has no liquid?" We answer it. A velar stop may become a liquid via a uvular fricative: [g] > [ $\mathrm{b}]>$ [R], cf. German Kugel [' $\mathrm{k}^{\mathrm{h}} \mathrm{u}$ :gəl] 'ball $^{\text {> }}>$ Luxembourgish Kugel ['kh:вәl] 'ball $>$ Luxembourgish repeated by Dutch ['ku:Rəl]. There could be some OC dialect with similar sound changes. This dialect formed those Sinograms in which velar stops and liquids are correlated.

Referee D says:

This is very hard to believe. First, the explanation does not work for alternations between labials and [ $\left.{ }^{[\star}\right] 1-$, as in 凌 vs 冰; second, if 立 had a velar initial in OC without medial [*]-r-, then one would expect to see a velar without -r- in TB languages; but the TB word for 'weep' has a Kr- type cluster in many branches: Tani, Deng, Kuki-Chin, Naga, Garo, northern Naga, Jingpo, Kanauri, Tibetan, Burmese... see https://stedt. berkeley.edu/ stedt-cgi/rootcanal.pl/etymon/1103.

For the first part, a labial stop may become a labial trill and then an alveolar trill: [b] $>$ [в] $>[\mathrm{r}]$. For the second part, it is again about the validity of Sino-Tibetan comparisons. You have not confirmed this Sino-Tibetan comparison with a regular sound correspondence consisting of multiple etyma. An etymological comparison cannot be confirmed without a regular sound correspondence, no matter how similar the compared words are. A regular sound correspondence cannot be established with only one etymon, no matter how many equivalents or branches of that one etymon you demonstrate. Moreover, the etymon【泣】 is not of division-2 but of division-3. Even if it is a valid comparison, it does not support the basis of the liquid medial hypothesis.

We deny the liquid medial. We do not deny the possible existence of some additional liquid element, i.e. the liquid affix. This liquid affix is not relevant to any division but to the rhotacization or erhua 兒化 in Sinitic. Valid Sino-X comparisons involving non-Sinitic -r-/-1- should be explained in this direction. Nobody would try to explain the Sinitic rhotacization with the Sinitic divisions.

We should clarify that the descriptivists' side is not a single academic camp that must protect the liquid medial hypothesis as its basis. A few descriptivists, Pulleyblank (1965: 206), Jacques (2015) and Hill (2019: 196), have already questioned whether all division-2 come from *-r-. They have recognized similar logical problems of the liquid medial hypothesis. They just have not gone so fast to reject the whole hypothesis as the Sino-linguists do from the beginning.

We end this section with Jacques' words (Jacques 2015: 220):

Third, an alternative possibility is that the present models of Old Chinese reconstruction (including Starostin 1989, Schuessler 2009, and Baxter and Sagart 2014) overestimate the quantity of syllables with medial or prefixed $*_{r}$ - in Old Chinese by overgeneralization. [...] there is no definite proof that ${ }^{*}$-r- should be reconstructed in all cases. 


\subsection{Sino-Uralic evidence for the vocalic medial for division-2 in OC}

Now that we have disabused ourselves of the assumption that division-2 word roots reconstruct to *-r-, a number of Sino-Uralic comparisons appear strengthened by assumption that *-r- is not at play.

Sinitic division- 2 is correlated to the vocalic medial (called $V_{1}$ in Uralic linguistics) $-\tilde{\boldsymbol{\sigma}}$ - $[\gamma]$ ] $]$ or $\boldsymbol{- o}-[0]$ in Estonian and Finnish. This is a division correspondence consisting of six (6) etyma (see Table 6).

Table 6. Division correspondence (Dc2021GaoJ-1406-0922-T6):

Sinitic divisiton-2 ('d2' in this table) $\Leftrightarrow$ OC-W ${ }^{*}-e-/-o-\Leftrightarrow$ Estonian $-\tilde{o}-/-o-\Leftrightarrow$

Finnish/ North Sami -o- (demonstrated etyma from Section 4)

\begin{tabular}{|c|c|c|c|c|c|c|c|c|c|}
\hline DOM & \multicolumn{2}{|c|}{$1161-Y J$} & OC-W & OC-Z & Estonian & Finnish & North Sami & Erzya & Hungarian \\
\hline \multirow{2}{*}{ 【家】 } & ${ }^{k o ́}{ }^{A}$ & $\mathrm{~d} 2$ & *kea & *kra: & $k o d a \backslash k o j a$ & kota & goahti & kudo & ház \\
\hline & \multicolumn{4}{|c|}{ 121-SW:屏也('dwelling') } & 'chamber' & 'Sami dwelling' & 'Sami diwelling' & "house & 'house, home' \\
\hline \multirow{2}{*}{ 【界】 } & kóaj $^{\mathrm{C}}$ & $\mathrm{d} 2$ & *keat & *kre:ds & koht koha & kohta & -- & - & -- \\
\hline & \multicolumn{4}{|c|}{ 121-SW:摬也('boundary') } & 'place' & 'place' & & & \\
\hline \multirow{2}{*}{ 【殺】 } & ${ }^{*} \theta$ óat $_{n}^{\mathrm{D}}$ & $\mathrm{d} 2$ & * Jeat & *sre:d & $s \tilde{\tilde{o}} d a \backslash s \tilde{o} j a$ & sota & soahti & śudo- & (?) Szid- \\
\hline & \multicolumn{4}{|c|}{ 121-SW:䇣也('kill') } & 'war' & 'war' & 'war' & 'curse' & 'chide' \\
\hline \multirow{2}{*}{ 【桠】 } & Póa & $\mathrm{d} 2$ & *ea & *qra: & oda & ota & oahci & $O \check{S}$ & -- \\
\hline & \multicolumn{4}{|c|}{ 543-YP:木不梪极('(tree fork') } & 'spear' & 'sting' & 'obstacle' & 'town' & \\
\hline \multirow{2}{*}{ 【江】 } & ${ }^{7}$ koan $^{A}$ & d2 & *keon & *kro:1] & jõgi jõ̃e & jokiljoe- & johka & Jov & $-j o ́$ \\
\hline & \multicolumn{4}{|c|}{ 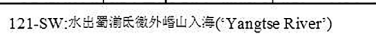 } & 'river' & 'river' & 'river' & 'Moksha River' & '†-river' \\
\hline
\end{tabular}

Since this correspondence is of a high coincidental probability, one out of four $(1 / 4)$ possible values $(\mathrm{d} 1, \mathrm{~d} 2, \mathrm{~d} 3, \mathrm{~d} 4)$, a negative control is required and given in Table 7. In this negative control, ten non-division-2 etyma are observed, that they should not yield the hypothesized phonetic outcome, e.g. $-\tilde{\boldsymbol{o}}-/-\boldsymbol{o}-$ in Estonian and Finnish.

As shown in this negative control, the division-1, division-3 and division-4 etyma do not yield the hypothesized phonetic outcome (line 7 row 9 North Sami outcome goaivu-alone with an unexpected -o- is apparently secondary). This negative control passed. The division correspondence Dc2021GaoJ-1406-0922-T6 is reliable.

Based on the comparative evidence above, Sinitic division-2 is correlated to

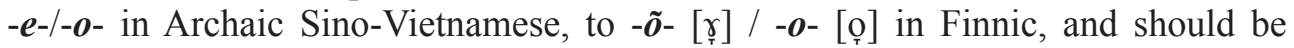
reconstructed as $*_{-0}-[\gamma]$ ] $] / *_{-0}-[\mathrm{o}]$ in OC. 
Table 7. Division correspondence negative control:

NEGATIVE \{Sinitic division-2 $\Leftrightarrow$ OC-W *-e-/-o- $\Leftrightarrow$ Estonian $-\tilde{\tilde{o}}-/-o-\Leftrightarrow$

Finnish/ North Sami -o-\} (demonstrated etyma line 1-4 from Section 4, reinforced etyma line 5-10 from Gao 2019a and Gao 2020b)

\begin{tabular}{|c|c|c|c|c|c|c|c|c|c|}
\hline DOM & \multicolumn{2}{|c|}{$1161-\mathrm{YJ}$} & $\mathrm{OC}-\mathrm{W}$ & $\mathrm{OC}-\mathrm{Z}$ & Estonian & Finnish & North Sami & Erzya & Hungarian \\
\hline \multirow{2}{*}{ 【峰】 } & $\mathrm{p}^{\mathrm{h}} œ \mathrm{n}^{\mathrm{A}}$ & d3 & * $\mathrm{p}^{\mathrm{hi}}$ ion & *p $\mathrm{p}^{\mathrm{h}} \mathrm{OI}$ & mägìmäe & mäkilmäe- & -- & -- & -- \\
\hline & \multicolumn{4}{|c|}{ 121-SW:山弃也('mountain top') } & 'mountain' & 'hill' & & & \\
\hline \multirow{2}{*}{ 【丰】 } & $\left.\mathrm{p}^{\mathrm{h}} \mathrm{e}\right]^{\mathrm{A}}$ & d3 & * $\mathrm{p}^{\mathrm{h} \text { ion }}$ & ${ }^{*} \mathrm{p}^{\mathrm{h}}$ on & vägilväe & väki|väe- & viehka & $v i j$ & -- \\
\hline & \multicolumn{4}{|c|}{ 121-SW:粆昰生生地('abundant') } & 'force' & 'crowd' & 'rather' & 'force' & \\
\hline \multirow{2}{*}{ 【曈】 } & 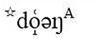 & d1 & $*$ doy & $*$ do:y & näge-\näe- & näke-\näe- & niehku & ńeje- & $n e ́ z-$ \\
\hline & \multicolumn{4}{|c|}{ 543-YP:目治子('eye ball') } & 'see' & 'see' & 'dream' & 'see' & 'look' \\
\hline \multirow{2}{*}{ 【動】 } & * dó̀əy ${ }^{\mathrm{B}}$ & $\mathrm{d} l$ & $*$ doy & *do:y? & tege-ltee- & teke-ltee- & dahka- & teje- & tesz- \\
\hline & \multicolumn{4}{|c|}{ 121-SW:作也('do') } & 'do, make' & 'do, make' & 'do, make' & 'do, make' & 'do, make' \\
\hline \multirow{2}{*}{ 【書】 } & ${ }^{*}$ teəw ${ }^{c}$ & d3 & *tin & $*$ tus & taevas\taeva & taivas \taivaa- & -- & -- & -- \\
\hline & \multicolumn{4}{|c|}{ 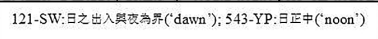 } & 'sky' & 'sky' & & & \\
\hline \multirow{2}{*}{ 【求】 } & ${ }^{2 \pi}$ geəw $^{A}$ & d3 & *giu & *gu & $\underline{\text { kaevata } \backslash k a e b a-}$ & kaivata $\backslash$ kaipaa- & gáibidi- & -- & -- \\
\hline & \multicolumn{4}{|c|}{ 121-SW:索也('demand') } & 'accuse' & 'yearn for' & 'demand" & & \\
\hline \multirow{2}{*}{ 【究】 } & keəw ${ }^{c}$ & d3 & *kinu & *kus & kaevata\kaeva- & kaiva- & goaivu- & -- & -- \\
\hline & \multicolumn{4}{|c|}{ 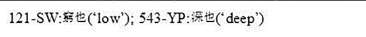 } & 'dig' & 'dig' & 'dig' & & \\
\hline \multirow{2}{*}{ 【流】 } & ${ }_{n}^{\prime} \operatorname{le}^{\mathrm{A}}$ & d3 & $* \operatorname{lin}$ & $*_{\mathrm{ru}}$ & laev\laeva & laiva & láivi & -- & -- \\
\hline & \multicolumn{4}{|c|}{ 121-SW:水行也('flow') } & 'ship' & 'ship' & 'vessel, ship' & & \\
\hline \multirow{2}{*}{ 【太】 } & "dọañ ${ }_{n}^{\mathrm{C}}$ & d1 & $*$ that & $*$ tha:ds & täht tähe & tähtìtähte- & -- & -- & -- \\
\hline & \multicolumn{4}{|c|}{ 543-YP:甚也(extremely') } & 'star, sign' & 'star, sign' & & & \\
\hline \multirow{2}{*}{ 【列】 } & ${ }^{\prime} \operatorname{leat}_{n}^{\mathrm{D}}$ & $\mathrm{d} 4$ & *liat & $*_{\text {red }}$ & lahtlahe & lahtivahte- & luokta & -- & -- \\
\hline & \multicolumn{4}{|c|}{ 121-SW:彷鲜也(divide) } & 'bay' & 'bay, open' & 'bay' & & \\
\hline
\end{tabular}

\section{Results}

\subsection{Etymological results}

Full etymological results of the etyma demonstrated in Table 8 and Table 9 are presented here.

\#1)【家】【說文(121-SW): 居也('dwelling'); 篇(543-YP): 居也家室也('dwelling, home'); 韻鏡(1161-YJ):外轉第二十九開 二等平聲牙音清(extrovert, final-29, labialized-, division-2, tone-A, velar initial voiced-) ( ${ }^{\natural 0} \mathrm{k}^{\mathrm{A}}$ ); Mandarin jiāa 'home, family; Cantonese gaal/gul 'home, family; Minnan ka/ke ‘dwelling, home; Japanese Go-on ke/ku; Kanon ka/ko; \{OC rhyme 魚 *-a; OC-W *kea; OC-Z “*kra:”\} $]$ has been compared ( $\triangle$ Gāo J. 2008: 168) to the Uralic etymon after the equivalents: Estonian koda $\backslash$

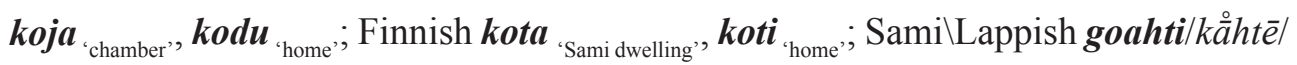

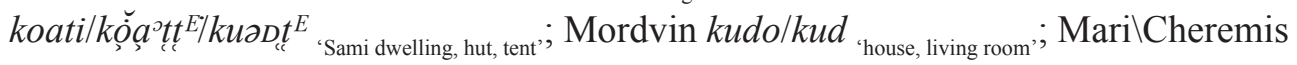




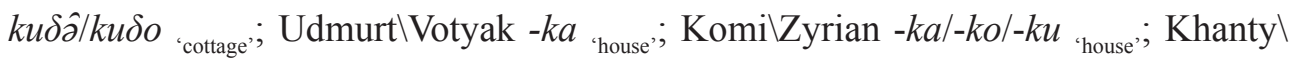

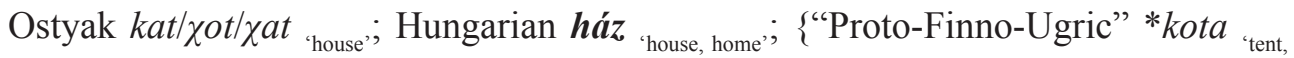
hut, house' $(1988-U E W: 190)\} ;\left\{\right.$ Uralic $\Leftarrow$ Shennong $^{13}$ (Sino-Uralic) *kóta ${ }_{\text {dwelling' }} \Rightarrow$ Sinitic $\}$. This etymon has not been identified in other languages. ${ }^{14}$

\#2)【街】(split匹介，界］）【說文(121-SW): 四通道也('street') ～[介]畫也('draw')，[畍]境也('boundary'); 玉篇(543-YP):

四通道也('street') ～[介]甲也大也助也紹也說文畫也('turtle shell, big, help, introduce; draw(121-SW)'), [界(畍)]疆界 垂也('boundary'); 韻鏡(1161-YJ): [佳]外轉第十五開二等平聲牙音清(extrovert, final-15, labialized-, division-2, tone-A, velar initial voiced-) $\left({ }^{\text {㸚 }} \mathrm{K}^{c} \mathrm{aJ}^{\mathrm{A}}\right) \sim$ [誡]外轉第十三開二等去聲牙音清(extrovert, final-13, labialized-, division-2, tone-C, velar initial voiced-)

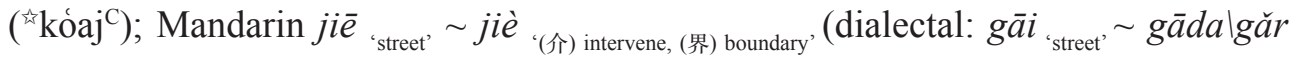
'place'); Cantonese gaail gaai3 '(介) intervene, (界) boundary; , Minnan ke/kue 'street' $\sim$ kài/kèl kuè “(介) intervene, (界) boundary; Japanese Go-on ke; Kan-on kai; \{OC rhyme 支*-ja; OC-W *ke; OC-Z “*kre:” OC rhyme 月 *-ta; OC-W *keat; OC-Z “*kre:ds”\}】 has been compared ( $\triangle$ Gāo J. 2008: 160) to the Uralic etymon after Estonian koht $\backslash k o h a a_{\text {"place", }}$ $\boldsymbol{k o h t a}_{\text {'about; }}$ Finnish kohta ${ }_{\text {'place; }}$; Selkup kuupt/kuopta/kōptij/kōpt 'seatplace; \{ProtoUralic "*kopta" "place, (1988-UEW: 183)\}; $\{$ Uralic $\Leftarrow$ Shennong (Sino-Uralic) *kóta 'place, $\Rightarrow$ Sinitic\}.

This etymon has been identified ( $\triangle$ Gāo J. 2008: 160) in Germanic languages: Danish gade 'street" (gat 'hole, gat' $\leftarrow$ Low German $)$; Swedish gata ' 'street", (gatt/gat 'hole, gat' $\leftarrow$ Low German ); Norwegian gate 'street' (gat 'hole, gat' $\leftarrow$ Low German); Icelandic gata 'street, road', (gat "hole' $\leftarrow$ Low German); Old Norse gata "path, way, road', (gat "hole, gat' $\leftarrow$ Low German); English gate; Old

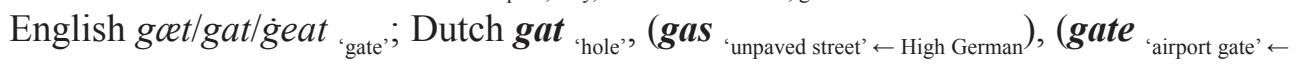
English); Old Low German gat 'hole, German Gasse 'lane', (Gatt 'hole for rope or hook' $\leftarrow$ Low German $)$, $\left(\right.$ Gate $\left._{\text {'airport gate' } \leftarrow \text { English }}\right)$; Old High German gazza 'ane; Gothic gatwō 'street' $(\rightarrow$ Finnish

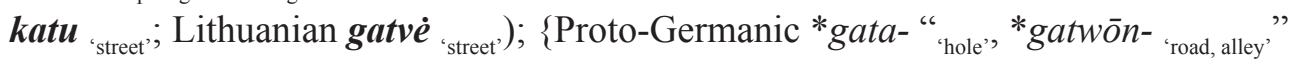
(2013-EDPG: 170) $\left.{ }^{15}\right\} ;\{\leftarrow$ or $\Leftarrow$ Shennong (Sino-Uralic) $\}$.

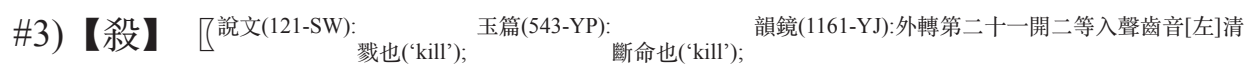
(extrovert, final-21, labialized-, division-2, tone-D, dental initial [fricative+] voiced-) $\left({ }^{\star} \theta\right.$ óat $\left.{ }_{n}^{\mathrm{D}}\right)$; Mandarin $\operatorname{sh} \bar{a}(\hat{s} \bar{a})$ "kill';

${ }^{13}$ Gāo J. (2008: 109-114; Gao 2012: 241; Gao 2019c: 145-146) put forward that the Shennong nation 神農氏 (a.k.a. Yandi clans 炎帝部落, of Chinese prehistory) is the shared origin of Sinitic and Uralic languages and peoples.

${ }^{14}$ Refutation: Previously claimed (1977-FUV: 142) etymological equation from Uralic to Persian kad 'house' is rejected due to phonetic inconsistencies (no rhyme correspondece). Previously claimed (1996-CV5ST) etymological equation from Sinitic to Burmese kra?-hyanh 'palace, residence' is rejected due to phonetic inconsistencies. Previously claimed (2007-EDOC: 300) etymological equation from Sinitic to Tibetan $m k^{h} a r$ 'house, castle' is rejected due to phonetic inconsistencies.

${ }^{15}$ Refutation: Previously claimed (2013-EDPG: 170, 176) etymological equation from ProtoGermanic to Proto-Indo-European * $g^{h} e ́ d-e-;$ Greek $\chi \alpha v \delta \alpha ́ v \omega$ (khandánō) 'to hold, include, contain'; etc. is rejected due to semantic inconsistencies. 
Cantonese saat3/saai3 'kill; Minnan sat "kill; Japanese Go-on sei/sechi/setsu; Kan-on sai/satsu; \{OC rhyme 月*-ta; OC-W * feat; OC-Z “*sre:d"\}】 has been compared

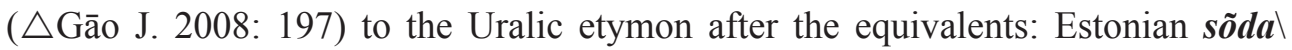

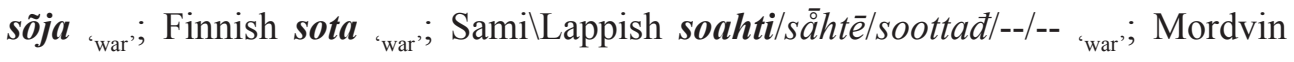

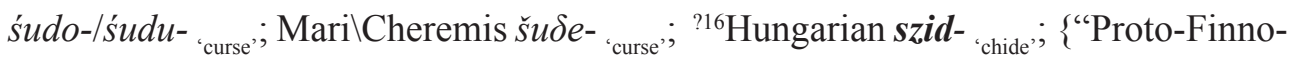

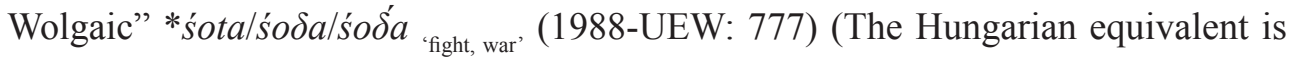
retrieved in the present study) $\} ;\left\{\right.$ Uralic $\Leftarrow$ Shennong (Sino-Uralic) $* \theta$ ótra $_{\square \text { kill }} \Rightarrow$ Sinitic $\}$.

This etymon has been identified (2007-EDOC: 452) in surrounding languages: Tibetan gsod-pa, bsad 'kill'; Nung sat 'kill; Chepang $\underline{s a t-s a}$ "kill; Burmese sat "kill; Jingpho\Kachin sat ${ }^{3 l}$ "kill'; Mizo\Lushai that "kill'; KarbilMikir that "kill; Dimasa thai 'kill; ;aro sot ${ }_{\text {'kill }}$; $\{$ Proto-Tibeto-Burman *g-sat (Benedict 1972: 27)\}; \{Proto-Monic *k-r-cot $\left.{ }_{\text {kill }}\right\} ;\left\{\leftarrow\right.$ Sinitic $\left._{{ }_{\text {kill }}}\right\}{ }^{17}$.

\#4)【椏】【說文(121-SW): 王篇(543-YP):

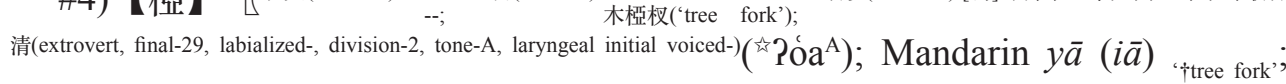
Cantonese aal/ngaal "trree fork'; Minnan a/ue “trree fork; Japanese Go-on $e$; Kan-on $a$; \{OC rhyme 魚*-a; OC-W *ea; OC-Z “*qra:”\}】 is compared (first publication) to the Uralic etymon after Estonian oda ${ }_{\text {spear }}$; Finnish ota ${ }_{\text {sting'; }}$ SamilLappish oahci/

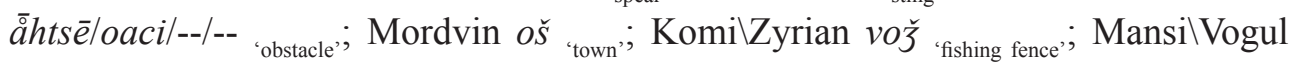
$\bar{o} \check{s} / \bar{u} s / w \bar{u} \check{s} / \bar{u} \check{s}$ 'fence, town; KhantylOstyak wač/woš/was "town; Nenets $\backslash$ Yurak wā? 'fence;

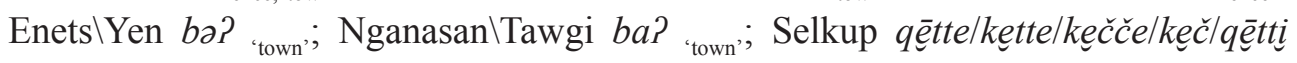
"town; \{Proto-Uralic “*woča "fence, fishing fence; catch fish with a trap" (1988-UEW: 577)\}; \{Uralic $\Leftarrow$ Shennong (Sino-Uralic) * Potta 'tree fork using for fence' $\Rightarrow$ Sinitic\}. This etymon has not been identified in other languages.

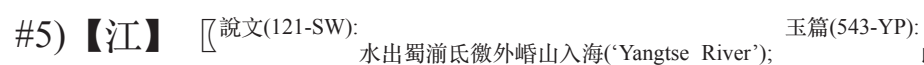

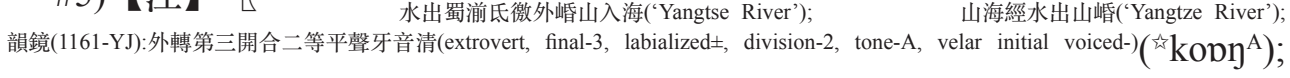
Mandarin jiāng (jiāy) "siver (of South and Northeast China), Cantonese gong2 'river (of South and Northeast

${ }^{16}$ CAVEAT: Uncertain equivalent due to irregular outcome in the rhyme correspondence Rc2021GaoJ1406-0922-T8, see Table 8.

${ }^{17}$ Because there is almost no internal diversity in Tibeto-Burman and the sense in Tibeto-Burman is identical to Sinitic, it must be a non-genetic diffusion (loanword) from Sinitic. The $g$ - part in Tibetan gsod-pa belongs to another morpheme. The word gsod-pa should be a dimorphemic hybrid doubling compound containing of a native term * $g V C$ for 'kill' and the diffused term -sod 'kill'. Dimorphemic hybrid doubling compounds are common in Sinitic, e.g. in Mandarin, in the word 殺 翏 $s h \bar{a}$-lù 'killing', the second morpheme 戮 lù 'to kill (literary only)' is a non-genetically diffused term; in the word 屠殺 tú-sha 'slaughtering', the first morpheme 屠 tú 'to slaughter (literary only)' is a non-genetically diffused term. Native Mandarin speakers without education may only guess the meanings of these two compound words with the native term 殺 sha 'to kill' in them. 
China); Minnan kang "river (of South and Northeast China); Japanese Go-on $k \bar{o}$; Kan-on $k \bar{o}$; $\{\mathrm{OC}$ rhyme 東*-no; OC-W *keon; OC-Z “*kro:y”\} ] has been compared ( $\triangle$ Gāo J. 2008: $155)$ to the Uralic etymon after the equivalents: Estonian jõgiljõ e ${ }_{\text {river }}$; Finnish jokil

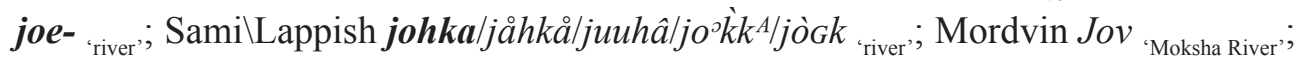
Mari\Cheremis joye- 'flow; Udmurt\Votyak ju-šur 'river; Komi\Zyrian ju 'river; Khanty\

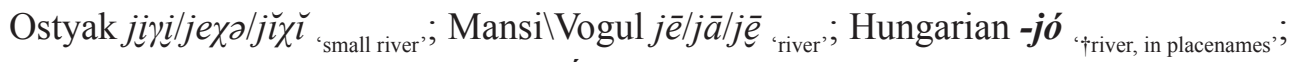

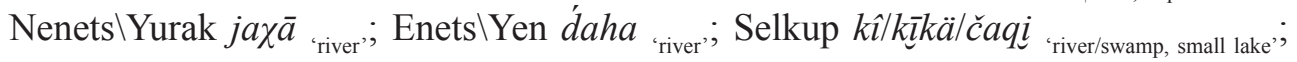
Kamass ćaya 'river'; \{Proto-Uralic *joke 'river' (1988-UEW: 99)\} \{Uralic $\Leftarrow$ Shennong (Sino-Uralic) $* \mathrm{k}^{\mathrm{j} o \eta} \mathrm{k}^{\mathrm{w}}{ }{ }_{\text {'river' }} \Rightarrow$ Sinitic $\}$. This etymon has not been identified in other languages. ${ }^{18}$

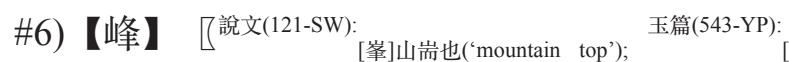

[峯]山耑也('mountain top'); [峯]高尖山('high and sharp mountain');

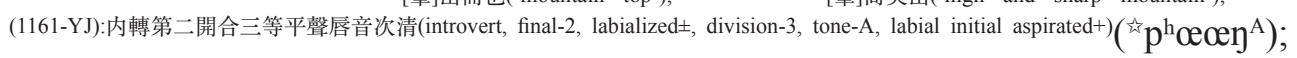
Mandarin fêng $(f \bar{e} y)$ "speak, Cantonese fungl 'peak; Minnan hong "peak; Japanese Go-

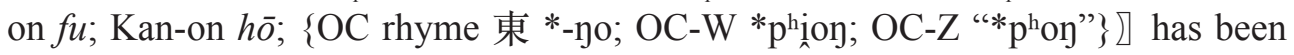
compared ( $\triangle$ Gāo J. 2008: 150) to the Uralic etymon after the equivalents: Estonian

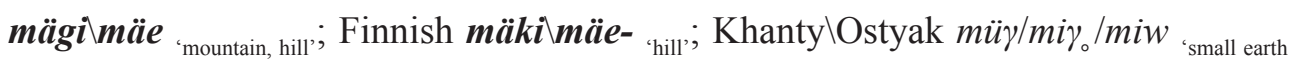
mound / earth cusp / lawn hill, Selkup maka/makka "lawn hill'; \{"Proto-Finno-Ugric" *mäke "hill, mountain (1988-UEW: 266) (The Selkup equivalents are retrieved in the present study)\} $\left\{\right.$ Uralic $\Leftarrow$ Shennong $\left(\right.$ Sino-Uralic) $*^{\text {mpœy } k^{w} ə \text { 'sharp mountain }} \Rightarrow$ Sinitic $\}$. This etymon has not been identified in other languages. ${ }^{19}$

＃7)【丰】(split【豐】）【說文(121-SW):

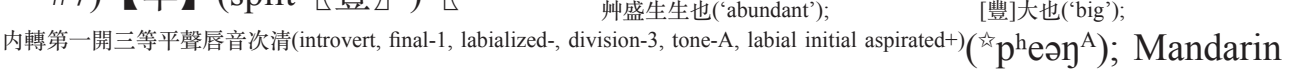
fèng (fēy) "abundant; Cantonese fungl 'abundant; Minnan hong 'abundant; Japanese Go-

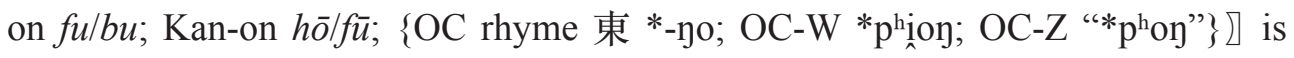
compared (first publication) to the Uralic etymon after the equivalents: Estonian vägi väe "force", väga "very'; Finnish väki väe- "crowd, †force; SamilLappish viehka/viehkal vieha/vie $k^{A} / \overline{v i}_{G}{ }_{\text {(rather/force, }}$ Mordvin vij/vi ${ }_{\text {force, }}$, Mari $\backslash$ Cheremis wi/wij 'force, Udmurt

${ }^{18}$ Refutation: Previously claimed (Yakhontov 1960: 7) etymological equation from Sinitic to Thai khlong 'canal' is rejected due to phonetic inconsistencies (no rhyme correspondence). Previously claimed (Norman and Mei 1976: 280; 2007-EDOC: 306) etymological equation from Sinitic to

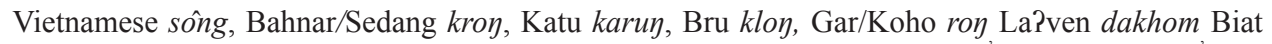
n'hoy, Hre khroay, Old Mon krung/kruy 'river'; \{Proto-Monic *krooy\}; Tibetan klun 'river'; Thai $k h l s: \eta$ 'canal'; Malay kron is rejected due to phonetic inconsistencies (no rhyme correspondence). Previously claimed (1996-CV5ST) etymological equation from Sinitic to Jingpho\Kachin kruךl 'valley'; Mizo \Lushai kuay 'the channel (of river)' is rejected due to phonetic inconsistencies (no rhyme correspondence).

${ }^{19}$ Refutation: Previously claimed (2007-EDOC: 238) etymological equation from Sinitic to Khmer $\mathrm{kpu \eta} \mathrm{'summit,} \mathrm{peak'} \mathrm{is} \mathrm{rejected} \mathrm{due} \mathrm{to} \mathrm{phonetic} \mathrm{inconsistencies.}$ 


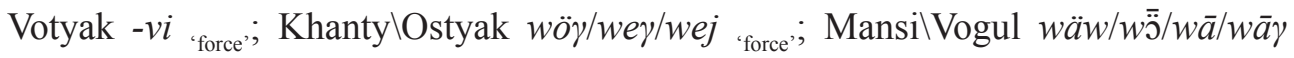
'force; Nenets \Yurak wika "force; \{Proto-Uralic *wäke "'force" (1988-UEW: 563)\} $\left\{\right.$ Uralic $\Leftarrow$ Shennong (Sino-Uralic) ${ }^{*}$ peyk ${ }^{w}{ }^{\text {' }}{ }_{\text {many }} \Rightarrow$ Sinitic $\}$. This etymon has not been identified in other languages. ${ }^{20}$

\#8)【瞳】【說文(121-SW): 玉篇(543-YP):

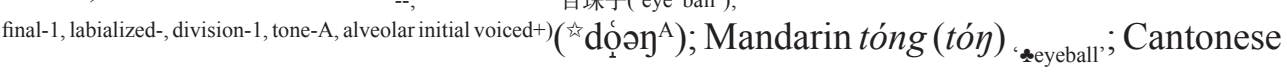
tung4 ‘eyeball; Minnan tông 'eyeball ; Japanese Go-on zü; Kan-on tō; \{OC rhyme 東 *-no; OC-W $*$ don; OC-Z $*$ do:y $\} \square$ is compared (first publication) to the Uralic etymon

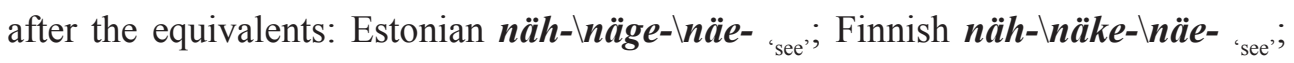
Sami \Lappish niehku/niehko/--/--/-- ‘dream (noun), niegadi-/niekati-/nievda-/niõgee-/ $n \bar{\gamma} \gamma_{\text {, ne- ‘dream (verb); }}$ Mordvin ńeje-/ńäjo- "see; UdmurtlVotyak naal- ‘look'; KhantylOstyak

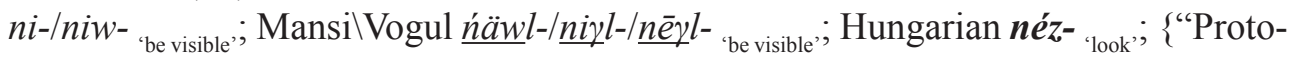
Finno-Ugric" *näke- 'see, look' (1988-UEW: 302)\}; \{Uralic $\Leftarrow$ Shennong (Sino-Uralic) *ntộnk ${ }^{w}{ }_{\text {eye ball }} \Rightarrow$ Sinitic $\}$. This etymon has not been identified in other languages.

\#9)【動】【說文(121-SW): 作也('do'); 王篇(543-YP): 振也作也('raise, do');

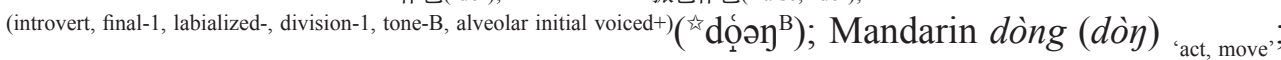

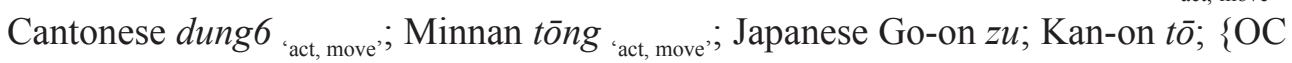
rhyme 東 *-no; OC-W *don; OC-Z *do:y?\}】 has been compared ( $\triangle$ Gāo J. 2008: 237) to the Uralic etymon after the equivalents: Estonian teh-|tege-|tee- 'do, make; Finnish teh-lteke-\tee- 'do, make; SamilLappish dahka-/tahka-/tooha-/tõõkkâ-/tegge'do, make; Mordvin teje-/tijo- 'do, make"; Hungarian tesz- ‘do, make; \{ "Proto-Finno-Ugric" *teke- ‘do, make (1988-UEW: 519)\}; \{Uralic $\Leftarrow$ Shennong (Sino-Uralic) *tộnkw ə-X ‘do, act $\Rightarrow$ Sinitic $\}$. This etymon has not been identified in other languages.

\subsection{Validation of the etymological results}

The etyma \#1-4 form a rhyme correspondence (see Table 8). A rhyme correspondence is a strict and composite rule of interdialectal sound correlations. A rhyme correspondence achieves that not only a single phoneme but also a composite rhyme (the $-\mathrm{VCv},-\mathrm{Cv}$ or $-\mathrm{v}$ part of a CVCv morpheme) is consistently correlated among related language varieties, thus ruling out chance resemblances. Different rhyme correspondences in Shennong (Sino-Uralic) etymologies have been published (Gao 2014, 2018, 2019a, 2019b, 2020a, 2020b; Gāo J. 2014; Gao and Tender 2020). We expect more Shennong (Sino-Uralic) rhyme correspondences in further studies.

${ }^{20}$ Refutation: Previously claimed (1988-UEW: 563) etymological equation from Uralic to Turkish bek 'firm, solid, stable'; Mongolian beki 'firm, solid, stable'; Manchu beki 'firm, solid, stable' is rejected due to phonetic and semantic inconsistencies. 
Table 8. Rhyme correspondence (Rc2021GaoJ-1406-0922-T8):

OC rhyme 魚*-a / 月 *-ta $\Leftrightarrow$ Mandarin $-a \Leftrightarrow$ Cantonese $-a a \Leftrightarrow$ Minnan $-a /-e \Leftrightarrow$ Estonian -oda

\begin{tabular}{|c|c|c|c|c|c|c|c|c|}
\hline DOM & Mandarin & Cantonese & Minnan & Estonian & Finnish & North Sami & Erzya & Hungarian \\
\hline 【家】 & $j i \bar{a}$ & gaal & ka/ke & koda $\backslash k o j a$ & kota & goahti & kudo & ház \\
\hline 魚*-a & 'home, family' & 'home, family' & 'dwelling' & 'chamber' & 'Sami dwelling' & 'Sami dwelling' & 'house & 'house, home' \\
\hline 【界】 & jiè & gaai3 & kài/kè/kuè & koht $\backslash k o h a$ & kohta & -- & -- & -- \\
\hline 月*-ta & 'boundary' & 'boundary' & 'boundary' & 'place' & 'place' & & & \\
\hline 【殺】 & $\hat{s} \bar{a}^{(s h \bar{a})}$ & sát/sái & sat & $s \tilde{o} d a \backslash s \tilde{o} j a$ & sota & soahti & śudo- & ${ }^{\text {(?) szid- }}$ \\
\hline 月*-ta & 'kill' & "kill" & 'kill' & 'war' & 'war' & 'war' & 'curse' & 'chide' \\
\hline 【椏】 & $i \bar{a}^{(y a \bar{a})}$ & aal & a/ue & oda & ota & oahci & oš & -- \\
\hline 魚*-a & 'tree fork' & 'tree fork' & 'tree fork' & 'spear' & 'sting' & 'obstacle' & 'town' & \\
\hline
\end{tabular}

$\Leftrightarrow$ Finnish - ota $\Leftrightarrow$ North Sami -oahti $\Leftrightarrow$ Erzya $-u d o$

The etyma \#5-9 form a rhyme correspondence (see Table 9).

Table 9. Rhyme correspondence (Rc2021GaoJ-1406-0922-T9):

OC rhyme 東 *-no $\Leftrightarrow$ Mandarin - $-\eta \Leftrightarrow$ Cantonese -ung $\Leftrightarrow$ Minnan -ong $\Leftrightarrow$ Estonian -Vgile $\Leftrightarrow$

\begin{tabular}{|c|c|c|c|c|c|c|c|c|}
\hline $\mathrm{DOM}$ & Mandarin & Cantonese & Minnan & Estonian & Finnish & North Sami & Erzya & Hungarian \\
\hline \multirow{2}{*}{$\begin{array}{c}\text { 【江】 } \\
\text { 束*-no }\end{array}$} & jiāāg ${ }^{\text {(jiâng) }}$ & gongl & kang & jōgiljõe & jokiljoe- & johka & Jov & $-j o ́$ \\
\hline & 'river' & 'river' & 'river' & 'river' & 'river' & 'river' & 'Moksha River' & '†-river' \\
\hline \multirow{2}{*}{$\begin{array}{l}\text { 【峰】 } \\
\text { 束*-no }\end{array}$} & $f \bar{e} \eta^{(f e n g)}$ & fung 1 & hong & mägilmäe & mäkilmäe- & -- & -- & -- \\
\hline & 'peak' & 'peak' & 'peak' & 'mountain' & 'hill' & & & \\
\hline \multirow{2}{*}{$\begin{array}{c}\text { 【丰】 } \\
\text { 束*-no }\end{array}$} & $f_{\bar{e}} \eta^{(f e ̂ n g)}$ & fung 1 & hong & vägìväe & väkiväe- & viehka & $v i j$ & -- \\
\hline & 'abundant' & 'abundant' & 'abundant' & 'force' & 'crowd' & 'rather' & 'force' & \\
\hline \multirow{2}{*}{$\begin{array}{c}\text { 【曈】 } \\
\text { 束*-no }\end{array}$} & tué (tóng) & tung4 & tông & näge-\näe- & näke-näe- & niehku & ńeje- & néz- \\
\hline & 'eye ball' & 'eye ball' & 'eye ball' & 'see' & 'see' & 'dream' & 'see' & 'look' \\
\hline \multirow{2}{*}{$\begin{array}{c}\text { 【動】 } \\
\text { 束*-no }\end{array}$} & duè̀ $\eta^{(d o ̀ n g)}$ & dung6 & tōng & tege-ltee- & teke-ltee- & dahka- & teje- & tesz- \\
\hline & 'act, move' & 'act, move' & 'act, move' & 'do, make' & 'do, make' & 'do, make' & 'do, make' & 'do, make' \\
\hline
\end{tabular}

Finnish -Vkile $\Leftrightarrow$ North Sami -Vhka $\Leftrightarrow$ Eryza -eje $\Leftrightarrow$ Hungarian -esz/-ez

This is a deep rhyme correspondence with five etyma. It is substantially evidential. Its coincidental probability ${ }^{21}$ is as low as $1 / 727,255,744$ : The first etymon with a rhyme $(29 / 29=1) *$ the first etymon has comparable onsets $(1 / 4$ [there are four sorts of onsets: labial, coronal, dorsal and laryngeal]) * the second etymon falls into the same OC rhyme group $(1 / 29$ [there are 29 rhyme groups in $\mathrm{OC}]) *$ the second etymon has

${ }^{21}$ It is comparable to a lottery probability for four (4) matching numbers chosen from 29 and five (5) matching numbers chosen from four (4) options, repeatedly. 
comparable onsets $(1 / 4) *$ the third etymon falls into the same OC rhyme group $(1 / 29)$ * the third etymon has comparable onsets $(1 / 4) *$ the fourth etymon falls into the same OC rhyme group $(1 / 29) *$ the fourth etymon has comparable onsets $(1 / 4) *$ the fifth etymon falls into the same OC rhyme group $(1 / 29) *$ the fifth etymon has comparable onsets $=1 * 1 / 4 * 1 / 29 * 1 / 4 * 1 / 29 * 1 / 4 * 1 / 29 * 1 / 4 * 1 / 29 * 1 / 4=1 / 724,255,744$.

Although the present paper has supported the Sino-linguists' side by refuting the liquid medial hypothesis of the descriptivists' side, we do not think that all the hypotheses of the descriptivists' side should be refuted. E.g. the tonogenesis hypothesis, *-x(-?)\-s for tone-B $\backslash \mathrm{C}$, has been supported with Sino-Uralic evidence (Gao 2014: 103-104). We will discuss the other hypotheses on future occasions.

\section{Conclusions}

The hypothesis of the liquid medial for division-2 in OC is refuted with philological arguments and a negative control of comparative evidence. The hypothesis of the vocalic medial for division-2 in OC is supported with Sino-Vietnamese and SinoUralic comparative evidence. Sinitic division-2 is correlated to - $\boldsymbol{e}-/-\boldsymbol{o}$ - in Archaic

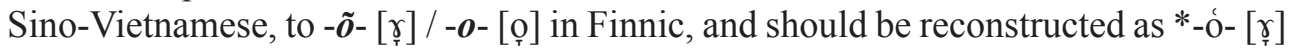
/*-o- $[\mathrm{o}]$ in OC.

Using etymological methods, the present study has identified nine (9) Sinitic and Uralic shared etymologies. Four (4) Shennong (Sino-Uralic) etymologies belong to a rhyme correspondence. Five (5) Shennong (Sino-Uralic) etymologies belong to another rhyme correspondence. These two (2) regular sound correspondences validate the etymological connections between Sinitic and Uralic.

\section{Acknowledgements}

A part of this study was first presented at the Chinese panel of The Second Baltic Alliance for Asian Studies Conference, Tartu, April 7-9, 2016. I would like to thank the participants for our useful discussions, especially Qiao Quansheng, Zhang Minquan, Sun Yuwen, Wang Weimin and Li Jianqiang. I would also like to thank Nathan W. Hill for his encouragements and comments on major versions of this paper.

This study is supported by the National Key R\&D Program of China (2020YFE0201600), the B\&R Joint Laboratory of Eurasian Anthropology (18490750300), the National Social Science Fund of China (20AZD126) and the Education Commission of Beijing (CIT\&TCD20190107).

Address:

Gao Jingyi 高晶一

School of European Studies

Beijing International Studies University

Dingfuzhuangnanli 1, Chaoyang, Beijing, China

E-mail: gao.jingyi@bisu.edu.cn 


\section{References}

121-SW = Xǔ, Shèn (121) Shuō wén jiě zì. Luò-yáng (Luoyang). Xú, Xuàn děng (jiào) (986). Dōng-jīng (Kaifeng).

543-YP = Gù, Yě-wáng (543) Yù piān. Jiàn-kāng (Nanjing). [Chén, Péng-nián děng (xiū)] (1013) Dà guăng yì huì yù piān. Dōng-jīng (Kaifeng).

1008-GY = [Chén, Péng-nián děng (xiū)] (1008) Dà sòng cóng xiū guăng yùn. Dōng-jīng (Kaifeng).

1161-YJ = Zhāng, Lín-zhī (xù) (1161) Yùn jìng. Lín-ān (Hangzhou).

1662-ELL $=$ [†Vossius, Gerardus Joannes] (1662). Gerardi Joannis Vossii Etymologicon linguae latinae. Amsterdam: Apud Ludovicum; Danielem Elzevirios.

1923-ADCSJ = Karlgren, Bernhard (1923) Analytic dictionary of Chinese and Sino-Japanese. Paris:

P. Geuthner.

1977-FUV = Collinder, Björn (1977) Fenno-Ugric vocabulary (second revised edition). Hamburg: Helmut Buske Verlag.

1987-DEZC = Schuessler, Axel (1987) A dictionary of Early Zhou Chinese. Honolulu: University of Hawai'i Press.

1988-UEW = Rédei, Károly (1988) Uralisches etymologisches Wörterbuch. Budapest: Akadémiai Kiadó. 1989-YSaS = Lehtiranta, Juhani (1989) Yhteissaamelainen sanasto. Helsinki: Suomalais-ugrilaisen Seura. 1989-SSS = Sammallahti, Pekka (1989) Sámi-suoma sátnegirji / Saamelais-suomalainen sanakirja.

Ohcejohka (Utsjoki): Jorgaleaddji.

1993-HZGJ = Lǐ, Zhēn-huá; Zhōu, Cháng-jí (biān-zhuàn) (1993) Hàn-zì gǔ-jīn zì-yīn biăo. Beijing: Zhonghua Book Company.

1996-CV5ST = Peiros, Ilia; Starostin, Sergei (1996) A comparative vocabulary of five Sino-Tibetan languages. Parkville: Department of Linguistics and Applied Linguistics, University of Melbourne. 2001-SSA = Itkonen, Erkki; Kulonen, Ulla-Maija (päätoimittajat) (2001) Suomen sanojen alkuperä: Etymologinen sanakirja (1/2/3) (2. painos). Helsinki: Suomalaisen Kirjallisuuden Seura; Kotimaisten Kielten Tutkimuskeskus.

2007-EDOC $=$ Schuessler, Axel (2007) ABC etymological dictionary of Old Chinese. Honolulu: University of Hawai'i Press.

2013-EDPG = Kroonen, Guus (2013) Etymological dictionary of Proto-Germanic. Leiden: Brill.

2014-HZZY = Lín, Lián-tōng; Zhèng-zhāng, Shàng-fāng (biān-zhuàn) (2014) Hàn-zì zì-yīn yăn-biàn dà-zì-diăn. Nanchang: Jiangxi Education Press.

[Anonymous] Jié yú jīn (2006) “Jiàn-shè chuàng-xīn-xíng yǔ-yán-xué”. Gǔ-Hàn-yǔ yán-jīū 2006, 1, 2-6.

Bái, Yī-píng [= Baxter, William H.]; Pān Wù-yún (2018) "Shàng-gǔ-yīn duì-tán shí-lù”. Yǔ-yán yán-jīu jí-kān $21(2018,2), 394-416$.

Baxter, William H. (1977) Old Chinese origins of the Middle Chinese chóngniǔ doublets: a study using multiple character readings. Doctoral dissertation. Ithaca: Cornell University.

Baxter, William H. (1992) A handbook of Old Chinese phonology. Berlin: Mouton de Gruyter.

Baxter, William H.; Sagart, Laurent (2014) Old Chinese: a new reconstruction. New York: Oxford University Press.

Beckwith, Christopher I. (2002) “The Sino-Tibetan problem”. In Medieval Tibeto-Burman languages, 113-158. Leiden: Brill.

Beckwith, Christopher I. (2006) "Old Tibetan and the dialects and periodization of Old Chinese". In Medieval Tibeto-Burman languages II, 179-200. Leiden: Brill.

Beckwith, Christopher I. (2008) "Old Chinese loans in Tibetan and the non-uniqueness of "SinoTibetan”". In Medieval Tibeto-Burman languages III, 161-201. Leiden: Brill. 
Behr, Wolfgang (2002) “Review [of Sūn Y. 2000]”. Revue Bibliographique de Sinologie Nouvelle série 20, 289-290.

Benedict, Paul K. (1972) Sino-Tibetan: a conspectus. London: Cambridge University Press.

Bodman, Nicholas C. (1980) "Chinese and Sino-Tibetan: data towards establishing the nature of their relationship". In Frans van Coetsem, ed. Contributions to historical linguistics, 34-199. Leiden: E. J. Brill.

Bodman, Nicholas C. (1985) "Evidence for 1 and $\mathrm{r}$ medials in Old Chinese and associated problems". In Grahem Thurgood, James A. Matisoff, and David Bradley, eds. Linguistics of the Sino-Tibetan area: the state of the art, 146-167. Canberra: Department of Linguistics, Research School of Pacific Studies, Australian National University.

Boltz, William G. (1979) "Review [of Schüssler 1976]”. Journal of the American Oriental Society 99, 2, 328-330.

Boltz, William G. (1993) "Notes on the reconstruction of Old Chinese". Oriens extremus: Zeitschrift für Sprache, Kunst und Kultur der Länder des Fernen Ostens 36, 2, 185-207.

Boltz, William G. (2002) "Review [of Zhengzhang 2000]”. Cahiers de Linguistique - Asie Orientale $31,105-116$.

Cài, Yǒng-guì (2005) "Fù-fŭ-yīn shēng-mǔ: Yí gè bìng-bù-kě-xìn de jiă-shuō". Níng-xià dà-xué xuébào (rén-wén-shè-huì-kē-xué-băn) 27, 2, 5-11.

Chén, Băo-yà; Wāng, Fēng (2012) "Hàn-yǔ Zàng-miăn-yǔ tóng-yuán de liăng gè cí-huì yǒu-jiē fên-bù zhèng-jù”. Yún-nán shī-fàn dà-xué xué-bào (zhé-xué-shè-huì-kē-xué-băn) 44, 5, $13-17$.

Chén, Fù-huá (1983) Hàn-yǔ yīn-yùn-xué jī-chū. Beijing: China Renmin University Press. [(2002) (dì-2 -băn xiū-dìng-běn)]

Chén, Fù-huá; Hé, Jiǔ-yíng (1987) Gŭ-yùn tōng-xiăo. Beijing: China Social Sciences Press.

Chén, Rén-qiū (1995) Hàn-yǔ yīn-yùn-xué gài-yào. Chengdu: Sichuan University Press.

Chén, Xīn-xióng (2003) "Méi Zǔ-lín yǒu Zhōng-guó tè-sè de Hàn-yǔ lì-shǐ yīn-yùn-xué jiăng-cí zhìyí”. Yǔ-yán yán-jiū 23, 1, 28-36.

Chén, Xīn-xióng (2008) “Zhèng-zhāng Shàng-fāng shī-jīng de gǔ-yīn-xué jià-zhí lùn-shù”. Zhōng-guó yй-yán-xué 1, 11-14.

Chén, Xīn-xióng (2009) “Chén xù”. Yīn-yùn-xuéfāng-fă-lùn tăo-lùn-jí, 4-6. Beijing: The Commercial Press.

Chén, Zhōng-mǐn (2005) "Yǒu-guān lì-shǐ yǔ-yán-xué de yì-xiē jī-bēn wèn-tí". Yǔ-yán yán-jiū 25, 3, 69-76.

Chéng, Yuè (2018) "J̄i-yú nèi-zhèng cái-liào duì shàng-gǔ-Hàn-yǔ gòu-nī xīn-lùn xiāo-yào fên-bù de kăo-chá yǔ tăo-lùn”. Hú-běi dà-xué xué-bào (zhé-xué-shè-huì-kē-xué-băn) 45, 1, 155-164.

Coblin, Weldon S. (1986) A Sinologist's handlist of Sino-Tibetan lexical comparisions. Nettetal: Steyler Verlag.

Comrie, Bernard; Corbett, Greville G., eds. (1993) The Slavonic languages. London: Routledge.

Cuī, Jīn-míng (2012) "Shì-xī Hàn-Zàng bǐ-jiào duì shàng-gǔ-yīn yán-jiū de jià-zhí". Xī-běi mín-zú dàxué xué-bào (zhé-xué-shè-huì-kē-xué-băn) 2012, 4, 184-188.

Cuī, Jīn-míng (2013) "Shì-xī Hàn-Zàng bǐ-jiào yǔ-yán-xué de fā-zhăn duì shàng-gǔ-yīn yán-jiū de jiàzhí”. Hàn-zì wén-huà 2013, 2, 54-57.

Cuī, Jīn-míng; Liú, Kūn (2013) "Lǐ Fāng-guì yǔ Zhèng-zhāng Shàng-fāng shàng-gǔ fù-fǔ-yīn bǐ-jiào yán-jiū”. Xī-běi mín-zú dà-xué xué-bào (zhé-xué-shè-huì-kē-xué-băn) 2013, 2, 101-105.

Cuī, Jīn-míng (2015) "Shì-xī shàng-gǔ yǔ bí-yīn jié-hé de fù-fǔ-yīn de nǐ-yīn wèn-ti'". Yǔ-yán kē-xué $14,2,131-140$.

Cuī, Yàn (2007) "Shàng-gǔ 2-děng r-jiè-yīn gòu-nǐ xiăo-yì”. Hú-běi dà-xué xué-bào (zhé-xué-shè-huìkē-xué-băn) 35, 4, 21-24. 
Dài, Qìng-xià (2015) “Hàn-Zàng-yǔ yán-jiū de 4 gè kùn-huò jí qí qián-jǔng”. Mín-shú diăn-jí wén-zì yán-jīu 16 (2015, 2), 33-39.

Dīng, Bāng-xīn (1978) "Lùn shàng-gǔ-yīn zhōng dài 1 de fù-shēng-mǔ”. Qù Wàn-lǐ xiān-shēng 7-zhì róng-qìng lún-wén-jí, 601-617. Taipei: Linking Publishing.

Dīng, Bāng-xīn (1979) “Shàng-gǔ-Hàn-yǔ de yīn-jié jié-gòu”. Lì-shǐ yǔ-yán yán-jiū-suǒ jí-kān, 50, 4, 717-739.

Dīng, Bāng-xīn (1981) "Hàn-yǔ shēng-diào yuán-yú yùn-wěi shuō zhījiăn-tăo". Zhōng-yāng yán-jiūyuàn guó-jì Hàn-xué huì-yì lùn-wén-jí: yǔ-yán-wén-zì-zŭ, 267-287. Taipei: Academia Sinica.

Dīng, Bāng-xīn (2003) "Píng Méi Zǔ-lín shì-jiàn”. Nán-kāi yǔ-yán xué-kān 2 (2003), 131-134.

Dīng, Bāng-xīn (2015) Yìn-yùn-xué jiăng-yì. Beijing: Peking University Press.

Dīng, Qǐ-zhèn (2000) Lùn gǔ wú fù-fǔ-yīn shēng-mǔ. Macau: Macau Linguistic Society.

Dīng, Qǐ-zhèn (2005) “Fù-fŭ-yīn shuō de yì-xiē wèn-tí”. Yǔ-yán jiào-xué yǔ yán-jiū 2006, 5, 7-14.

Dīng, Qî-zhèn (2016) Hàn-yŭ fù-fǔ-yīn shuō biàn-zhèng. Beijing: Zhonghua Book Company.

Dǒng, Jiàn-jiāo (2003) “Guān-yú zhēng-yuè jí qí-tá”. Gǔ-Hàn-yǔ yán-jiū 2003, 4, 20-24.

Dù, Chún-zǐ (2003a) "Dùi dòng-bǔ jié-gòu chăn-shēng yú 6-cháo shuō zhī xiàn-yí”. Yǔ-wén yán-jiū 2003, 4, 32-36.

Dù, Chún-zì (2003b) "Dùi shā hé sǐ xíng-shì biāo-zhì què-lì yǔ yīng-yòng de zhuī-zōng fên-xī: Jiān píng Méi Zǔ-lín duì dòng-bǔ jié-gòu de yán-jiū”. Gǔ-Hàn-yǔ yán-jiū 2003, 4, 2-12.

Féng, Zhēng (2008) "Dì-3-cì gǔ-yīn-xué dà-biàn-lùn". Hàn-zì wén-huà 2008, 4, 7-23.

Féng, Zhēng (2009a) "Hàn-Zàng yǔ bǐ-jiào yǔ-yán-xué zhòng-yào lùn-zhù shù-píng yǔ chū-bù yánjiū”. Hàn-zì wén-huà 2009, 1, 20-47.

Féng, Zhēng (2009b) "Lùn gòu-nǐ shàng-gǔ fù-shēng-mǔ de yuán-zé yǔ fāng-fă". Hàn-zì wén-huà 2009, 5, 55-56.

Féng, Zhēng (2010-2011) “20-shì-jì Hàn-yǔ lì-shǐ yīn-yùn-xué yán-jiū de 100 xiàng xīn-fā-xiàn yǔ xīnjìn-zhăn”. Hàn-zì wén-huà 2010, 5, 5-19 + 2010, 6, 7-25 + 2011, 1, 40-44.

Féng, Zhēng (2011) "Lùn gǔ-Hàn-yǔ hé Zàng-yǔ tóng-yuán-cí bǐ-jiào de ȳin-yùn kuàng-jià mó-shì”. Hàn-zì wén-huà 2011, 6, 43-50.

Féng, Zhēng (2014) "Hàn-yǔ zì-diăn gǔ-yīn biāo-zhù de zhòng-dà tū-pò". Hàn-zì wén-huà 2014, 4, 91-93.

Féng, Zhēng (2017) "Guān-yú Zhèng-zhāng Shàng-fāng, Bái Yī-píng Shā-jiā-ěr hé Sī-tǎ-luó-sī-jīn 3 jiā shàng-gǔ-yīn tǐ-xì zhōng-de suǒ-wèi yí bù duō yuán-yīn wèn-ti'”. Nán-yáng shī-fàn xué-yuàn xué-bào (shè-huì-kē-xuē-băn) 16, 4, 1-13.

Gao, Jingyi [= Gāo, Jīng-ȳi] (2012) "Official colours of Chinese regimes: a panchronic philological study with historical accounts of China". Trames 16, 3, 237-285.

Gao, Jingyi (2012-2013) "Huns and Xiongnu identified by Hungarian and Yeniseian shared etymologies". Central Asiatic Journal 56, 41-48.

Gao, Jingyi (2014) "Rhyme correspondences between Sinitic and Uralic languages: on the example of the Finnish -ala and -aja rhymes". Linguistica Uralica 50, 2, 94-108.

Gao, Jingyi (2017) "Xia and Ket identified by Sinitic and Yeniseian shared etymologies". Central Asiatic Journal 60, 1-2, 51-58.

Gao, Jingyi (2018) "Veel hiina ja soome-ugri keelte ühiseid etümoloogiaid riimivastavuse näitel". Idakiri: Eesti Akadeemilise Orientaalseltsi aastaraamat 2018, 71-80.

Gao, Jingyi (2019a) "On etymology of Finnic term for 'sky". Archaeoastronomy and Ancient Technologies 7, 2, 5-10.

Gao, Jingyi (2019b) "Karl August Hermanni hiina-soome-eesti keelevõrdlus ning kehtivad ja kehtetud etümoloogiad parandustega". Journal of Estonian and Finno-Ugric Linguistics 10, 2, 45-58. 
Gao, Jingyi (2019c) "Hiina etnoloogilise, poliitilise ja keelelise ajaloo ülevaade". Idakiri: Eesti Akadeemilise Orientaalseltsi aastaraamat 2019, 141-172.

Gao, Jingyi (2020a) "Sino-Uralic etymology for 'Jupiter, year' supported by rhyme correspondence". Archaeoastronomy and Ancient Technologies 8, 1, 1-11.

Gao, Jingyi (2020b) "On Etymology of Sinitic, Indo-European and Uralic terms for 'star' supported by regular sound correspondences". Archaeoastronomy and Ancient Technologies 8, 2, 29-40.

Gao, Jingyi; Tender, Tõnu (2020) "Sino-Uralic etymology for 'moon, month' supported by rhyme correspondence". Archaeoastronomy and Ancient Technologies 8, 1, 60-68.

Gāo, Jīng-yī (2008) Hàn-yǔ yǔ běi-Ōu yǔ-yán. Beijing: China Social Sciences Press.

Gāo, Jīng-yī (2014) “Hànyǔ yǔ Wū-lā-ěr yǔ-yán tóng-yuán guān-xì gài-lù”. In Zhāng Wéi-jiā, ed. Dì-yù wén-huà yǔ Zhōng-guó yǔ-yán, 36-90. Beijing: The Commercial Press.

Gāo, Yǒng-ān (2008) “Shì yuán-zé zhī zhēng hái shì Zhōng xī zhī zhēng”. Hú-běi dà-xué xué-bào (zhéxué-shè-huì-kē-xué-băn) 35, 2, 64-69.

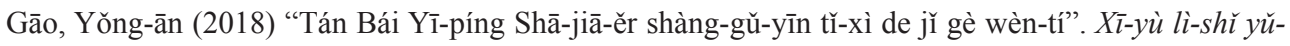
yán yán-jiū ji-kān 10, 391-396.

Gěng, Zhèn-shēng (2003) “Lùn xié-shēng yuán-zé”. Yǔ-yán kē-xué 2, 5, 10-28.

Gěng, Zhèn-shēng (2004) 20-shì-jì Hàn-yǔ yīn-yùn-xué fāng-fă-lùn. Beijing: Peking University Press.

Gěng, Zhèn-shēng (2005) "Hàn-yǔ yīn-yùn shǐ yǔ Hàn-Zàng-yǔ de lì-shǐ bǐ-jiào". Hú-běi dà-xué xuébào (zhé-xué-shè-huì-kē-xué-băn) 32, 1, 81-88.

Gěng, Zhèn-shēng (2016) Yìn-yùn-xué yán-jiū fāng-fă dăo-lùn. Beijing: Peking University Press.

Gong, Hwang-cherng [= Gōng, Huáng-chéng] (1980) "A comparative study of the Chinese, Tibetan and Burmese vowel systems". Bulletin of the Institute of History and Philology Academia Sinica 51, 3, 455-490.

Gong, Hwang-cherng (1995) “The system of finals in Proto-Sino-Tibetan”. In William S.-Y. Wang, ed. The Ancestry of the Chinese language, 41-92. Berkeley: Journal of Chinese Linguistics Project on Linguistic Analysis.

Gōng, Huáng-chéng (2006) "X̄̄-fāng de lì-shǐ bǐ-jiào yǔ-yán-xué yǔ Hàn-Zàng-yǔ bǐ-jiào yán-jiū”. Yǔyán-xué lùn-cóng 35, 280-295.

Guō, Xī-liáng (1986) Hàn-zì gǔ-yīn shǒu-cè. Beijing: Peking University Press.

Guō, X̄̄-liáng (1997) “Jiè-cí yú de qǔ-yuán hé fā-zhăn”. Zhōng-guó yǔ-wén 1997, 2, 131-138.

Guō, Xī-liáng (2002) "Lì-shǐ yīn-yùn-xué yán-jiū zhōng-de jǐ gè wèn-tí”. Gǔ-Hàn-yǔ yán-jiū 2002, 3, 2-9. Guō, Xī-liáng (2003) "Yīn-yùn wèn-tí dá Méi Zǔ-lín”. Gǔ-Hàn-yŭ yán-jīu 2003, 3, 2-17.

Guō, Xī-liáng (2005) "Hàn-yǔ jiè-cí yú qǐ-yuán yú Hàn-Zàng-yǔ shāng-què”. Zhōng-guó yǔ-wén 2005, 4, 341-345.

Guō, X̄̄-liáng (2007a) “Měi-zì néng guī-rù wēi-bù ma?”. Yǔ-yán-xué lùn-cóng 35, 296-302.

Guō, Xī-liáng (2007b) "Yān bó shí duàn jīng shěn". Hú-běi dà-xué xué-bào (zhé-xué-shè-huì-kē-xuébăn) 34, 4, 17-18.

Guō, Xī-liáng (2008) "Hàn-Zàng zhū yǔ-yán bǔ-jiào yán-jiū chú-yì”. Zhōng-guó yǔ-yán-xué 1, 1-10.

Guō, Xī-liáng (2009) “Gūō xù”. Yìn-yùn-xué fāng-fă-lùn tăo-lùn-jí, 1-3. Beijing: The Commercial Press. Guō, Xī-liáng (2010) Hàn-zì gǔ-yīn shǒu-cè (zēng-dìng-běn). Beijing: The Commercial Press.

Guō, Xī-liáng (2011) “Zài tán měi-zì néng guī-rù wēi-bù?”. Zhōng-guó yǔ-yán-xué 5, 1-6.

Guō, Xī-liáng (2014) "Tán-tan gǔ-yīn-xué yán-jiū de 10 nián lùn-zhēng”. Zhōng-guó yīn-yùn-xué jì Huáng Diăn-chéng xué-shù sī-xiăng guó-jì xué-shù yán-tăo-huì lùn-wén-jí, 27-31. Xiamen: Xiamen University Press. 
Guō, Xī-liáng (2017) “Yě tán gǔ-Hàn-yǔ fù-fǔ-yīn wèn-tí”. In Guō Xī-liáng, Hàn-yǔ yán-jiū cún-găo, 334-349. Beijing: Zhonghua Book Company.

Handel, Zev (2002) "Rethinking the medials of Old Chinese: where are the r's?". Cahiers de Linguistique - Asie Orientale 31, 1, 3-32.

Handel, Zev (2009) Old Chinese medials and their Sino-Tibetan origins: a comparative study. Taipei: Institute of Linguistics, Academia Sinica.

Harbsmeier, Christoph (2016) "Irrefutable conjectures: a review of William H. Baxter and Laurent Sagart, Old Chinese: a new reconstruction”. Monumenta Serica 64, 2, 445-504.

Hé, Jiǔ-yíng (1988) Gǔ-Hàn-yŭ yīn-yùn-xué shù-yào. Hangzhou: Zhejiang Press of Classics. [(2010) Beijing: Zhonghua Book Company]

Hé, Jiǔ-yíng (1991) Shàng-gǔ-yīn. Beijing: The Commercial Press.

Hé, Jiǔ-yíng (2004) “Hàn-yǔ hé qīn-shǔ yǔ-yán bǐ-jiào yán-jiū de jī-běn yuán-zé”. Yǔ-yán-xué lùn-cóng $29,12-66$.

Hé, Jiǔ-yíng (2005) “Suǒ-wèi qīn-shǔ yǔ-yán de cí-huì bǐ-jiào wèn-tí”. In Dǒng Kūn; Féng Zhēng, eds. Yīn shù xīn lùn: Qìng-zhù Shào Róng-fên xiān-shēng 80 shòu-chén xué-shù lùn-wén-jí, 30-34. Beijing: Xueyuan Press.

Hé, Jiǔ-yíng (2014-2015) “Chóng-jiàn Huá-Yí yǔ-xì de lǐ-lùn hé zhèng-jù". Mín-shú diăn-jí wén-zì yán-jīu 14 (2014, 2), 1-43 + 16 (2015, 2), 1-31.

Hé, Jiǔ-yíng (2017) “Chóng-jiàn Huá-Yí yǔ-xì de lǐ-lùn hé zhèng-jù xù”. Mín-shú diăn-jí wén-zì yán-jiū 19 (2017, 1), 2-17.

Hé, Kūn-yì (2009) “Zhū-jiā zhì-Méi-wén shù-yào". Yīn-yùn-xué fāng-fă-lùn tăo-lùn-jí, 234-248. Beijing: The Commercial Press.

Hill, Nathan W. (2019) The historical phonology of Tibetan, Burmese, and Chinese. Cambridge: Cambridge University Press.

Hú, Ān-shùn (1998) Hàn-yǔ yīn-yùn-xué tōng-lùn. Xi’an: Shaanxi People's Education Press.

Hú, Ān-shùn (2002) Yīn-yùn-xué tōng-lùn. Beijing: Zhonghua Book Company. [(2003) (dì-2-băn)]

Hú, Jì-míng (2005) "Jiù Wáng Niàn-sūn Guăng yă shū zhèng yán-jiū tóng-yuán-cí de fāng-fã yǔ Méi Zǔ-lín shāng-què”. Chóng-qìng sān-xiá xué-yuàn xué-bào 21, 6, 60-67.

Huà, Xué-chéng; Băi, Yà-dōng; Wáng, Zhì-qún; Zhào, Qí-dòng; Zhèng, Dōng-zhēn (2003) "Jiù Wáng Niàn-sūn de tóng-yuán-cí yán-jiū yǔ Méi Zǔ-lín jiào-shòu shāng-què”. Gǔ-Hàn-yǔ yán-jiū 2003, 1, 8-13.

Huáng, Shù-xiān (2005) “Cóng hé-xīn-cí kàn Hàn-Miăn-yǔ guān-xì”. Yǔ-yán kē-xué 4, 3, 90-108.

Huáng, Yì-qīng (2004) "Lùn shàng-gǔ yá-hóu-yīn xiàng chǐ-tóu-yīn de yăn-biàn jí gǔ míng-mǔ yīnzhì”. Gŭ-Hàn-yŭ yán-jiū 2004, 1, 20-27.

Huáng, Yì-qīng (2005) “Lùn xié-shēng de jiàn-bié jí shēng-fú de lì-shǐ yīn-biàn”. Gǔ-Hàn-yǔ yán-jīu 2005, 3, 22-29.

Huáng, Yì-qīng (2013-2014) “Cóng yīn-yì guān-xì kàn zhōng-gǔ lái-mǔ-zì de shàng-gǔ-yīn lái-yuán”. Mín-shú diăn-jí wén-zì yán-jiū 12 (2013, 2), 195-205 + 13 (2014, 1), 133-141.

Jacques, Guillaume (2015) "On the cluster *sr- in Sino-Tibetan". Journal of Chinese Linguistics 43, 1a, 215-223.

Jaxontov, Sergej E. (1963) “Sočetanija soglasnyx v drevnekitajskom jazyke”. Trudy dvadcat' pjatogo meždunarodnogo kongressa vostokovedov, t. 5, 89-95. Moskva: Izdatel'stvo vostočnoj literatury. [Formal publication, Russian version of Yahkontov 1960]

Jiăn, Qǐ-xián (2012) Yìn-yùn-xué jiào-chéng zēng-dìng-bèn. Chengdu: Bashu Book Company. 
Jīn, Lǔ-xīn (2002) Shàng-gǔ Hàn-yǔ yīn-xì. Hefei: Huangshan Book Company.

Jīn, Lǐ-xīn (2003) "Hàn-Zàng-yǔ de yǔ-yīn duì-yìng yǔ yǔ-yīn xiāng-sì”. Mín-zú yǔ-wén 2003, 3, 11-18.

Jīn, Lǐ-xīn (2004) "Yǔ xiăo-mǔ xiāng-guān de yì-xiē xié-shēng guān-xì hé xiăo-mǔ dú-yīn”. Wēn-zhōu shī-fàn xué-yuàn xué-bào (zhé-xué-shè-huì-kē-xué-băn) 25, 6, 14-19.

Jīn, Lǐ-xīn (2005a) “Shàng-gǔ Hàn-yǔ *m-qián-zhuì de yì-yì”. Yǔ-yán yán-jiū 25, 1, 73-77.

Jīn, Ľ̌̀-xīn (2005b) "Hàn-Zàng-yŭ de wán-chéng-tǐ hòu-zhuì *-s". Mín-zú yǔ-wén 2005, 2, 1-6.

Jīn, Lǐ̀-xīn (2013) Shàng-gǔ yīn-luè. Hefei: Huangshan Book Company.

Jīn, Lǐ-xīn (2016) “Gǔ-yīn gòu-nǐ de yí gè wèn-tí”. Huá-zhōng guó-xué 2016, 1, $23-29$.

Karlgren, Bernhard (1934) "Word families in Chinese". Bulletin of the Museum of Far Eastern Antiquities 5, 9-120.

Karlgren, Bernhard (1954) "Compendium of phonetics in Ancient and Archaic Chinese". Bulletin of the Museum of Far Eastern Antiquities 26, 211-367.

Karlgren, Bernhard (1957) "Grammatica Serica Recensa". Bulletin of the Museum of Far Eastern Antiquities 29, 1-332.

Lài, Yún-fān (2013) "É-rè-huà de fǔ-yīn chóng-dié”. Mín-zú yǔ-wén 2013, 6, 12-18.

Léi, Táng-xún (2018) "Shàng-gǔ-Hàn-yǔ gòu-nǐ xīn-lùn yīn-yì guān-xì zhǐ-wù”. Xī-yù lì-sh ̌̌ yǔ-yán yán-jiü jí-kān 10, 397-408.

Lemon, George W. (1783) English etymology; or a derivative dictionary of the English language. London: G. Robinson.

Lí, Xīn-yǔ (2009) “Dú Féng Zhēng jiào-shòu dì-3-cì gǔ-yīn-xué dà-biàn-lùn jiăng-cí”. Zhōng-guó yǔyán-xué 3, 1-13.

Lǐ, Băo-jiā (1990) "Shì-lùn yuán-shǐ Huá-Xià-yǔ de lì-shǐ bèi-jǐng". Yǔ-yán-xué tōng-xùn 1990, 1/2, 1-2.

Lǐ, Băo-jiā (1998) Dāng-dài Zhōng-guó yīn-yùn-xué. Guangzhou: Guangdong Education Press.

Lǐ, Fāng-guì (1971) "Shàng-gǔ-yīn yán-jiū". Qīng-huá xué-bào xīn-9, 1/2, 1-61. [Monograph edition (1980). Beijing: The Commercial Press]

Lǐ, Jiàn-qiáng (2007) “Duì fù-fŭ-yīn xué-shuō de yí-wèn”. Hú-běi dà-xué xué-bào (zhé-xué-shè-huì-kēxué-băn) 35, 2, 64-69.

Lǐ, Jiàn-qiáng (2015) Lái-mǔ-zì ji xiāng-guān de shàng-gǔ-yīn yán-jiū. Beijing: China Social Sciences Press.

Lǐ, Jiàn-qiáng (2017) "Cóng Huáng Kăn Shēng yùn luè shuō kàn dāng-qián fù-shēng-mǔ wèn-tí de lùnzhēng”. Cháng-jiāng xué-shù 2017, 1, 115-120.

Lǐ, Juān-juān (2017) "Lùn shàng-gǔ yùn-bù yǔ rù-shēng yùn-wěi de qīng-zhuó". Hán-dān xué-yuàn xué-bào 27, 2, 46-51.

Lǐ, Kāi (2006) "Xiàn-dài xué-shù-shǐ guān-yú gǔ-yīn-xué de 3 cì dà-tăo-lùn”. Nán-kāi yǔ-yán xué-kān $7(2006,1), 11-20$.

Lǐ, Xiāng (2003) “Guān-yú qù-shēng yuán-yú -s-wěi de ruò-gān zhèng-jù de shāng-què”. Yǔ-yán-xué lùn-cóng 28, 34-42.

Lǐ, Xīn-kuí (1979) Gǔ-yīn gài-shuō. Guangzhou: Guangdong People’s Press.

Lǐ, Xīn-kuí (1986) Hàn-yǔ yīn-yùn-xué. Beijing: Beijing Press.

Lĭ, Wú-wèi (2006) Hàn-yŭ yīn-yùn-xué tōng-lùn. Beijing: Higher Education Press.

Lín, Qìng-xūn (2009) “Chuán shén-me gèi xià-yí-bàng”. Yìn-yùn-xué fāng-fă-lùn tăo-lùn-jí, 249-262. Beijing: The Commercial Press.

Lín, Tāo; Gěng, Zhèn-shēng (2004) Yīn-yùn-xué gài-yào. Beijing: The Commercial Press.

Liú, Kūn (2011) "Xiē-shēng-zì yǔ shàng-gŭ fù-shēng-mǔ yán-jiū”. Xī-běi gōng-yè dà-xué xué-bào (shèhuì-kē-xué-băn) 31, 2, 81-84. 
Liú, Lún-xīn (2001) Yīn-yùn-xué jū-chǔ jiào-chéng. Beijing: China Social Sciences Press.

Liú, Qín (2014) "Zhèng-zhāng Shàng-fāng shàng-gǔ Hàn-yǔ fù-shēng-mǔ tǐ-xì yán-jiū". Níng-xià dàxué xué-bào (rén-wén-shè-huì-kē-xué-băn) 36, 4, 1-12.

Liú, Xiăo-nán (2007) Hàn-yǔ yīn-yùn-xué yán-jiū jiào-chéng. Beijing: Peking University Press. [(2016) (dì-2-băn)]

Liú, Xiăo-nán (2011) Yìn-yùn-xué dú-běn. Shanghai: Shanghai Jiao Tong University Press.

Lóng, Zhuāng-wěi (2005) Hàn-yǔ yīn-yùn-xué. Beijing: Yuwen Press.

Lǔ, Guó-yáo (2003) “Lùn lì-shǐ wén-xiàn kăo-zhèng-fă yǔ lì-shǐ bǐ-jiào-fă de jié-hé”. Gǔ-Hàn-yǔ yánjiū 2003, 1, 1-7.

Lǔ, Guó-yáo (2007) “Lùn Hàn-yǔ yīn-yùn-xué de yán-jiū fāng-fã hé wǒ de jié-hé-lùn”. Hàn-yǔ xué-bào 2007, 2, 2-10.

Luó, Yǒng-xiàn (2007) “Shàng-gǔ Hàn-yǔ de yùn-wěi *-1 yǔ *-r”. Dōng-fāng yǔ-yán-xué 2, 177-184.

Mă, Kūn (2017) "Lì-shǐ bǐ-jiào xià-de shăng-gǔ Hàn-yǔ gòu-ň̌”. Zhōng-guó yǔ-wén 2017, 4, 496-509.

Mài, Yún (2003a) "Pān Wù-yún shàng-gǔ Hàn-yǔ fù-fǔ-ȳin shēng-mǔ yán-jiū shù-píng". Nán-kāi yǔyán xué-kān 2 (2003), 135-141.

Mài, Yún (2003b) "Hàn-yǔ lì-shǐ yīn-yùn yán-jiū zhōng ruò-gān wèn-tí zhī wǒ jiàn”. Gǔ-Hàn-yǔ yánjiū 2003, 4, 13-19.

Mài, Yún (2005) "Hàn-yǔ shǐ yán-jiū zhōng-de jiă-shè yǔ zhèng-míng”. Yǔ-yán yán-jiū 25, 2, 7-15.

Mài, Yún (2009) Yìn-yùn-xué gài-lùn. Nanjing: Jiangsu Education Press.

Matisoff, James A. (2003) Handbook of Proto-Tibeto-Burman. Berkeley: University of California Press.

Mă-dì-suǒ-fū [= Matisoff, James A.] (2006) "Lì-shǐ yǔ-yán-xué yán-jiū bú shì Ào-lín-pǐ-kè jìng-sài”. Yǔ-yán-xué lùn-cóng 34, 346-359.

Mă-dì-suǒ-fū (2007) “Hàn-Zàng-yǔ yán-jiū 40 nián 1968-2007”. Yǔ-yán kē-xué 3, 3, 22-24.

Mei, Tsu-lin [= Méi, Zǔ-lín] (1979) "Sino-Tibetan 'year', 'month', 'foot' and 'vulva'”. Tsing-Hua Journal of Chinese Studies New Series 12, 1, 117-132.

Méi, Zǔ-lín (1991) “Cóng Hàn-dài de dòng-shā dòng-š̌ lái kàn dòng-bǔ jié-gòu de fā-zhăn”. Yǔ-yánxué lùn-cóng 16, 112-136.

Méi, Zǔ-lín (2000) Méi Zŭ-lín yǔ-yán-xué lùn-wén-jí. Beijing: The Commercial Press.

Méi, Zǔ-lín (2002) "Yǒu Zhōng-guó tè-sè de Hàn-yǔ lì-shǐ yīn-yùn-xué”. Journal of Chinese Linguistics / Zhōng-guó yǔ-yán-xué-bào 30, 2, 211-240.

Méi, Zǔ-lín (2003) "Bǐ-jiào-fă zài Zhōng-guó, 1926-1998”. Yǔ-yán yán-jiū 23, 1, 16-27.

Méi, Zǔ-lín (2004) “Jiè-cí yú zài jiă-gǔ-wén hé Hàn-Zàng-yǔ lǐ-de qǔ-yuán”. Zhōng-guó yǔ-wén 2004, $4,323-332$.

Méi, Zǔ-lín (2006) “Cóng Chǔ-jiăn (měi)-zì lái kàn zhī-wēi-liăng-bù de fēn-yě”. Yǔ-yán-xué lùn-cóng $32,173-192$.

Méi, Zǔ-lín (2007) “Mǔn-yǔ yú-yù-liăng-zì yáng-diào h-shēng-mǔ de lái-yuán”. Fāng-yán 2007, 4, 289-295.

Méi, Zǔ-lín (2008a) "Jiă-gǔ-wén lǐ-de jǐ gè fü-fǔ-yīn shēng-mǔ”. Zhōng-guó yǔ-wén 2008, 3, 195-207.

Méi, Zǔ-lín (2008b) “Shàng-gǔ-Hàn-yǔ dòng-cí zhuó-qīng-bié-yì de lái-yuán”. Mín-zú yǔ-wén 2008, 3, 3-20.

Méi, Zǔ-lín (2013) "Yuán-shǐ-Hàn-Zàng-yǔ dòng-cí hòu-zhuì *-s zài shàng-gǔ-Hàn-yǔ lǐ-de yí-jì". Lìshǐ yǔ-yán yán-jiū 6, 1-10.

Méi, Zǔ-lín (2015) "Bá Yán Xué-qún xiān-shēng gěi gǔ-Hàn-yǔ fù-shēng-mǔ lùn-wén-jí (1998) xiě de xù:”. Yǔ-yán yán-jiū 35, 3, 125-127.

Miller, Roy A. (1974) "Sino-Tibetan: inspection of a conspectus". Journal of the American Oriental Society 94, 2, 195-209.

Norman, Jerry (1988) Chinese. Cambridge: Cambridge University Press. 
Norman, Jerry; Mei, Tsu-lin (1976) “The Austroasiatics in Ancient South China: some lexical evidence”. Monumenta Serica 32, 274-301.

Pān, Băi-nián (2009) "Méi Zǔ-lín Zhōng-guó yǔ-yán-xué de chuán-tǒng hé chuàn-xīn shāng-què". Yīnyùn-xué fāng-fă-lùn tăo-lùn-jí, 195-217. Beijing: The Commercial Press.

Pān, Wù-yún (2000) Hàn-yǔ lì-shǐ yīn-yùn-xué. Shanghai: Shanghai Education Press.

Pān, Wù-yún (2005a) “Zì-shū-pài yǔ cái-liào-pài”. In Dǒng Kūn; Féng Zhēng, eds. Yīn shǐ xīn lùn: Qing-zhù Shào Róng-fên xiān-shēng 80 shòu-chén xué-shù lùn-wén-jí, 368-375. Beijing: Xueyuan Press.

Pān, Wù-yún (2005b) "Hàn-yǔ fāng-yán-xué yǔ yīn-yùn-xué yán-jiū fāng-xiàng de qián-zhān”. Jì-nán xué-bào (zhé-xué-shè-huì-kē-xué-băn) 2005, 5, 104-107.

Pān, Wù-yún (2007) “Shàng-gǔ-Hàn-yǔ yùn-wěi *-1 yǔ *-r”. Mín-zú yǔ-wén 2007, 1, 9-17.

Pān, Wù-yún (2010) "Lì-shǐ chéng-cì fēn-xī de ruò-gān lǐ-lùn wèn-tî”. Yǔ-yán yán-jiū 30, 2, 1-15.

Pān, Wù-yún (2011) "Miàn-xiàng jīng-yàn kē-xué de dì-3-dài yīn-yùn-xué”. Yǔ-yán yán-jīu 31, 1, 59-63.

Pān, Wù-yún (2018) “Shàng-gǔ-Hàn-yǔ bí-yīn kăo”. Mín-zú yǔ-wén 2018, 4, 3-9.

Páng, Guāng-huá (2005) Lùn Hàn-yǔ shàng-gǔ wú fù-fǔ-yīn shēng-mǔ. Beijing: China Philology and History Press.

Páng, Guāng-huá (2011) “Lùn shàng-gǔ-yīn gē-bù bú dài [-r] huò [-1] wěi”. Zhōng-guó yǔ-yán-xué 5, 7-15. Pulleyblank, Edward G. (1962) "The consonantal system of Old Chinese”. Asia Major New Series 9, 58-144; 206-265. [Chinese monograph edition (1999) Pú-lì-běn (zhù); Pān Wù-yún, Xú Wénkān (yì). Shàng-gǔ-Hàn-yŭ de fǔ-yīn xì-tǒng. Beijing: Zhonghua Book Company.]

Pulleyblank, Edward G. (1965) “The transcription of Sanskrit k and kh in Chinese”. Asia Major New Series 11, 199-210.

Pulleyblank, Edward G. (1977-1978) “The final consonants of Old Chinese”. Monumenta Serica 33, 180-206. Qí, Xiăo-yàn (2018) "Cóng xiān-Qín yùn-wén kàn Bái Ȳ̄-píng Shā-jiā-ěr duì gē-yuè-yuán-3-bù de zài fēn-bù jí gòu-nǐ”. Yǔ-yán yán-jiū 38, 4, 86-96.

Qiáo, Quán-shēng (2020) “Zhōng-guó yīn-yùn-xué yán-jiū 70 nián”. Shăn-xī shī-fàn dà-xué xué-bào (zhé-xué-shè-huì-kē-xué-băn) 49, 1, 29-49.

Qú, Ǎi-táng; Jìn, Sōng (2013) “Lùn Hàn-Zàng-yǔ yǔ-yán lián-méng”. Mín-zú yǔ-wén 2013, 5, 13-24.

Rask, R[asmus] K. (1818) Undersögelse om det gamle Nordiske eller Islandske Sprogs Oprindelse. Kjöbenhavn (Copenhagen): Gyldendal.

Sagart, Laurent (1999) The roots of Old Chinese. Amsterdam: John Benjamins. [Chinese translation (2019) Shā-jiā-ěr (zhù), Gōng Qún-hǔ (yì), Shàng-gǔ-Hàn-yǔ cí-gēn. Shanghai: Shanghai Education Press]

Schuessler, Axel (1974a) "Final -1 in Archaic Chinese". Journal of Chinese Linguistics 2, 1, $78-87$.

Schuessler, Axel (1974b) "R and 1 in Archaic Chinese". Journal of Chinese Linguistics 2, 2, 186-199.

Schuessler, Axel (2003) "Multiple origins of the Old Chinese lexicon". Journal of Chinese Linguistics $31,1,1-71$.

Schuessler, Axel (2009) Minimal Old Chinese and Later Han Chinese: a companion to Grammata Serica Recensa. Honolulu: University of Hawai'i Press.

Schüssler, Axel [= Schuessler, Axel] (1976) Affixes in Proto-Chinese. Wiesbaden: Franz Steiner Verlag. Shī, Xiàng-dōng (2000) Hàn-yǔ hé Zàng-yǔ tóng-yuán tǐ-xì de b̌̌-jiào yán-jiū. Beijing: Sinolingua.

Shī, Xiàng-dōng (2007) "Hàn-Zàng bǐ-jiào zhōng-de lì-shǐ chéng-cì yǔ jiè-cí wèn-tí". Yǔ-yán kē-xué $6,6,54-59$.

Shī, Xiàng-dōng (2009) “Cóng xì-tǒng hé jié-gòu de guān-diăn kàn Hàn-yǔ shàng-gǔ-yīn yán-jiū”. Nán-kāi yǔ-yán xué-kān 13 (2009, 1), 15-26. 
Shī, Xiàng-dōng (2012) “Luè lùn shàng-gǔ-yīn yán-jiū zhōng-de jǐ gè wèn-ti'. Bó-hăi dà-xué xué-bào (zhé-xué-shè-huì-kē-xué-băn) 2012, 6, 19-24.

Shī, Xiàng-dōng (2015) “Guān-yú Hàn-Zàng yīn-guǐ wèn-tí de zài sī-kăo zhī-ȳ̄”. Nán-kāi yǔ-yán xuékān $25(2015,1), 1-10$.

Shī, Xiàng-dōng (2017) "Guān-yú Hàn-yǔ shàng-gǔ yùn-bù yí-bù-yì-yuán-yīn yǔ yí-bù-duō-yuán-yīn wèn-tí de wǒ-jiàn”. Yǔ-yán lì-shĭ lùn-cóng 10, 1-23.

Shí, Bīng (2003) "Yè lùn jiè-cí yú de qǔ-yuán hé fā-zhăn". Zhōng-guó yǔ-wén 2003, 4, 343-347.

Shǐ, Cún-zhí (1985) Hàn-yǔ yīn-yùn-xué gài-yào. Hefei: Anhui Education Press.

Starostin, Sergej A. (1989) Rekonstrukcija drevnekitajskoj fonologičeskoj sistemy. Moskva: Nauka. [Chinese translation (2010) Sī Ā Sī-tă-luó-sī-jīn (zhù); Lín Hăi-yīng, Wáng Chōng (yì) Gŭdài Hàn-yǔ yīn-xì de gòu-nǐ. Shanghai: Shanghai Education Press; Chinese translation (2012) C.A.Sī-tă-luó-sī-jīng (zhù); Zhāng Xīng-yà (yì) Gǔ-Hàn-yǔ yīn-xì de gòu-nǔ. Beijing: Peking University Press.]

Sūn, Hóng-kāi (2006) "Hàn-Zàng-yǔ yán-jiū zhōng-de yì-xiē wèn-ti'”. Yǔ-yán kē-xué 5, 1, 49-51.

Sūn, Hóng-kāi (2007) "Hàn-Zàng-yǔ yán-jiū fāng-fã zhī wǒ-jiàn”. Yǔ-yán kē-xué 6, 6, 60-61.

Sūn, Hóng-kāi (2009) "Hàn-Zàng-yǔ yán-jiū de lì-shǐ yǔ xiàn-zhuàng (jié-xuăn)". Hàn-zì wén-huà 2009, 4, 11-12.

Sūn, Hóng-kāi (2011) "Hàn-Zàng yǔ-xì lì-shǐ lèi-xíng-xué yán-jiū zhōng-de yì-xie wén-tí”. Yǔ-yán yán-jiū 31, 1, 113-120.

Sūn, Hóng-kāi (2015) “Qián-zhuì, qián-zhì fǔ-yīn hái shì 2-zhě jiān ér yǒu zhī”. Yún-nán shī-fàn dà-xué xué-bào (zhé-xué-shè-huì-kē-xué-băn) 47, 2, 13-17.

Sūn, Hóng-wěi (2019) "Bái Yī-píng wēi-bù wén-bù guī-zì jí zài fēn-lèi shāng-què”. Zhōng-guó yǔ-yánxué 9, 1-14.

Sūn, Qiáng; Léi, Táng-xún (2019) "Hàn-yǔ gǔ-ȳ̄n-xué de dāng-dài lùn-zhēng jí wèi-lái zǒu-xiàng”. Shè-huì kē-xué zhàn-xiàn 2019, 7, 164-180.

Sūn, Yù-wén (2000) Hàn-yŭ biàn-diào gòu-cí yán-jiū. Beijing: Peking University Press. [(2007) (zēngdìng-běn). Beijing: The Commercial Press.]

Sūn, Yù-wén (2002) “Hàn-yǔ lì-shĩ yīn-yùn-xué shàng-gǔ-piān zhǐ wù”. Gǔ-Hàn-yŭ yán-jiū 2002, 4. 13-24.

Sūn, Yù-wén (2005) "Shàng-gǔ-yīn gòu-nǐ de jiăn-yàn biāo-zhǔn wèn-tí”. Yǔ-yán-xué lùn-cóng 31, 104-148.

Sūn, Yù-wén (2005-2006) "Shì lùn gēn míng-mǔ xié-shēng de xiăo-mǔ-zì de yǔ-yīn yăn-biàn". GŭHàn-yǔ yán-jiū 2005, 1, 2-8 and Hú-běi dà-xué xué-bào (zhé-xué-shè-huì-kē-xué-băn) 2006, 5, 535-538.

Sūn, Yù-wén (2007) "Shàng-gǔ-Hàn-yǔ cí-zhuì gòu-nǐ xī-píng”. Jiāng-hàn dà-xué xué-bào (rén-wénkē-xué-băn) 26, 3, 39-46 and 26, 4, 68-75.

Sūn, Yù-wén (2008a) "Hàn-yǔ shǐ yán-jiū zhōng-de kăo-zhèng yǔ yùn-yòng”. Zhōng-guó yīn-yùn-xué: Zhōng-guó yīn-yùn-xué yán-jiū-huì Nán-jīng yán-tăo-huì lùn-wén-jí2006·, 15-30. Nanjing: Nanjing University Press.

Sūn, Yù-wén (2008b) "Hàn-Zàng zhū yǔ-yán cí-huì bǐ-jiào de cí-yì duì-yìng wèn-tí". Zhōng-guó yǔyán-xué 1, 130-141.

Sūn, Yù-wén (2010) “Xié-shēng xì-liè yǔ shàng-gǔ-yīn”. Zhōng-guó yǔ-yán-xué 4, 1-23.

Sūn, Yù-wén (2014) “2-děng shēng-mǔ de shàng-gǔ-yīn gòu-nǐ wèn-tí”. Guó-xuéxué-kān 2014, 1, 119-128.

Sūn, Yù-wén (2018) “Cóng xié-shēng chéng-jì hé shēng-fú yì-dú kàn băi nián lái de shàng-gǔ fù-fǔ-ȳ̄n gòu-nǐ”. Mín-shú diăn-jí wén-zì yán-jiū 21 (2018), 1, 16-34.

Táng, Zuò-fān (1959) Hàn-yǔ yīn-yùn-xué cháng-shí. Shanghai: Shanghai Education Press. [Beijing: The Commercial Press, 2018.] 
Táng, Zuò-fān (1987) Yìn-yùn-xué jiào-chéng. Beijing: Peking University Press. [(1991) (dì-2-băn); (2002) (dì-3-băn); (2013) (dì-4-băn); (2016) (dì-5-băn)]

Táng, Zuò-fān (2003) “Wáng Lì xiān-shēng de xié-shēng-shuō”. Yǔ-yán-xué lùn-cóng 28, 1-22.

Wàn, Xiàn-chū (2008) Yīn-yùn-xué yào-luè. Wuhan: Wuhan University Press. [(2012) (dì-2-băn)]

Wāng, Shòu-mín; Pān, Wén-guó (1992) Hàn-yǔ yīn-yùn-xué y̌̌n-lùn. Shanghai: East China Normal University Press.

Wáng, Hóng-zhì (2019) “Guān-yú shàng-gǔ-Hàn-yŭ -r-yùn-wěi gòu-nǐ de Hàn-yǔ wén-xiàn zhèng-jù de zài jiăn-tăo”. Zhōng-guó yǔ-wén 2019, 2, 182-191.

Wáng, Lì (1948) “Hàn-Yuè-yǔ yán-jiū”. Lìng-nán xué-bào 9, 1, 1-96.

Wáng, Lì (1957) Hàn-yǔ sȟ găo. Beijing: Sciences Press. [(1958) (dì-2-băn); (1980) (xiū-dìng-běn) Beijing: Zhonghua Book Company]

Wáng, Lì (1963) Hàn-yǔ yīn-yùn. Beijing: Zhonghua Book Company.

Wáng, Lì (1964) “Xiān-Qín gǔ-yùn nǐ-cè wèn-tî”. Běi-jīng dà-xuéxué-bào (rén-wén kē-xué) 1964, 5, 41-62.

Wáng, Lì (1980a) Shī-jīng yùn dú. Shanghai: Shanghai Press of Classics.

Wáng, Lì (1980b) Chǔ-cí yùn dú. Shanghai: Shanghai Press of Classics.

Wáng, Lì (1985) Hàn-yǔ yǔ-yīn shǐ. Beijing: China Social Sciences Press.

Wáng, Níng; Huáng, Yì-qīng (2005) "Hàn-yǔ lì-shǐ yīn-yùn-xué yào zūn-zhòng lì-shǐ zūn-zhòng shìshí zūn-zhòng kē-xué”. Xué-shù-jiè 2005, 1, 124-138.

Wáng, Níng (2018) “Qī-dài fù-fǔ-yīn-shuō de lùn-zhèng jì-xù shēn-huà". Mín-shú diăn-jí wén-zì yánjiū $21(2018,1), 1-3$.

Wáng, Wéi-mín (2009) "Bó Zhèng-zhāng Shàng-fāng shàng-gǔ yí-bù-duō-yuán-yīn de lǐ-lùn jī-chǔ". Shān-xī dà-xué xué-bào (zhé-xué-shè-huì-kē-xué-băn) 32, 3, 57-61.

Wáng, Wéi-mín (2010) "Zhèng-zhāng Shàng-fāng yǔ Bái Yî-píng lí-xī shàng-gǔ yùn-bù zhī bǐ-jiào yán-jiū”. Yǔ-yán-xué lùn-cóng 42, 326-340.

Wáng, Wéi-mín; Zhāng, Chǔ (2009) "Zhèng-zhāng Shàng-fāng shàng-gǔ-yīn-xì què-dìng yuán-yīn yīn-wèi de fāng-fă shāng-què”. Nán-jīng shè-hui kē-xué 2009, 6, 122-128.

Xiàng, Bó-lín [= Jacques, Guillaume]; Chén, Zhēn (2004) "Chá-băo-huà de chóng-dié xíng-shì". Mínzú yǔ-wén 2004, 6, 12-18.

Xiàng, Xiăo-lù (2018) "Bái Ȳi-píng Shā-jiā-ěr shàng-gǔ-Hàn-yǔ gòu-nǐ xīn-lùn ruò-gān lì-zhèng shāng-què". Xī-yù lì-shǐ yǔ-yán yán-jiū jí-kān 10, 409-420.

Xú, Cóng-quán (2014) “Zhī-wēi fēn-bù wèn-tí yán-jiū”. Zhōng-guó Yǔ-yán-xué 7, 34-53.

Xuē, Fèng-shēng (2003) “Zhōng-guó yīn-yùn-xué de xìng-zhì yŭ mù-dì”. Gŭ-Hàn-yŭ yán-jiū 2003, 2, 2 -7.

Yahkontov, S. E. [= Jaxontov, Sergej E.] (1960) "Consonant combinations in Archaic Chinese". XXV International Congress of Orientalists: papers presented by the USSR delegation. Moscow: Oriental Literature Publishing House.

Yáng, Jiàn-qiáo (1996) Hàn-yǔ xiàn-dài yīn-yùn-xué. Shanghai: Fudan University Press. [(2012) (dì2-băn xiū-dìng-běn)]

Yáng, Jiàn-qiáo (2005) Hàn-yǔ yīn-yùn-xué jiăng-yì. Shanghai: Fudan University Press.

Yáng, Jiàn-qiáo (2006) “Yì-shēng-zhī-zhuăn yǔ tóng-yuán-cí yán-jiū”. Yǔ-yán yán-jiū jí-kān 3 (2006), 188-201.

Zēng, Róng-fén (2009) “Méi Zǔ-lín Zhōng-guó yǔ-yán-xué de chuán-tǒng hé chuàng-xīn dú-hòu-găn”. Yìn-yùn-xué fāng-fă-lùn tăo-lùn-jí, 218-233. Beijing: The Commercial Press.

Zhang, Shuya; Jacques, Guillaume; Lai, Yunfan (2019) "A study of cognates between Gyalrong languages and Old Chinese". Voprosy jazykovogo rodstva / Journal of Language Relationship $17,1,73-92$. 
Zhāng, Měng (2004) “Guān-yú xiăo-yă zhēng-yuè zhōng de xùn-gǔ wèn-ti'”. Gǔ-Hàn-yǔ yán-jiū 2004, $1,17-19$.

Zhāng, Mín-quán (2012) "Hàn-Zàng tóng-yuán jiă-shuō yǔ gǔ-ȳ̄n yán-jiū zhōng de ruò-gān wèn-tí". Shān-xī dà-xué xué-bào (zhé-xué-shè-huì-kē-xué băn) 2012, 9, 10-17.

Zhāng, Mín-quán (2013) “Cóng Qiāng-Zàng lì-shǐ kàn Hàn-Zàng tóng-yuán jiă-shuō yǔ gǔ-yīn yán-jiū wèn-tí”. Min-shú diăn-jí wén-zì yán-jiū 12 (2013, 2), 176-194.

Zhāng, Mín-quán (2014) "Lùn Hàn-Zàng tóng-yuán-cì de lì-shǐ bǐ-jiào yǔ Hàn-yǔ gǔ-yīn gòu-nǐ wèntỉ”. Zhōng-guó Yǔ-yán-xué 7, 1-13.

Zhāng, Shì-lù; Yáng, Jiàn-qiáo (1987) Yinn-yùn-xué rù-mén. Shanghai: Fudan University Press. [(2009) (dì-2-băn)]

Zhāng, Yán-chéng (2004) "Méi Zǔ-lín jiào-shòu yǔ-fă shǐ lùn-wén diăn-píng”. Gǔ-Hàn-yǔ yán-jiū 2004, 1, 3-12.

Zhāng, Yàn (2003) "Shăng-qù-2-shēng yuán-yú yùn-wěi shuō bù kě-xìn”. Yǔ-yán-xué lùn-cóng 28, 23-33.

Zhào, Tóng (2015) Hàn-yǔ yīn-yùn-xué gài-lùn. Beijing: China Renmin University Press.

Zhào, Tuán-yuán (2018) "Cóng shàng-gǔ wén-xiàn kàn Bái Yī-píng Shā-jiā-ěr shàng-gǔ-yīn gòu-nň”. X⿳亠丷⿵冂-yù lì-sȟ̌ yǔ-yán yán-jīu jí-kān 10, 421-431.

Zhào, Zhèn-duó (1990) Yìn-yùn-xué gài-yào. Chengdu: Bashu Book Company.

Zhèng, Niū (2012) "Shàng-gǔ yí-mǔ- hé xīn-mǔ-zì tè-shū xié-shēng guān-xì yán-jiū". Zhōng-guó yǔyán-xué 6, 35-61.

Zhèng, Wěi (2009) “Cóng Dòng-Tái-yǔ kàn Hàn-yǔ de fù-shēng-mǔ”. Mín-zú yǔ-wén 2009, 2, 50-56.

Zhèng, Wěi (2018) Yìn-yùn-xué: Fāng-fă hé shi-jiàn. Shanghai: Shanghai Press of Classics.

Zhengzhang, Shangfang [= Zhèng-zhāng, Shàng-fāng] (2000) The phonological system of Old Chinese, translated by Laurent Sagart. Paris: École des Hautes Études en Science Sociales, Centre de Recherches Linguistiques sur l'Asie Orientale.

Zhèng-zhāng, Shàng-fāng (1987) "Shàng-gǔ yùn-mǔ xì-tǒng hé 4-děng jiè-yīn shēng-diào de fā-yuán wèn-tí”. Wēn-zhōu shī-fàn xué-yuàn xué-bào (shè-huì-kē-xué-băn) 1987, 4, 67-90.

Zhèng-zhāng, Shàng-fāng (1992) "Qiē-yùn j-shēng-mǔ yǔ i-yùn-wěi de lái-yuán wèn-tí”. Jì-niàn Wáng Lì xiān-shēng 90-dàn-chén wén-jí, 160-179. Jinan: Shangdong Education Press.

Zhèng-zhāng, Shàng-fāng (2003a) Shàng-gǔ yīn-xì. Shanghai: Shanghai Education Press [(2013a) (dì-2-băn)]. Zhèng-zhāng, Shàng-fāng (2003b) "Hàn-yǔ yǔ qīn-shǔ yǔ-yán bř-jiào de fāng-fă wèn-tí ". Nán-kāi yǔyán xué-kān 2 (2003), 1-10.

Zhèng-zhāng, Shàng-fāng (2006) "Hàn Zàng liăng yǔ yùn-mǔ de yì-cháng duì-yìng”. Yǔ-yán yán-jiū 26, 2, 1-4.

Zhèng-zhāng, Shàng-făng (2007) "Shàng-gǔ Hàn-yǔ de yīn-jié yǔ shēng-mǔ de gòu-chéng". Nán-kāi yǔ-yán xué-kān 10 (2007, 2), 5-12.

Zhèng-zhāng, Shàng-fāng (2008a) "Měi-zì de guī-bù wèn-tí”. Yǔ-yán-xué lùn-cóng 38, 312-317.

Zhèng-zhāng, Shàng-fāng (2008b) "Lùn Hàn-yǔ Miáo-Yáo-yǔ shēng-mǔ zhōng liú-yīn $\mathrm{r}, 1$ de chóngjiàn jí gǔ-yīn gòu-nǐ piān-xiàng”. Dōng-fāng yǔ-yán-xué 4 (2008, 2), 57-62.

Zhèng-zhāng, Shàng-fāng (2012) "Gǔ-yīn-zì-biăo kān-wù 3 zhǒng (shàng)". Nán-kāi yǔr-yán xué-kān $20(2012,2), 129-165$.

Zhèng-zhāng, Shàng-fāng (2013b) "Jǐn dá Chén Xīn-xióng xiān-shēng duì Shī-jīng de gǔ-ȳ̄n-xué jiàzhí de shù-píng”. Chén Bó-yuán xiān-shēng wén-zì-yīn-yùn-xùn-gǔ-xué guó-jì xué-shù yán-tăohuì lùn-wén-jí. Nanyang: Nanyang Normal University.

Zhōu, Kè-yōng (2005) “Shì fù-fǔ-yīn shēng-mǔ hái shì duō-yīn-jié zì”. Dōng-yuè lùn-cóng 27, 6, 151-154. 
Zhōu, Shǒu-jìn (2005) "Hàn-yǔ lì-shǐ yīn-yùn-xué yán-jiū zhī biàn-wěi yǔ qiú-zhēn”. Gǔ-Hàn-yǔ yánjiū 2005, 2, 24-31.

Zhōu, Shǒu-jìn (2015) "Guān-yú dì-3-cì gǔ-yīn-xué dà-biàn-lùn de liăng diăn sī-kăo". Zhōng-guó yǔyán-xué 8, 45-57.

Zhōu, Zǔ-mò (1966) “Shī-jīng yùn-zì biăo”. In Zhōu Zǔ-mò, Wèn xué ji , 218-269. Beijing: Zhonghua Book Company.

Zhōu, Zǔ-xiáng (2003) Xìn-zhù yīn-yùn-xué. Shanghai: Shanghai Lexicon Press.

Zhū, Xiăo-nóng (2006) “Lì-shǐ yǔ-yán-xué de 5 xiàng jī-běn”. Dōng-fāng yǔ-yán-xué 1, 121-129.

Zhú, Jiā-níng (2017) "Băi nián lái de fù-shēng-mǔ yán-jiū". Hàn-yǔ sh ̌̌ yǔ Hàn-Zàng-yǔ yán-jiū 2 (2017, 2), 1-21.

Zhú, Jiā-níng (2018) “Fù-shēng-mǔ yán-jiū de fāng-fă hé jī-běn yuán-zé”. Mín-shú diăn-jí wén-zì yánjiū $21(2018,1), 4-15$.

Zhù, Mǐn-chè (2003) “Zài tán shǐ-chéng-shì (dòng-jié-shì) de chăn-shēng shí-dài”. Gǔ-Hàn-yǔ yán-jiū 2003, 3, 37-38. 
Appendix 1. Major monographic titles on Chinese historical phonology by the two sides

\begin{tabular}{|c|c|}
\hline The Sino-linguists' side & The descriptivists' side \\
\hline $\begin{array}{l}\text { OC reconstructions (7): Wáng L. [王力] } 1957 \\
\text { [1958, 1980], 1980a, 1980b; Guō X. [郭錫 } \\
\text { 良] 1986 [2010]; Chén F. [陳復華] \& Hé J. [ } \\
\text { 何九盈] 1987; Hé J. 1991; 1993-HZGJ (edited } \\
\text { by Lǐ Z. [李珍華] \& Zhōu C. [周長楫]) \| } \\
\text { Handbooks (25): Táng Z. [唐作藩] 1959 [2008], } \\
\text { 1987 [1991, 2002, 2013, 2016]; Wáng L. 1963 } \\
\text { [2003], 1985; Lǐ X. [李新鬼] 1979, } 1986 \text { (no } \\
\text { medial); Chén F. } 1983 \text { [2002]; Shǐ C. [史存 } \\
\text { 直] 1985; Hé J. 1988 [2010]; Zhào Z. [趙振 } \\
\text { 鐸] 1990; Wāng S. [汪壽明] \& Pān W.-g. [潘文 } \\
\text { 國] 1992; Chén R. [陳壬秋] 1995; Lǐ B. [李葆 } \\
\text { 嘉] 1998; Hú A. [胡安順] 1998, 2001 [2003]; } \\
\text { Liú L. [劉綸金金] 2001; Lín T. [林壽] \& Gěng Z. } \\
\text { [耿振生] 2004; Gěng Z. 2004; Lóng Z. [龍莊 } \\
\text { 偉] 2005; Lǐ W. [李無未] 2006; Liú X. [劉曉 } \\
\text { 南] 2007 [2016], 2011; Wàn X. [萬獻初] 2008; } \\
\text { Jiăn Q. [簡啟賢] 2013; Gěng Z. 2016 \|| Other } \\
\text { (4): Dīng Q. [丁啟陣] 2000, 2016; Páng G. [龐 } \\
\text { 光華] 2005 (monographs entitled “Refutation of } \\
\text { consonant clusters in OC”); Lǐ J. 2015 [李建强] } \\
\text { (monograph on refuting *-r- in OC”) }\end{array}$ & 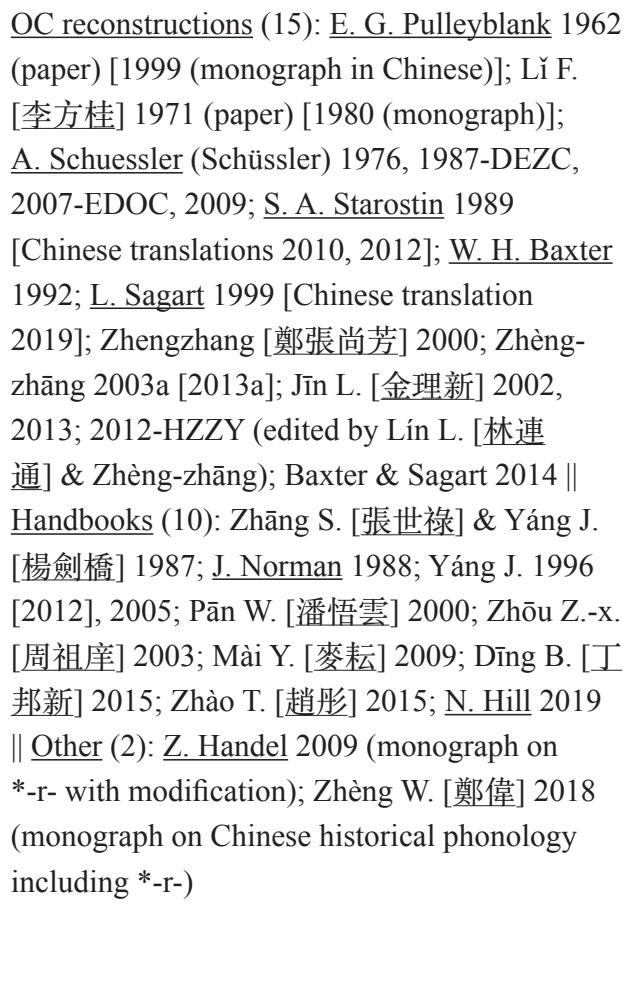 \\
\hline Titles: $7+25+4=36 . \underline{\text { Authors: } 26}$ & Titles: $15+10+2=27$. Authors: 20 \\
\hline
\end{tabular}


Appendix 2. Major Chinese papers on the intensive controversy by the two sides

\begin{tabular}{c} 
The Sino-linguists' side \\
\hline Guō X. [郭錫良] 2002 (re: Méi Z. 2002);
\end{tabular}
Sūn Y. [孫玉文] 2002 ( $\nabla$ Pān W. 2000); Chén X. [陳新雄] 2003, Lǔ G. [魯國堯] 2003, Huà X. [華學誠] \& Băi Y. [柏亞東] \& Wáng Z. [王 智群] \& Zhào Q. [趙奇棟] \& Zhèng D. [鄭東 珍] 2003, Xuē F. [薛鳳生] 2003, Guō X. 2003 (re: Méi Z. 2003); Zhù M. [祝敏徹] 2003, Dù C. [杜純梓] 2003a ( V Méi Z. 1991); Gěng Z. [耿 振生] 2003 ( $\nabla$ Pān W. 2000); Táng Z. [唐作藩] 2003 (re: Méi Z. 2002); Zhāng Y. [張雁] 2003 $(\boldsymbol{\nabla} *$-? and *-s), Lǐ X. [李香] $2003(\nabla *$-s); Dù C. 2003b (re: Dīng B. 2003); Zhāng Y.-c. [張延成] 2004 ( $\nabla$ Méi Z. 2000); Zhāng M. [張 猛] 2004 (re: Dǒng J. 2003); Huáng Y. [黄易 青] 2004 ( $\nabla$ Mei 1979 S-T comparisons); Hé J. [何九盈] 2004, 2005, Gěng Z. 2005 ( $\nabla$ PST); Hú J. [胡繼明] 2005 (re: Méi Z. 2002); Sūn Y. 2005 ( $\nabla$ Pān W. 2000), 2005-2006 ( $\boldsymbol{\nabla}$ *sm- and *hm-); Cài Y. [蔡永貴] 2005 ( $\boldsymbol{\nabla} *$ Cc-); Zhōu S. [周守晉] 2005 (re: Mài Y. 2003b); Guō X. 2005 (re: Shí B. 2003 and Méi Z. 2004, $\nabla$ this S-T comparison); Wáng N. [王寧] \& Huáng Y. 2005 (overview); Huáng Y. 2005 (on xiesheng series); Anonymous 2006 (intercession, call for ceasing); Lǐ K. [李開] 2006 (academic history of CHP); Dīng Q. [丁启陣] 2006, Lǐ J. [李建 强] 2007 ( $\boldsymbol{\nabla}$ *Cc-); Lǔ G. 2007 (methodology); Sūn Y. 2007 ( $\nabla$ affixes); Guō X. 2007a (re: Méi Z. 2006), 2007b (overview); Cū̄ Y. [崔彦] 2007 ( $\boldsymbol{\nabla}^{*}$-r-); Sūn Y. 2008a, Guō X. 2009 (re: Pān W. 2005); Gāo Y. [高永安] 2008 (re: Mă. 2006); Guō X. 2008 ( $\nabla$ PST); Sūn Y. 2008b ( $\nabla$ a few S-T comparisons); Chén X. 2008, Wáng W. [王為民] 2009, 2010, Wáng W. \& Zhāng C. [張楚] 2009 ( $\boldsymbol{\nabla} *$ T6V); Guō X. 2009, Chén X. 2009 (overview); Pān B. [潘柏年] 2009, Zēng R. [曾榮汾] 2009, Hé K. [何昆益] 2009, Lín Q. [林慶勳] 2009 (re: Méi Z. 2002); Chén G. [陳廣忠] 2009 ( $\boldsymbol{\nabla}^{*}$ Cc-); Lí X. [黎新宇] 2009 (re: Féng Z. 2008); Sūn Y. 2010 ( $\boldsymbol{\nabla} *$ Cc-); Guō
The descriptivists' side

MéiZ. [梅祖麟] 2002; 2003 (re: GuōX. 2002);

Jinn L. [金理新] 2003 (S-T comparisons, with disclamation of two comparisons); Zhèng-zhāng [鄭張尚芳] 2003b (methodology of external comparisons); Dīng B. 2003 [丁邦新] ( $\mathbf{\Delta}$ Méi Z. 1991); Mài Y. [麥耘] 2003a ( Pān W. 2000), 2003b (intercession); Dǒng J. [董建交] 2003 (re: Sūn Y. 2002); Shí B. [時兵] 2003, Méi Z. 2004 ( $\nabla$ Guō X. 1997, with a S-T comparison); Jin L. 2004 ( $\bullet$ sy- and *hy-); Jīn L. 2005a (on prefix *m-), 2005b (峦-s); Pān W. [潘悟雲] 2005a (re: Guō X. 2002 and Sūn Y. 2002); 2005b, Mài Y. 2005 (methodology); Huáng S. [黄樹先] 2005 (Chinese-Burmese comparisons); Chén Z. [陳忠 敏] 2005 (methodology); Méi Z. 2006 (confession and a new question); Zhèng-zhāng 2006 (methodology); Yáng J. [楊劍橋] 2006 ( $\Delta$ Méi Z. 2002 etc.); Mă. [J. A. Matisoff] 2006 (re: Hé J. 2004); Zhōu K. [周克庸] 2006 (re: Cài Y. 2004); Zhū X. [朱晓農] 2006 (methodology); Sūn H. [孫 宏開] 2006, 2007, Gōng H. [龚煌城] 2007, Mă. 2007, Shī X. 2007 [施向東] (\S-T); Méi Z. 2007 (on *gl-); Zhèng-zhāng 2007 ( $\bullet *$ Cc- etc.); Pān W. 2007, Luó Y. [羅永現] 2007 ( $\vee^{*}-1$ and *-r); Méi Z. 2008a ( $\bullet *$ Cc-), 2008b ( affix *s); Féng Z. [馮蒸] 2008 (overview); Zhèng-zhāng 2008a (re: Guō X. 2007a); 2008b ( ${ }^{*}$-r- etc.); Chén Z. 2009 (methodology); Féng Z. 2009a (academic history of S-T comparisons); Sūn H. 2009 ( $\bullet$ ST); Féng Z. 2009b, Shī X. 2009 ( $*$ Cc-); Zhèng W. [鄭偉] 2009 (external comparisons to *Cc-); Pān W. 2010 (methodology); Féng Z. 20102011 (academic history of CHP); Pān W. 2011 (methodology); Sūn H. 2011 (\S-T); Liú K. [劉] 琨] 2011 (on *Cc-); Féng Z. 2011 (methodology); Zhèng-zhāng 2012 ( $\nabla$ Guō X. 1986); Shī X. 2012 ( $*$ Cc- etc.); Chén B. [陳保亞] \& Wāng F. [汪鋒] 2012, Cuī J. [崔金明] 2012, 2013 (『ST); Cūi J. \& Liú K. 2013, Cū̄ J. 2015 ( $\bullet * C c-) ;$ Zhèng-zhāng 2013 (re: Chén X. 2008); Méi 
X. 2011 (re: Zhèng-zhāng 2008a); Páng G. [龐 光華] $2011(\boldsymbol{\nabla} *$-r or *-1); Zhāng M. [張民權] 2012, 2013, 2014 ( $\boldsymbol{\nabla}$ PST); Zhèng N. [鄭妞] 2012 ( $\boldsymbol{\nabla}^{*}$ sy- and *hy-); Huáng Y. 2013-2014 ( $\boldsymbol{\nabla}$ *kl-); Qú A. [篗靄堂] \& Jìn S. [勁松] * 2013 (S-T Sprachbund instead of language family); Xú C. [徐從權] 2013 ( $\boldsymbol{\nabla} *$ T6V); Sūn Y. 2014 ( $\boldsymbol{\nabla}^{*}$-r-); Guō X. 2014 (overview); Hé J. 2014-2015 (Hua-Yi instead of S-T); Zhōu S. 2015 (re: Féng Z. 2008); Lǐ J. 2017 ( $\boldsymbol{\nabla}$ *Cc-); Lǐ J.-j. [李鹃娟] 2017 (re: Zhèng-zhāng 2013); Hé J. 2017 (re: Mă. 2006); Chéng Y. [程悅] 2018, Gāo Y. 2018, Léi T. [雷瑭洵] 2018, Xiàng X. [向篟路] 2018, Zhào T.-y. [趙團員] 2018 ( $\nabla$ Baxter \& Sagart 2014); Wáng N. 2018 ( $\nabla *$ Cc-); Sūn Y. 2018 ( $\boldsymbol{\nabla}^{*}$ Cc-); Qí X. [齊晓 燕] 2018, Sūn H.-w. [孫洪偉] 2019 ( $\nabla$ Baxter \& Sagart 2014 and $\boldsymbol{\nabla} *$ T6V); Sūn Q. [孫强] \& Léi T. 2019 (overview and $\nabla$ Baxter \& Sagart 2014); Qiáo Q. [喬全生] 2020 (academic history of CHP)

Titles: 83. Authors: 52
Z. 2013, 2015 ( affix *s); Liú Q. [劉芹] 2014 ( $\bullet$ Cc-); Féng Z. 2014 ( $2012-H Z Z Y)$; Dài Q. [ 戴慶廈] 2015 ( $\vee$ S-T, different voice beside Hé 2014-2015); Shī X. 2015 (\S-T); Sūn H. 2015 (on *Cc-); Jīn L. 2016 (methodology); Shī X. 2017, Féng Z. 2017 ( *T6V); Zhú J. [竺家寧] 2017, 2018 ( $\vee$ *C-, different voice beside Wáng N. 2018 and Sūn Y. 2018); Mǎ K. [馬坤] 2017 (•Baxter \& Sagart 2014); Pān W. 2018 ( $\bullet *$ smand *hm-); Bái Y. [W. H. Baxter] \& Pān W. 2018 (•Baxter \& Sagart 2014); Wáng H. [王弘治] 2019 (confession on *-r, without disclamation)

Abbreviations: re: $=$ reply to; $\boldsymbol{\nabla}=$ refutation of; $\nabla=$ caveats to, or questions on; $\boldsymbol{\Delta}=$ defense of (with counterarguments); $\boldsymbol{\varphi}$ promotion of (without counterarguments); $\mathrm{Cc}-=$ consonant clusters as initial; $\mathrm{CHP}=$ Chinese historical phonology; PST = Sino-Tibetan as a certain language family; $\mathrm{S}-\mathrm{T}=$ Sino-Tibetan; $\mathrm{T} 6 \mathrm{~V}=$ the six vowels.

* These two authors are not Sino-linguists but con-Sino-Tibetan descriptivists. 


\section{Appendix 3. Chinese references in Sinograms}

$121-\mathrm{SW}=$ 許慎 (漢建光元年121) 說文解字. 雒陽. 徐鉉等 (校) (宋雍熙三年986). 東京.

543-YP = 顧野王 (梁大同九年543) 玉篇. 建康. [陳彭年等 (修)] (宋大中祥符六年1013) 大廣益會玉篇. 東京. 1008-GY = [陳彭年等 (修)] (宋大中祥符元年1008) 大宋重修廣韻. 東京.

$1161-Y J=$ 张麟之 (序) (宋紹興辛巳1161) 韻鏡. 臨安.

1993-HZGJ = 李珍華; 周長楫 (編撰) (1993) 漢字古今字音表. 北京: 中華書局.

2014-HZZY = 林连通; 郑张尚芳 (编撰) (2014) 汉字字音演变大字典. 南昌: 江西教育出版社.

(匿名)节于今 (2006) “建设创新型语言学”. 古汉语研究 2006, 1, 2-6.

白一平; 潘悟云 (2018) “上古音对谈实录”. 语言研究集刊 21 (2018, 2), 394-416.

蔡永贵 (2005) “复辅音声母: 一个并不可信的假说”. 宁夏大学学报(人文社会科学版) 27, 2, 5-11.

陈保亚; 汪锋 (2012) “汉语藏缅语同源的两个词汇有阶分布证据”. 云南师范大学学报(哲学社会科学版) 44, 5, 13-17.

陈复华 (1983) 汉语音韵学基础. 北京: 中国人民大学出版社. [(2002) 第2版修订本]

陈复华; 何九盈 (1987) 古韵通晓. 北京: 中国社会科学出版社.

陈壬秋 (1995) 汉语音韵学概要. 成都: 四川大学出版社.

陈新雄 (2003) “梅祖麟有中国特色的汉语历史音韵学讲辞质疑”. 语言研究 23, 1, 28-36.

陈新雄 (2008) “郑张尚芳诗经的古音学价值论述”. 中国语言学 1, 11-14.

陈新雄 (2009) “陈序”. 音韵学方法论讨论集, 4-6. 北京: 商务印书馆.

陈忠敏 (2005) “有关历史语言学的一些基本问题”. 语言研究 25, 3, 69-76.

程悦 (2018) “基于内证材料对上古汉语构拟新论宵藥分部的考察与讨论”. 湖北大学学报(哲学社会科学版) $45,1,155-164$.

崔金明 (2012) “试析汉藏比较对上古音研究的价值”. 西北民族大学学报(哲学社会科学版) 2012, 4, 184-188. 崔金明 (2013) “试析汉藏比较语言学的发展对上古音研究的价值”. 汉字文化 2013, 2, 54-57.

崔金明; 刘琨 (2013) “李方桂与郑张尚芳上古复辅音比较研究”. 西北民族大学学报(哲学社会科学版) 2013,2, $101-105$.

崔金明 (2015) “试析上古与鼻音结合的复辅音的拟音问题”. 语言科学 14, 2, 131-140.

崔彦 (2007) “上古二等r介音构拟小议”. 湖北大学学报(哲学社会科学版) 35, 4, 21-24.

戴庆厦 (2015) “汉藏语研究的四个困惑及其前景”. 民俗典籍文字研究 $16(2015,2), 33-39$.

丁邦新 (1978) “論上古音中帶1的複聲母”. 屈萬里先生七秩榮慶論文集, 601-617. 臺北: 聯經出版事業公司.

丁邦新 (1979) “上古漢語的音節結構”. 歷史語言研究所集刊 50, 4, 717-739.

丁邦新 (1981) “漢語聲調源於韻尾說之檢討”. 中央研究院國際漢學會議論文集:語言文字組, 267-287. 臺北: 中 央研究院.

丁邦新 (1979) “上古漢語的音節結構”. 歷史語言研究所集刊 50, 4, 717-739.

丁邦新 (1981) “漢語聲調源於韻尾說之檢討”. 中央研究院國際漢學會議論文集:語言文字組, 267-287. 臺北: 中 央研究院.

丁邦新 (2003) “评梅祖麟事件”. 南开语言学刊 2 (2003), 131-134.

丁邦新 (2015) 音䫓學講義. 北京: 北京大學出版社.

丁启阵 (2000) 论古无复辅音声母. 澳门: 澳门语言学会.

丁启阵 (2005) “复辅音说的一些问题”. 语言教学与研究 2006, 5, 7-14.

丁启阵 (2016) 汉语复辅音说辨证. 北京: 中华书局.

董建交 (2003) “关于正月及其他”. 古汉语研究 2003, 4, 20-24.

杜纯梓 (2003a) “对动补结构产生于六朝说之献疑”. 语文研究 2003, 4, 32-36.

杜纯梓 (2003b) “对杀和死形式标志确立与应省略分析. 古汉语研究 2003, 4, 2-12.

冯蒸 (2008) “第三次古音学大辩论”. 汉字文化 2008, 4, 7-23.

冯蒸 (2009a) “汉藏语比较语言学重要论著述评与初步研究”. 汉字文化 2009, 1, 20-47.

冯蒸 (2009b) “论构拟上古复声母的原则与方法”. 汉字文化 2009, 5, 55-56.

冯蒸 (2010-2011) “二十世纪汉语历史音韵研究的一百项新发现与新进展”. 汉字文化 2010, 5, 5-19+6, 7-25 $+2011,1,40-44$.

冯蒸 (2011) “论古汉语和藏语同源词比较的音韵框架模式”. 汉字文化 2011, 6, 43-50.

冯蒸 (2014) “汉语字典古音标注的重大突破”. 汉字文化 2014, 4, 91-93.

冯蒸 (2017). “关于郑张尚芳白一平沙加尔和斯塔罗斯金三家上古音体系中的所谓一部多元音问题”. 南阳师 范学院学报(社会科学版) 16, 4, 1-13. 
高晶一 (2008) 汉语与北欧语言. 北京: 中国社会科学出版社.

高晶一 (2014) “汉语与乌拉尔语言同源关系概论”. 张维佳 (主编), 地域文化与中国语言, 36-90. 北京: 商务印书馆.

高永安 (2008) “是原则之争还是中西之争”. 湖北大学学报(哲学社会科学版) 35, 2, 64-69.

高永安 (2018) “談白一平沙加爾上古音體系的几個問題”. 西域歷史語言研究集刊 10, 391-396.

耿振生 (2003) “论谐声原则”. 语言科学 2, 5, 10-28.

耿振生 (2004) 20世纪汉语音韵学方法论. 北京: 北京大学出版社.

耿振生 (2005) “汉语音韵史与汉藏语的历史比较”. 湖北大学学报(哲学社会科学版) 32, 1, 81-88.

耿振生 (2016) 音韵学研究方法导论. 北京: 北京大学出版社.

龚煌城 (2006) “西方的历史比较语言学与汉藏语比较研究”. 语言学论丛 35, 280-295.

郭錫良 (1986) 漢字古音手册. 北京: 北京大學出版社.

郭锡良 (1997) “介词于的起源和发展”. 中国语文 1997, 2, 131-138.

郭锡良 (2002) “历史音韵学研究中的几个问题”. 古汉语研究 2002, 3, 2-9.

郭锡良 (2003) “音韵问题答梅祖麟”. 古汉语研究 2003, 3, 2-17.

郭锡良 (2005) “汉语介词于起源于汉藏语说商榷”. 中国语文 2005, 4, 341-345.

郭锡良 (2007a) “美字能归入微部吗? ”. 语言学论丛 35, 296-302.

郭锡良 (2007b) “淹博识断精审”. 湖北大学学报(哲学社会科学版) 34, 4, 17-18.

郭锡良 (2008) “汉藏诸语言比较研究刍议”. 中国语言学 1, 1-10.

郭锡良 (2009) “郭序”. 音韵学方法论讨论集, 1-3. 北京: 商务印书馆.

郭錫良 (2010) 漢字古音手册(增訂本). 北京: 商務印書館.

郭锡良 (2011) “再谈美字能归入微部? ”. 中国语言学 5, 1-6.

郭锡良 (2014) “谈谈古音学研究的十年论争”. 中国音韵学暨黄典诚学术思想国际学术研讨会论文集, 27-31.

厦门: 厦门大学出版社.

郭锡良 (2017) “也谈古汉语复辅音问题”. 郭锡良, 汉语研究存稿, 334-349. 北京: 中华书局.

何九盈 (1988) 古汉语音韵学述要. 杭州: 浙江古籍出版社. [(2010) 北京: 中华书局]

何九盈 (1991) 上古音. 北京: 商务印书馆.

何九盈 (2004) “汉语和亲属语言比较研究的基本原则”. 语言学论丛 29, 12-66.

何九盈 (2005) “所謂親屬語言的詞彙比較問題”. 董琨; 馮蒸 (主編), 音史新論: 慶祝邵榮芬先生八十壽辰學術 論文集, 30-34. 北京: 學苑出版社.

何九盈 (2014-2015) “重建华夷语系的理论和证据”. 民俗典籍文字研究 14 (2014, 2), 1-43 + 16 (2015, 2), 1-31. 何九盈 (2017) “重建华夷语系的理论和证据序”. 民俗典籍文字研究 19 (2017, 1), 2-17.

何昆益 (2009) “诸家质梅文述要”. 音韵学方法论讨论集, 234-248. 北京: 商务印书馆.

胡安顺 (1998) 汉语音韵学通论. 西安: 陕西人民教育出版社.

胡安顺 (2002) 音韵学通论. 北京: 中华书局 [(2003) (第2版)].

胡继明 (2005) “就王念孙广雅疏证研究同源词的方法与梅祖麟教授商榷”. 重庆三峡学院学报 21, 6, 60-67.

华学诚; 柏亚东; 王智群; 赵奇栋; 郑东珍 (2003) “就王念孙的同源词研究与梅祖麟教授商榷”. 古汉语研究 2003, 1, 8-13.

黄树先 (2005) “从核心词看汉缅语关系”. 语言科学 4, 3, 90-108.

黄易青 (2004) “论上古喉牙音向齿头音的演变及古明母音质”. 古汉语研究 2004, 1, 20-27.

黄易青 (2005) “论谐声的鉴别及声符的历史音变”. 古汉语研究 2005, 3, 22-29.

黄易青 (2013-2014) “从音义关系看中古来母字的上古音来源”. 民俗典籍文字研究 12 (2013, 2), 195-205 + 13

(2014, 1), 133-141.

简启贤 (2012) 音韵学教程增订本. 成都: 巴蜀书社.

金理新 (2002) 上古汉语音系. 合肥: 黄山书社.

金理新 (2003) “汉藏语的语音对应与语音相似”. 民族语文 2003, 3, 11-18.

金理新 (2004) “与晓母相关的一些谐声关系和晓母读音”. 温州师范学院学报(哲学社会科学版) 25, 6, 14-19.

金理新 (2005a) “上古汉语*m-前缀的意义”. 语言研究 25, 1, 73-77.

金理新 (2005b) “汉藏语的完成体后缀*-s”. 民族语文 2005, 2, 1-6.

金理新 (2013) 上古音略. 合肥: 黄山书社.

金理新 (2016) “古音构拟的一个问题”. 华中国学 2016, 1, 23-29.

赖云帆 (2013) “俄热话的辅音重叠”. 民族语文 2013, 6, 12-18.

雷瑭洵 (2018) “上古漢語構擬新論音義關係指誤”. 西域歷史語言研究集刊 10,397-408.

黎新宇 (2009) “读冯蒸教授第3次古音学大辩论讲辞”. 中国语言学 3, 1-13. 
李葆嘉 (1990) “试论原始华夏语的历史背景”. 语言学通讯 1990, 1/2, 1-2.

李葆嘉 (1998) 当代中国音韵学. 广州: 广东教育出版社.

李方桂 (1971) “上古音研究”. 清華學報 新9, 1/2, 1-61 [(1980). 北京: 商務印書館].

李建强 (2007) “对复辅音学说的疑问”. 湖北大学学报(哲学社会科学版) 35, 2, 64-69.

李建强 (2015) 來母字及相關聲母字的上古音研究. 北京: 中國社會科學出版社.

李建强 (2017) “从黄㑆声韵略说看当前复声母问题的论争”. 长江学术 2017, 1, 115-120.

李鹃娟 (2017) “论上古韵部元音与入声韵尾的清浊”. 期䣋学院学报 27, 2, 46-51.

李开 (2006) “现代学术史关于古音学的三次大讨论”. 南开语言学刊 7 (2006.1), 11-20.

李香 (2003) “关于去声源于-s尾的若干证据的商榷”. 语言学论丛 28, 34-42.

李新鬼 (1979) 古音概说. 广州: 广东人民出版社.

李新鬼 (1986) 汉语音韵学. 北京: 北京出版社.

李无未 (2006) 汉语音韵学通论. 北京: 高等教育出版社.

林庆勋 (2009) “传什么给下一棒”. 音韵学方法论讨论集, 249-262. 北京: 商务印书馆.

林奉; 耿振生 (2004) 音韵学概要. 北京: 商务印书馆.

刘琨 (2011) “谐声字与上古复声母研究”. 西北工业大学学报(社会科学版) 31, 2, 81-84.

刘纶金 (2001) 音韵学基础教程. 北京: 中国社会科学出版社.

刘芹 (2014) “郑张尚芳上古汉语复声母体系研究”. 宁夏大学学报(人文社会科学版) 36, 4, 1-12.

刘晓南 (2007) 汉语音韵学研究教程. 北京: 北京大学出版社. [(2016) (第2版)]

刘晓南 (2011) 音韵学读本. 上海: 上海交通大学出版社.

龙庄伟 (2005) 汉语音韵学. 北京: 语文出版社.

鲁国尧 (2003) “论历史文献考证法与历史比较法的结合”. 古汉语研究 2003, 1, 1-7.

鲁国尧 (2007) “论汉语音韵学的研究方法和我的结合论”. 汉语学报 2007, 2, 2-10.

罗永现 (2007) “上古汉语的韵尾*-1与*-r”. 东方语言学 2, 177-184.

马蒂索夫 (2006) “历史语言学研究不是奥林匹克竞赛”. 语言学论丛 34, 346-359.

马蒂索夫 (2007) “汉藏语研究40年: 1968-2007”. 语言科学 3, 3, 22-24.

马坤 (2017) “历史比较下的上古汉语构拟”. 中国语文 2017, 4, 496-509.

麦耘 (2003a) “潘悟云上古汉语复辅音声母研究述评”. 南开语言学刊 2 (2003), 135-141.

麦耘 (2003b) “汉语历史音韵研究中若干问题之我见”. 古汉语研究 2003, 4, 13-19.

麦耘 (2005) “汉语史研究中的假设与证明”. 语言研究 25, 2, 7-15.

麥耘 (2009) 音韵學概論. 南京: 江蘇教育出版社.

梅祖麟 (1991) “从汉代的动杀动死来看动补结构的发展”. 语言学论丛 16, 112-136.

梅祖麟 (2000) 梅祖麟语言学论文集. 北京: 商务印书馆.

梅祖麟 (2002) “有中国特色的汉语历史音韵学”. Journal of Chinese Linguistics / 中国语言学报 30, 2, 211-240.

梅祖麟 (2003) “比较方法在中国, 1926-1998”. 语言研究 23, 1, 16-27.

梅祖麟 (2004) “介词于在甲骨文和汉藏语里的起源”. 中国语文 2004, 4, 323-332.

梅祖麟 (2006) “从楚简(美)字来看脂微两部的分野”. 语言学论丛 32, 173-192.

梅祖麟 (2007) “闽语與浴两字阳调h-声母的来源”. 方言 2007, 4, 289-295.

梅祖麟 (2008a) “甲骨文里的几个复辅音声母”. 中国语文 2008, 3, 195-207.

梅祖麟 (2008b) “上古汉语动词浊清别义的来源”. 民族语文 2008, 3, 3-20.

梅祖麟 (2013) “原始漢藏語動詞後緅*-s在上古漢語裏的遺跡”. 歷史語言研究 6, 1-10.

梅祖麟 (2015) “跋严学宭先生给古汉语复声母论文集(1998)写的序”. 语言研究 35, 3, 125-127.

潘柏年 (2009) “梅祖麟中国语言学的传统和创新商榷”. 音韵学方法论讨论集, 195-217. 北京: 商务印书馆.

潘悟云 (2000) 汉语历史音韵学. 上海: 上海教育出版社.

潘悟云 (2005a) “字書派與材料派”. 董琨; 馮蒸 (主編), 音史新論: 慶祝邵榮芬先生八十壽辰學術論文集, 368-

375. 北京: 學苑出版社.

潘悟云 (2005b) “汉语方言学与音韵学研究方向的前瞻”. 暨南学报(哲学社会科学版) 2005, 5, 104-107.

潘悟云 (2007) “上古汉语的韵尾*-1与*-r”. 民族语文 2007, 1, 9-17.

潘悟云 (2010) “历史层次分析的若干理论问题”. 语言研究 30, 2, 1-15.

潘悟云 (2011) “面向经验科学的第三代音韵学”. 语言研究 31, 1, 59-63.

潘悟云 (2018) “上古汉语鼻音考”. 民族语文 2018, 4, 3-9.

庞光华 (2005) 论汉语上古音无复辅音声母. 北京: 中国文史出版社. 
庞光华 (2011) “论上古音歌部不带[-r]或[-1]尾”. 中国语言学 5, 7-15.

蒲立本 (著), 潘悟云; 徐文堪 (译) (1999). 上古汉语的辅音系统. 北京: 中华书局.

齐晓燕 (2018) “从先秦韵文看白一平沙加尔对歌月元三部的再分部及构拟”. 语言研究 38, 4, 86-96.

乔全生 (2020) “中国音韵学研究70年”. 陕西师范大学学报(哲学社会科学版) 49, 1, 29-49.

㫿露堂; 劲松 (2013) “论汉藏语语言联盟”. 民族语文 2013, 5, 13-24.

沙加尔 (著), 龚群虎 (译) (2019) 上古汉语词根. 上海: 上海教育出版社.

施向东 (2000) 汉语和藏语同源体系的比较研究. 北京: 华语教学出版社.

施向东 (2007) “汉藏比较中的历史层次与借词问题”. 语言科学 6, 6, 54-59.

施向东 (2009) “从系统和结构的观点看汉语上古音研究”. 南开语言学刊 13 (2009, 1), 15-26.

施向东 (2012) “略论上古音研究中的几个问题”. 渤海大学学报(哲学社会科学版) 2012, 6, 19-24.

施向东 (2015) “关于汉藏音轨问题的再思考之一”. 南开语言学刊 25 (2015, 1), 1-10.

施向东 (2017) “关于汉语上古韵部一部一元音与一部多元音问题的我见”. 语言历史论丛 10, 1-23.

时兵 (2003) “也论介词于的起源和发展”. 中国语文 2003, 4, 343-347.

史存直 (1985) 汉语音韵学纲要. 合肥: 安徽教育出版社.

斯阿斯塔罗斯金 (著), 林海鹰; 王冲 (译) (2010) 古代汉语音系的构拟. 上海: 上海教育出版社.

C.A.斯塔罗思京 (著), 张兴亚 (译) (2012) 古汉语音系的构拟. 北京: 北京大学出版社.

孙宏开 (2006) “汉藏语研究中的一些问题”. 语言科学 5, 1, 49-51.

孙宏开 (2007) “汉藏语研究方法之我见”. 语言科学 6, 6, 60-61.

孙宏开 (2009) “汉藏语研究的历史与现状(节选)”. 汉字文化 2009, 4, 11-12.

孙宏开 (2011) “汉藏语系历史类型学研究中的一些问题”. 语言研究 31, 1, 113-120.

孙宏开 (2015) “前缀, 前置辅音还是二者兼而有之”. 云南师范大学学报(哲学社会科学版) 47, 2, 13-17.

孙强; 雷瑭洵 (2019) “汉语古音学的当代论争及未来走向”. 社会科学战线 2019, 7, 164-180.

孙洪伟 (2019) “白一平微物文部归字及再分类商榷”. 中国语言学 9, 1-14.

孙玉文 (2000) 汉语变调构词研究. 北京: 北京大学出版社. [(2007) (增订本). 北京: 商务印书馆.]

孙玉文 (2002) “汉语历史音韵学上古篇指误”. 古汉语研究 2002, 4. 13-24.

孙玉文 (2005) “上古音构拟的检验标准问题”. 语言学论丛 31, 104-148.

孙玉文 (2005-2006) “试论跟明母谐声的晓母字的语音演变”. 古汉语研究 2005, 1, 2-8 + 湖北大学学报(哲学 社会科学版) 2006, 5, 535-538.

孙玉文 (2007) “上古汉语词缀构拟析评”. 江汉大学学报(人文科学版) 26, 3, 39-46+26, 4, 68-75.

孙玉文 (2008a) “汉语史研究中材料的考证与运用”. 中国音韵学一中国音韵学研究会南京研讨会论文 集·2006, 15-30. 南京: 南京大学出版社.

孙玉文 (2008b) “汉藏诸语言词汇比较中的词义对应问题”. 中国语言学 1, 130-141.

孙玉文 (2010) “谐声系列与上古音”. 中国语言学 4, 1-23.

孙玉文 (2014) “二等聲母的上古音構擬問題”. 國學學刊 2014, 1, 119-128.

孙玉文 (2018) “从谐声层级和声符异读看百年来的上古复辅音构拟”. 民俗典籍文字研究 $21(2018,1), 16-34$.

唐作藩 (1959) 汉语音韵学常识. 上海: 上海教育出版社 [(2018) 北京: 商务印书馆].

唐作藩 (1987) 音韻學教程. 北京: 北京大學出版社 [(1991) (第2版); (2002) (第3版); 2013 (第4版); 2016: (第5版)].

唐作藩 (2003) “王力先生的谐声说”. 语言学论丛 28, 1-22.

万献初 (2008) 音韵学要略. 武汉: 武汉大学出版社. [(2012) (第2版)]

汪寿明; 潘文国 (1992) 汉语音韵学引论. 上海: 华东师范大学出版社.

王弘治 (2019) “关于上古汉语-r韵尾构拟的汉语文献证据的再检讨”. 中国语文 2019, 2, 182-191.

王力 (1948) “漢越語研究”. 嶺南學報 9, 1, 1-96.

王力 (1957) 漢語史稿. 北京: 科学出版社. [(1958) (第2版); (1980) (修訂本) 北京: 中華書局]

王力 (1963) 汉语音韵. 北京: 中华书局.

王力 (1964) “先秦古韵拟測問题”. 北京大学学报(人文科学) 1964, 5, 41-62.

王力 (1980a) 诗经韵读. 上海: 上海古籍出版社.

王力 (1980b) 楚辞韵读. 上海: 上海古籍出版社.

王力 (1985) 汉语语音史. 北京: 中国社会科学出版社.

王宁 (2018) “期待复辅音说的论证继续深化”. 民俗典籍文字研究 $21(2018,1), 1-3$.

王宁; 黄易青 (2005) “汉语历史音韵学要尊重历史尊重事实尊重科学”. 学术界 2005, 1, 124-138.

王为民 (2009) “驳郑张尚芳上古一部多元音的理论基础”. 山西大学学报(哲学社会科学版) 32, 3, 57-61. 
王为民 (2010) “郑张尚芳与白一平离析上古韵部之比较研究”. 语言学论丛 42, 326-340.

王为民; 张楚 (2009) “郑张尚芳上古音系确定元音音位的方法商榷”. 南京社会科学 2009, 6, 122-128.

向柏霖; 陈珍 (2004) “茶堡话的重叠形式”. 民族语文 2004, 6, 12-18.

向䈗路 (2018) “白一平、沙加爾上古漢語構擬新論若干例證商榷”. 西域歷史語言研究集刊 10, 409-420.

薛风生 (2003) “中国音韵学的性质与目的”. 古汉语研究 2003, 2, 2-7.

杨剑桥 (1996) 汉语现代音韵学. 上海: 复旦大学出版社 [(2012) (第2版修订本)].

杨剑桥 (2005) 汉语音韵学讲义. 上海: 复旦大学出版社.

杨剑桥 (2006) “一声之转与同源词研究”. 语言研究集刊 3 (2006), 188-201.

徐从权 (2014) “脂微分部问题研究”. 中国语言学 7, 34-53.

曾荣汾 (2009) “梅祖麟中国语言学的传统和创新读后感”. 音韵学方法论讨论集, 218-233. 北京: 商务印书馆. 张猛 (2004) “关于小雅正月中正月的训诂问题”. 古汉语研究 2004, 1, 17-19.

张民权 (2012) “汉藏同源假说与古音研究中的若干问题”. 山西大学学报(哲学社会科学版) 2012, 9, 10-17.

张民权 (2013) “从芫藏历史看汉藏语同源假说与古音研究问题”. 民俗典籍文字研究 12 (2013, 2), 176-194.

张民权 (2014) “论汉藏同源词的历史比较与汉语古音构拟问题”. 中国语言学 7, 1-13.

张世禄; 杨剑桥 (1987) 音韵学入门. 上海: 复旦大学出版社 [(2009) (第2版)].

张延成 (2004) “梅祖麟教授语法史论文点评”. 古汉语研究 2004, 1, 3-12.

张雁 (2003) “上去二声源于韵尾说不可信”. 语言学论丛 28, 23-33.

赵形 (2015) 汉语音韵学概论. 北京: 中国人民大学出版社.

趙團員 (2018) “從上古文獻看白一平沙加爾上古音構擬”. 西域歷史語言研究集刊 10, 421-431.

趙振鐸 (1990) 音韻學綱要. 成都: 巴蜀書社.

郑妞 (2012) “上古疑母和心晓母字特殊谐声关系研究”. 中国语言学 6, 35-61.

郑伟 (2009) “从侗台语看汉语的复声母”. 民族语文 2009, 2, 50-56.

郑伟 (2018) 音韵学:方法和实践. 上海: 上海古籍出版社.

郑张尚芳 (1987) “上古韵母系统和四等、介音、声调的发源问题”. 温州师范学院学报(社会科学版) 1987, 4, 67-90.

郑张尚芳 (1992) “切韵j声母与i韵尾的来源问题”. 纪念王力先生九十诞辰文集, 160-179. 济南: 山东教育出版社.

郑张尚芳 (2003a) 上古音系. 上海: 上海教育出版社. [(2013a) (第2版)]

郑张尚芳 (2003b) “汉语与亲属语言比较的方法问题”. 南开语言学刊 2 (2003a), 1-10.

郑张尚芳 (2006) “汉藏两语韵母的异常对应”. 语言研究 26, 2, 1-4.

郑张尚芳 (2007) “上古汉语的音节与声母的构成”. 南开语言学刊 10 (2007, 2), 5-12.

郑张尚芳 (2008a) “美字的归部问题”. 语言学论丛 38, 312-317.

郑张尚芳 (2008b) “论汉语苗瑶语声母中流音r、1的重建及古音构拟偏向”. 东方语言学 4 (2008, 2), 57-62.

郑张尚芳 (2012) “古音字表勘误三种(上)”. 南开语言学刊 20 (2012, 2), 129-165.

郑张尚芳 (2013b) “谨答陈新雄先生对诗经的古音学价值的述评”. 陈伯元先生文字音韵训诂学国际学术研讨 会论文集. 南阳: 南阳师范学院.

周克庸 (2005) “是复辅音声母还是多音节字”. 东岳论丛 27, 6, 151-154.

周守晋 (2005) “汉语历史音韵研究之辨伪与求真”. 古汉语研究 2005, 2, 24-31.

周守晋 (2015) “关于第三次古音学大辩论的两点思考”. 中国语言学 8, 45-57.

周祖謨 (1966) “詩經韻字表”. 周祖謨, 問學集. 218-269. 北京: 中華書局.

周祖庠 (2003) 新著音韵学. 上海: 上海辞书出版社.

朱晓农 (2006) “历史语言学的五项基本”. 东方语言学 1, 121-129.

竺家宁 (2017) “百年来的复声母研究”. 汉语史与汉藏语研究 2 (2017.2), 1-21.

竺家宁 (2018) “复声母研究的方法和基本原则”. 民俗典籍文字研究 21 (2018, 1), 4-15.

祝敏彻 (2003) “再谈使成式(动结式)的产生时代”. 古汉语研究 2003, 3, 37-38. 